


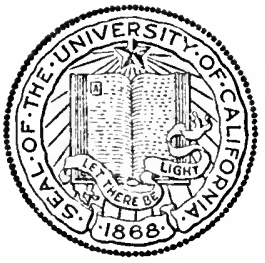

THE LIBRARY OF

THE UNIVERSITY OF CALIFORNIA LOS ANGELES

FROM THE LIBRARY OF

ERNEST CARROLL MOORE 


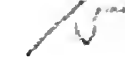




Digitized by the Internet Archive in 2007 with funding from Microsoft Corporation 
DOCUMENTS ILLUSTRATING

ELIZABETHAN POETRY 


\section{THE ENGLISH LIBRARY}

Fcap. 8vo, blue cloth extra, gilt tops.

The Folk and their Word-Lore. An Essay on Popular Etymologies. By Dr. A. SMYThe Palmer.

On the Study of Words. By Archbishop R. C. TRENCH. With Notes and Index by Dr. A. Smythe Palmer.

English Past and Present. By Archbishop TrENCH. With Notes and Index by Dr. $A$. Smythe Palmer.

Proverbs and their Lessons. By Archbishop TRENCH. With Notes, Bibliography, and Index by Dr. A. Smythe Palmer.

Punctuation: Its Principles and Prac. tice. By T. F. Husband, M.A.

How to Read English Literature. By laurie Magnus, M.A. Part I.-Chaucer to Milton. [Ready.] Part II.-Dryden, to TennysoN. [Oct., 1906.]

Documents Illustrating Elizabethan Poetry. By Sir Philip Sidney, G. Puttenham, and W. Webbe. Edited by Lavie MagNUS, M.A.

Others to follow. 


\section{Documents Illustrating}

\section{Elizabethan Poetry}

BY

SIR PHILIP SIDNEY, GEORGE PUTTENHAM AND WILLIAM WEBBE

EDITED BY

LAURIE MAGNUS, M.A.

A uthor of "Introduction to Poetry," etc.

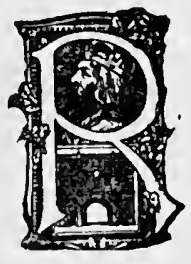

LONDON

GEORGE ROUTLEDGE \& SONS LTI)

New York : E. P. DUTTON \& CO 



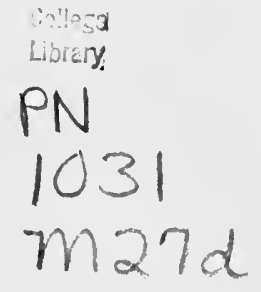

\section{PREFACE}

These Elizabethan Discourses on the art of poetry by Sidney, Puttenham, and Webbe are reprinted from Professor Arber's texts. I have modernized the spelling throughout. Puttenham's treatise comprises three books, i. of Poets and Poesie, ii. of Proportion, iii. of Ornament. I have reproduced only Bk.i. and Bk. iii., ch.4 (Of Language), which I have inserted as an introduction to $\mathrm{Bk}$. i., given in full with the exception of certain passages in chapter 26. Webbe's Discourse, as reproduced here, is complete as far as it goes, but I have omitted the sections dealing with matter and form and with Horace's canons.

The scope and purpose of the documents are explained in the Introduction and Notes.

L. M.

LoNDON, March, rgo6. 



\section{CONTENTS}

HAGE

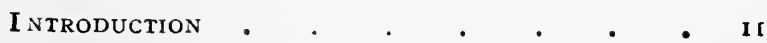

Sir Philip Sidney-

An Apology for Poetry . . . . 33

George Puttenham-

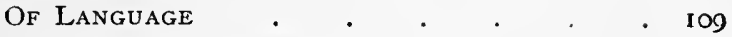

Of Poets and Poesy . . . . . I I 7

WiLliaM WEBBE-

A Discourse of English Poetry . . 197 



\section{INTRODUCTION}

THE almost simultaneous appearance of three critical treatises on poetry in the last quarter of the sixteenth century was not altogether fortuitous. In August I 579 Stephen Gosson published a pamphlet called The School of Abuse. It aroused considerable discussion in the little coterie of young literary men who were then at or near the circle of Queen Elizabeth's Court. Edmund Spenser, who had entered his Shepherd's Calendar at Stationers' Hall in the December of that year, wrote about it to Gabriel Harvey, who, by virtue of his few more years and of his considerably more pedantic erudition, ruled a group of aspiring 'wits' in the University of Cambridge. Sir Philip Sidney, to whom, without his permission, The School of Abuse had been dedicated by Gosson, in a letter addressed in October 1580 to his brother Robert, afterwards Earl of Leicester, showed that his thoughts were partially preoccupied by the subject of poetic criticism, and in the following September he had completed the treatise entitled $A n A$ pology for Poetry which is included in this volume. It is clear from various pieces of evidence that Sidney's defence of the art of poetry was circulated in MS. among his friends, though it was not actually published until 1595, nine years after his death. Meanwhile in September 1586 a Discourse of English Poetry was entered at Stationers' Hall on behalf of William Webbe, and in November I 588 an entry was made by Thomas Orwyn of the printing of The Art 
of English Poesy in Three Books-the First of Poets and Poesy, the Second of Proportion, and the Third of Ornament. This volume, transferred in I 589 to Richard Feild, by whom it was published in that year, with a dedication by Feild to Lord Burleigh, is ascribed on sufficient evidence to George Puttenham, who probably wrote it in or near the year $1585-$ a date which is determined on internal evidence. These, then, are the three treatises included in the present volume, and their close coincidence in time is clearly related to the Gosson publication. Accordingly, before we consider their contents and their authorship in detail, it will be well to examine the nature of this relationship and the time and circumstances of their production.

We are met at the outset by the remarkable fact that within the space of a very few years-possibly even a few months-Sidney and Spenser, two of the greatest names in the history of English literature, were joined with several of the minor writers of the same epoch, such as Harvey, Webbe, Gosson, Puttenham, and the like, in discussing from a more or less critical point of view, the art and craft of poetry. This unanimity is surprising in itself, and it becomes yet more surprising when we remark the unanimity of their point of view. They all agrec that English poetry has fallen not mercly upon a barren but upon an evil time. This argument is sustained among other places in the Tenth Eclogue of Spenser's Shepherd's Calendar where Cuddic, who stands as the pattern of the perfect poet, and who may represent Spenser himself, complains of the contempt in which his art is held, and of the lack of maintenance for his state and his studies. He illustrates this theme in a manner with which the prose treatises in this volume will shortly make us familiar, by contrasting the present discontent of the poet with the honour and esteem in which lie was held in past ages, from the 
time of the Greeks and Romans downwards. 'But ah !', he sings,

But ah! Mecaenas is yclad in claye, And great Augustus long ygoe is dead, And all the worthies liggen wrapt in leade, That matter made for Poets on to play : For ever, who in derring doe were dreade, The loftie verse of hem was loved aye. ... .

And if that any buddes of Poesie, Yet of the old stocke, gan to shoote agayne, Or it mens follies mote be forst to fayne, And rolle with rest in rymes of rybaudrye ; Or, as it sprong, it wither must agayne : Tom Piper makes us better melodie.

In the notes and commentary supplied liberally by Edward Kirke to these eclogues of Spenser we are told that Spenser had written a discourse, presumably in prose, called The English Poet, and though there is no record of the publication of that treatise, we may fairly conjecture that it would have repeated at length the views suggested by Cuddie in this eclogue. A similar line of argument is taken by Sidney, Puttenham and Webbe, all of whom approach their subject in an apologetic tone. With a singular likeness of thought they make it clear to their readers that the practice of poetry has been clegraded from its ancient and honourable estate, which they illustrate by references-more or less exact and correct, according to the degree of learning attained by the several authorsto writers of antiquity, and they insist that this degradation of the art which they love and cultivate is not inherent in the nature of poetry, but is the result of some outside cause operating to its discredit. Thus, in a sense, they may all be said to fill the part of the advocatus diaboli and to be defending an unpopular cause against the popular attacks of those who see no good in it. Gosson, who agrees with these writers as to the evil state of English Poetry, differs from 
them in his attitude towards it. He leads the attacking party, and it is probably correct to say that his School of Abuse was the direct motive of the defences attempted by Sidney and Spenser, Puttenham and Webbe. It will, therefore, be appropriate to quote in this place a few passages from The School of Abuse in order to see the type and style of the arguments to which these writers hastened to reply in justification of the Muse :

We have infinite poets and pipers, and such peevish cattle among us in England, that live by merry begging, maintained by alms, and privily encroach upon every man's purse. But if they that are in authority, and have the sword in their hands to cut off abuses, should call an account to see how many Chirons, Terpandri, and Homers are here, they might cast the sum without pen or counters, and sit down with Racha to weep for her children, because they were not....

Consider with thyself, gentle reader, the old discipline of England, mark what we were before and what we are now : leave Rome a while, and cast thine eye back to thy predecessors, and tell me how wonderfully we have been changed since we were schooled with these abuses. Dion saith that Englishmen could suffer watching and labour, hunger and thirst, and bear of all storms with head and shoulders; they used slender weapons, went naked, and were good soldiers, they fed upon roots and barks of trees; they would stand up to the chin many days in marshes without victuals : and they had a kind of sustenance in time of need, of which if they had taken but the quantity of a bean, or the weight of a pease, they did neither gape after meat, nor long for the cup, a great while after. The men in valour not yielding to Scythia, the women in courage passing the Amazons. The exercise of both was shooting and darting, running and wrestling and trying such masteries, as either consisted in swiftness of feet, agility of body, strength of arms, or martial discipline. But the exercise that is now among us is banqueting, playing, piping, and dancing, and all such delights as may win us to pleasure, or rock us to sleep.

$\mathrm{Ob}$ what a wonderful change is this ? Our wrestlings at arms is turned to wallowing in ladies' laps, our courage to cowardice, our running to riot, our bows into bolles, and our darts to dishes. We have robbed Greece of 
gluttony, Italy of wantonness, Spain of pride, France of deceit, and Dutchland of quaffing.

Further, in these passages of invective, Gosson naturally quotes the so-called authority of Plato, who banished the poets from his ideal Republic, of Cicero, who at the opening of his Tusculan Questions discusses the abuses of the art, and of detached passages from other writers of antiquity, which he turns to his own purpose.

An obvious reference to these passages from Gosson will be found in Sidney's $A$ pology, p. 77 below.

But it is against the theatre especially, that Gosson's virulence was directed. $\mathrm{He}$ admits that some of the plays performed at the few London houses of that date are 'without rebuke', but he adds that these ' are as easily remembered as quickly reckoned ', and it is noticeable that one of those exceptions described as 'good plays, and sweet plays, and of all plays the best plays and most to be liked' is a drama of his own, entitled Catiline's Conspiracies. With these few, and perhaps not wholly impartial exceptions, Gosson's abuse of the stage is unrestrained. With singular temerity, considering how eager a patron of the theatre Queen Elizabeth became in later life, he appeals to her Majesty's influence and disposition in urging his plea :

We unworthy servants of so mild a Majesty, unnatural children of so good a mother, unthankful subjects of so loving a prince, wound her heart with abusing her lenity. . . How many times hath access to theatres been restrained, and how boldly again have we re-entered. - . In our assemblies at plays in London, you shall see such heaving and shooing, such itching and shouldering to sit by women; such care for their garments that they be not trod on; such eyes to their laps that no chips light in them; such pillows to their backs that they take no hurt. . . . Such ticking, such toying, such smiling, such winking, and such manning them home when the sports are ended, that it is a right comedy to mark their behaviour. 
Such then, briefly, was the case for the plaintiff, and in the treatises reprinted here we have the case for the defendants. It is interesting and instructive to ask how it happened that at a time when Shakespeare was a lad at Stratford, and a very few years before he came to London to seek his fortune on the stage, such language and such views could have been possible at all. In this context the year 1579 in which The School of Abuse was published is in a sense misleading, or, more correctly, the perspective of time leads us in retrospect to take too general a view of the events of the years preceding the rise of Marlowe and Shakespeare. Every year in this period is important when reviewed at a closer range of vision. We cannot remember too clearly that Gosson wrote his attack, and that Sidney and the others wrote their defences of poetry, before the fame of Spenser had been established, and before-however shortly before - the name of Shakespeare had been heard of outside of his native village. They wrote in the darkness-in the worst darkness immediately before the dawnwhich had gradually overgrown English literature since the days of Chaucer two centuries before. Our habit of speaking of the Elizabethan Age tends to lead us to overlook the fact that the reign of Elizabeth was divided into two different and quite distinct periods - that of preparation, and that of fulfilment.

The first period was the longer of the two. It extended from Elizabeth's accession in 1558 till the execution of Mary Stuart in February 1587. To these thirty years belonged the Act of Uniformity; the assassination of the Regent Moray, and the other incidents of the dreary romance woven round Mary's fascinating personality. In the same period there was published the Papal Bull of Pius V, declaring Elizabeth a heretic, and the foreign policy of this generation was marked by the harassing and piratical expeditions undertaken largely on their own respon- 
sibility by English seamen against Philip of Spain. A more definite tendency was given to these movements towards the end of the period by English intervention in the Netherlands, and by Drake's fine exploits in the West Indies and at Cadiz.

The second period began after Queen Mary's execution, and ended at the death of Elizabeth herself in 1603. The removal of the Scottish peril left England free to set her own house in order, while, at the same time, it opened the road to a more definite declaration of policy on the part of Spain. Mary's death loosened the bonds by which Philip's hands had been tied. No scruple now stood in his way to prevent him from making his attempt to conquer England in his own interests. So we come to the Spanish Armada in 1588, and about the same time we have to note the death of the Earl of Leicester, and the gradual advancement of Essex in Elizabeth's counsels, till in I 599-after Lord Burleigh's death-he was appointed to the command in Ireland. Noticeable too in the review of this period, and especially noticeable in connection with the swift succession of events after Queen Elizabeth's death, is the increase of the power of Parliament, with its victory over the Monopolies in I60I, and, in an allied sphore of national progress, we have to note the Poor Law of the same year. This growth of self-expression took another but a kindred form in the full flower of Elizabethan literature, culminating in Bacon's prose and Shakespeare's drama, and we have, further, to note that the period witnessed the close of the struggle between the two great Catholic powers, France and Spain, bringing France into the important position in the forefront of European nations which was to exert so strong an influence on the politics of the succeeding century.

Accordingly, in this nearer perspective, the year 1579 , in which the present state and the future prospects of English poetry were debated so seriously by its E.L. 
champions and its detractors, is seen to lie somewhat outside of the circumference of that brilliant circle which is described as the Age of Elizabeth. For the purpose of the critical studies included in this volume and of the sharp attack on the drama and on allied branches of poetry which Gosson-not unlike Plato in a similar period of poetical decadence at Athenshad advanced in his pamphlet, we have to reconstruct the Elizabethan Age without Marlowe, Spenser, Shakespeare, Bacon. We have to imagine ourselves back in the reign of Elizabeth before the Spanish Armada was launched, and before the hardy freebooters of the sea had derived from its defeat their first least glimmering of a sense of national responsibility, which should temper and refine their spirit of dogged patriotism. We have to conceive a cabinet of Queen Elizabeth without the sagacity of Lord Burleigh, and with Mary of Scotland still the centre of conspiracies which clouded the brightness of England's meridian. Such an effort of imagination is indispensable to the correct apprehension of such data of criticism as the following :

I have just cause to make a pitiful defence of poor Poetry, which from almost the highest estimation of learning is fallen to be the laughing stock of children. ... Now then go we to the most important imputations laid to the poor Poets for aught I can yet learn, they are these : first, that there being many other more fruitful knowledges, a man might better spend his time in them than in this. Secondly, that it is the mother of lies. Thirdly, that it is the Nurse of abuse, infecting us with many pestilent desires: with a Siren's sweetness drawing the mind to the Serpent's tale of sinful fancy.

Pp. 35 and 77 infra.

For, as well Poets as Poesy are despised, and the name become, of honourable infamous, subject to scorn and derision, and rather a reproach than a praise to any that useth it. 
Every one that can frame a Book of Rhyme, though for want of matter, it be but in commendations of copper noses or bottle ale, will catch at the Garland due to Poets: whose pottical poetical (I should say) heads, I would wish, at their worshipful commencements might, instead of Laurel, be gorgeously garnished with fair green barley, in token of their good affection of our English malt. . . I I scorn and spue out the rakehelly rout of our ragged Rhymers, (for so themselves use to hunt the Letter) which without learning boast, without judgment jangle, without reason rage and fume, as if some instinct of poetical spirit had newly ravished them, above the meanness of common capacity.

P. 220.

Without that effort it is impossible to realize the strength of the Puritan bias against the profligate habits and unmannerly excesses which had grown up round the early Elizabethan stage to the prejudice of such theatrical companies as existed in 1579 , and which Gosson denounced with all the fervour of a convert.

With this revised impression of the state of literature in England towards the close of the first period of Elizabeth's reign, it is now instructive to ascertain what were the signs in the literary horizon at that time. Chiefly there was a great casting about for an adequate and suitable prose style. Certain schoolmasters and divines had written prose works which more or less filled the gap stretching in English literature between the great names of Chaucer and Spenser, and there were certain literary miscellanies which performed the function of the reviews and magazines of to-day in providing a refuge for the stray pieces of original or critical writing which are produced in every age. But at this moment in our history, when politics were distracted by the Scottish and Spanish dangers and when the fortunes of England-hardly saved by the masterful policy of Henry VIII - were entrusted to the precarious keeping of successive favourites of the Queen, it is not a matter for 
surprise that the literary voices should have been ambiguous, and that no one in fact should have had anything particularly urgent to say. In these circumstances, the search for a prose-style was neither strenuous nor deliberate. There was a vague feeling, stimulated to energy at the universities, that England was likely to forfeit her share in the treasures of the Renaissance for lack of a serviceable language in which to represent them. 'Our vulgar', as Puttenham called it-the rude speech of Tudor England-was incompetent to express the thoughts or to reproduce the style of Plato, Cicero, Virgil, Ovid, and their continental disciples. Nor was it worthy of a great nation, gradually raising herself to a sense of her place in the sun, that the chief literary activity should be monopolized by a band of translators, even though it included men of such sterling merit as North, Phaer, Golding and Florio. Moreover, there was a vague stirring, moved to enthusiasm at the Court, due to the occupation of the throne by a clever, active, selfrespecting woman, whose sex contrasted with the associations of Henry VIII and his predecessors, and whose virgin isolation and self-assertion were so refreshing a change from the conscientious dubitations of Philip's wife, Mary Tudor. This stirring of a new chivalry and of a new sense of England's independence required a language to express it, and the double stimulus which came from the universities and the Court, produced a series of experiments, half serious, half fanciful, and almost entirely academic, towards the creation of a prose-style. It had to satisfy the needs of scholars at Oxford and Cambridge-needs which, in that close atmosphere of learning, were not without a tinge of pedantry-and it had to gratify the taste of the wits at Elizabeth's Court, who desired to sing the praises of their mistress in correct allegorical strains. The difficulty was that neither party had anything much to say. They were on the 
eve of a great impulse, but its direction had still to be ascertained. The enchantments of the Middle Ages were to break through a nation's awakening in the scholar poet Edmund Spenser. The invocation to character and conduct raised to their highest capacity was reserved for Marlowe and Shakespeare, and the courage to take all learning for his province was to be the dower of Francis Bacon. But in these earlier, vaguer days, before the country had defeated her foes, or had developed, however imperfectly, any common ideals, political, moral or social, such attempt at self-expression were tentative and isolated, and undirected to a definite end. They were diplomapieces, so to speak, the prize-exercises of clever students, which lacked the vivifying force of experience of the larger world. On the side of style and manner, they had their own distinct value in the history of English letters, but they were not very enduring contributions to national literature.

Thus, John Lyly, of Magdalen College, Oxford, seeking a place in the sun, or office in Elizabeth's Court, composed novels and plays for the entertainment of the Queen, and became incidentally the first English novelist, in the sense of the first writer to graft a plot on his moralizings, and the father of English comedy. How much he owed to The Golden Book or The Dial of Princes by Antonio de Guevara (1495-1545), the Spanish stylist, and confessor to Charles $\mathrm{V}$ of Spain, is a question which scholars are decidins in a diminishing scale of affirmation. Larger portions of the debt are 'written off' by successive inquirers, and the truth seems to be that euphuism in England existed before Euphues, and that Lyly's two volumes, Euphues: the Anatomy of Wit and Euphues and his England, were at once fruit and seed, the product and the cause of a movement towards artificial expression which the times and the Court required. The movement, as such, was short-lived. It enjoyed 
extravagant praise during its brief popularity, and its obvious mannerisms of alliteration, simple and compound, its far-fetched similes from the fauna and flora of the ancients, its affected apparatus of antithetical periods and so forth, were checked by the parodies to which they readily lent themselves when the dust of pedantry was disturbed by the fresh breezes of Elizabethan drama. But though the reign of the Euphuists was comparatively short, their indirect influence on English literature has been almost incalculable. Prose-fiction in the eighteenth and nineteenth centuries traces its descent through Lyly, and the characteristic marks of English prose-the short sentence and the paragraph-are derived from the innovations employed by the Tudor euphuists.

Thus again, Sir Philip Sidney, when he retired temporarily from Court, composed for the amusement of his sister a long, meandering romance called The Countess of Pembroke's Arcadia, into which he wove the dreams of action which he never realized in his life, and through which he expressed the ideal of chivalrous conduct which won him eternal fame in the fatal field of Zutphen. Arcadianism was not a new note in English letters, but Sidney's use of it was marked by a rigid adherence to classical models. When he writes in the Apology (p. 43 infra) that he 'dare not allow' the rustic language employed by Edmund Spenser in The Shepherd's Calendar, he rests his objection on the sacred authority of Theocritus and Virgil. The 'wit' of the writers of this period was a kind of cult of culture, and the rules and patterns by which they worked led to the formation of literary clubs and cliques with rival theories of salvation by style. Sidney's club was 'the Areopagus', the leading spirit in which was that of Gabriel Harvey, a scholar by taste and pedant by instinct, who enjoyed a contemporary reputation which posterity has not confirmed. The Arcadia was a reply to the demand 
for a prose-style at Court, but it is valuable to-day, not for its conscientious care to observe the pastoral canons, but for the testimony it affords to the high purpose of the writer who, more than any hero of action or letters, ' wore the white flower of a blameless life'. The pastoral vein was continued through Spenser and Milton, and has been used effectively in our day; but neither Lyly nor Sidney, despite their undoubted influence on the writers who succeeded them, solved the literary problem of 1579how to give adequate expression to the new England which was being developed on so many parallel lines of national progress. Before another quarter of a century had elapsed Hamlet and The Advancement of Learning were added to the heritage ; the Euphuist and Arcadians flourished before this revelation.

One conclusion of great moment arises out of the consideration of the experiments of this time. It is the emancipation of woman from the unnatural seclusion to which she had been relegated in the Middle Ages. Laura and Beatrice, so to speak, were taken down from their shrines, to the incalculable gainultimately - of society and manners, and incidentally of literature. Part of this movement was due to the sex and personality of the Sovereign, but a larger part is to be traced to the rejection of the Papal dominion, with its aesthetic cult of the Madonna and its false standards of womanhood, leading to all the good and evil of the old ascetic chivalry. The reform of social life which was thus brought about paved the way (or accompanied the evolution) of Parliamentary government and democratic institutions. Here we may note its beginnings in the two significant facts that Lyly addressed himself to ladies, and that the Arcadia was written for Mary Pembroke. It is noticeable, too, that Puttenham's treatise in this volume was expressly composed for the edification of Queen Elizabeth. 
The state of letters and learning at the time when these treatises were composed should now be fairly clear, and it remains briefly to characterize their authors and their contents.

Sidney is distinguished from Puttenham and Webbe by the fact that he was a man of letters as well as a compiler of books. No one can read the Apology without at once being struck by the fine literary flavour which his character imparted to his style. Take, for example, in the early pages of this essay his praise of the psalmist:

he showeth himself a passionate lover of that unspeakable and everlasting beauty to be seen by the eyes of the mind, only cleared by faith-

take his description of the poet who,

lifted up with the vigour of his own invention, doth grow in effect another nature.... So that he goeth hand in hand with Nature, not inclosed within the narrow warrant of her gifts, but freely ranging only within the zodiac of his own wit-

or his exaltation of the poets above the moral philosophers,

whom, methinketh, I see coming towards me with a sullen gravity, as though they could not abide vice by daylight, rudely clothed for to witness outwardly their contempt of outward things, with books in their hands against glory, whereto they set their names, sophistically speaking against subtlety, and angry with any man in whom they see the foul fault of anger: these men, casting largess as they go of Definitions, Divisions and Distinctions, with a scornful interrogative do soberly ask, whether it be possible to find any path so ready to lead a man to virtue as that which teacheth what virtue is;

and it will readily be seen that Philip Sidney was a thinker as well as a writer, and that he had made the highest use of his few years of active life. That life belongs to English history, and its brief and brilliant story of promise and performance need not be recited 
here in detail. He was born in 1554 , the heir to a great name, and was educated at Shrewsbury and Oxford. Before he was twenty he had visited France, Germany, and Italy, on private or diplomatic missions, and had formed friendship or acquaintance with men of the eminence of Camden, Essex, Languet, Tintoretto, Veronese. A year or two later William of Orange relaxed his traditional silence to speak in praise of the young Englishman who visited his Court, and Sidney on his return added to the circle of his friends Spenser, Hakluyt, Giordano Bruno, and other great men of the age. He was in the counsels of the Queen, though he fell for a time under her displeasure, and when he died from the effects of the wound he received at Zutphen in 1586 Spenser (in Astrophel), Ralegh, James VI, Drayton and Breton were among the two hundred poets who wrote verses to his memory. It is to be noted that none of his own writings was published in his lifetime. The Arcadia appeared in 1590, Astrophel and Stella in I59r, the Apology for Poetry in 1595, and his metrical version of the psalms in 1823. Thus, it is clear that he wrote for a small audience of critics and chiefly to satisfy himself. For in literature, as in active life, Sidney was modest by nature. Soldier, courtier and scholar, he typified in all he did the Horatian motto placed by Henry Olney on the title-page of the first edition of The Apology for Poetry - 'odi profanum vulgus, et arceo'.

Of Puttenham, George or Richard, for the authorship of the Art of English Poesy lies between two brothers, little or nothing definite is known. The Dictionary of National Biography inclines to ascribe the treatise to Richard, elder son of Robert Puttenham, a country gentleman; but Professor Arber argued that the most plausible claim to the authorship is that of George Puttenham, of whom little else is known except from the internal evidence of this treatise itself. Arber collected the evidence with great 
skill and ingenuity, but there is little to add to our previous knowledge of the fact that the first trace of the association of Puttenham's name with the $A v t$ of English Poesy is found in an MS. by one Edmund Bolton, entitled Hypercritica, which, though written in the reign of James I, was not published till 1722 . There the treatise is ascribed to one of 'Queen Elizabeth's gentlemen pensioners, Puttenham ', and beyond the bare fact of this ascription we still cannot go. Whether the treatise was written by Richard, or by George, or by neither, it is clear to the reader that it was composed with a view to winning the favour of Queen Elizabeth, to whom the author addresses himself thoughout, and it may probably be inferred from a passage in Chapter VIII (see note, p. I42) that Puttenham had an eye to the patronage of the Queen, or of one of her nobles, in composing his pamphlet. It is written throughout in an easy though by no means elevated style, and it displays a considerable amount of fairly well-digested learning, which is presented in a popular manner, without display. The Books of Proportion and of Ornament, which are not reprinted here, are of much inferior interest at the present day, and include a lengthy list of so-called 'auricular figures', such as zeugma, parenthesis, epithet, metaphor, onomatopœia, irony, allegory, hyperbole, climax, apostrophe, tautology-to select only the simplest and most familiar of the namesand so forth. From the references in this book to other works by the same author-references introduced perhaps not without a touch of the candidate marshalling his testimonials in applying for the patronage of his mistress-we gather that Puttenham -like so many scholars of his day before the subdivision of the fields of learning - was something of an antiquarian and a poet as well as a student of pure letters. His treatise is well worth careful perusal, not merely as one of the earliest of its kind in the 
English language, but also for its very fair summary of the various kinds of literature, and for its interesting criticism of the writer's contemporaries.

Of William Wcbbe we have also to state that very little is known authoritatively. He was a college friend of Edmund Spenser at Cambridge ; a graduate at St. John's College, and we learn from the dedication of this book, and from other sources, that he acted as tutor in the families of private gentlemen for some years. He belonged to the school of The Areopagus, which aimed at the naturalization of classical metres in English, and he was plainly a man of considerable intellect and attainments. His present book was evidently written while Webbe was under the spell of Spenser's Shepherd's Calendar, which had quite recently appeared with Edward Kirke's notes and critical apparatus. His admiration for this pastoral poem-which was only acknowledged as Spenser's after his death-does great credit to his discernment, and raises his treatise at once to a high level of criticism. His rapid survey of English poetry, up to and including the writers of his own time, is particularly interesting, and he went on from that point to an elaborate comparison of Thomas Phaer's translation of the Eneid with the original text of Virgil. As this great Elizabethan work has been superseded today we have not reproduced Webbe's claborate criticism, nor have we reprinted his disquisition on the matter or form of English poetry, which included a criticism of the different sorts of verse employed in The Shepherd's Calendar. Wcbbe translated Hobbinol's song in that poem into sapphics, and the first two eclogues of Virgil into English hexameters, thus performing a pious office appropriate to his membership of 'The Areopagus', but of no value to modern readers. His treatise concluded with an appendix containing all the canons of poetry prescribed by Horace in his De Arte Poetica, and in several of his 
epistles, and we cannot doubt but that his discourse was of eminent use and interest to the Elizabethan audience to whom it was addressed. It is to be noted that, like Puttenham, his acquaintance with the classics was rather literary than exact. He makes Pindar older than Homer, and Ovid than Horace. Still, he earns high praise from that just judge, Professor Saintsbury, who writes in his monumental History of Criticism :

On the whole, to use the hackneyed old phrase once more, we could have better spared a better critic than Webbe, who gives us-in a fashion invaluable to mapmakers of the early exploration of English criticism-the workings of a mind furnished with no original genius for poetry, and not much for literature, not very extensively or accurately erudite, but intensely interested in matters literary, and especially in matters poetical, generously enthusiastic for such good things as were presented to it, not without some mother-wit even in its crazes, and encouraged in those crazes not, as in Harvey's case, by vanity, pedantry, and bad taste, but by its very love of letters. Average dispositions of this kind were, as a rule, diverted either into active life-very much for the good of the nation-or-not at all for its good-into the acrid disputes of hot-gospelling and Puritanism. Webbe, to the best of his modest powers, was a devotee of literature : for which let him have due honour.

Finally, we reproduce the three dedicatory epistles which belong to these treatises. The first is signed by Henry Olney, the printer and publisher of Sir Philip Sidney's Apology in I595, and is addressed to the reader. The anonymous Art of English Poesy was dedicated by Richard Feild, its printer, to Lord Burleigh in somewhat extravagant terms, and Webbe writes his own dedication to Edward Sulyard, to whose sons he was acting as tutor at this time.

The publisher's dedication to 'An Apology for Poetry: written by the right noble, virtuous and learned Sir Philip Sidney, Knight' : London, I 595. 


\section{TO THE READER}

THE stormy Winter, dear Children of the Muses, which hath so long held back the glorious Sunshine of divine Poesy, is here by the sacred pen-breathing words of divine Sir Philip Sidney, not only chased from our fameinviting Clime, but utterly for ever banished eternity: then graciously we greet the perpetual spring of evergrowing invention, and like kind Babes, either enabled by wit or power, help to support me poor Midwife, whose daring adventure hath delivered from Oblivion's womb this ever-to-be-admired wit's miracle. Those great ones who in themselves have interred this blessed innocent, will with Aesculapius condemn me as a detractor from their Deities: those who Prophet-like have but heard presage of his coming, will (if they will do well) not only defend but praise me, as the first public bewrayer of Poesy's Messiah. Those who neither have seen, thereby to inter, nor heard, by which they might be inflamed with desire to see, let them (of duty) plead to be my Champions, sith both their sight and hearing, by mine incurring blame is seasoned. Excellent Poesy (so created by this Apology) be thou my Defendress; and if any wound me, let thy beauty (my soul's Adamant) re-cure me: if any commend mine endeavoured hardiment, to them commend thy most divinest fury as a winged encouragement; so shalt thou have devoted to thee, and to them obliged.

Henry Olney.

The Publisher's Dedication to 'The Art of English Poesy: contrived into three Books: the first of Poets and Poesy, the second of Proportion, the third of Ornament': London, I589.

To the Right Honourable Sir William Cecil, KNight, Lord of Burghley, Lord High TreaSURer of ENgland, R[ICHaRd] F[EILd], Printer, Wisheth HEALTH AND PROSPERITy, WITH THB Commandment and USE of his Continual Service.

TH1s Book (Right Honourable) coming to my hands, with his bare title without any Author's name or any other ordinary address, I doubted how well it might become me to make you a present thereof, seeming by many express passages in the same at large, that it was 
by the Author intended to our Sovereign Lady the Queen, and for her recreation and service chiefly devised, in which case to make any other person her Highness's partner in the honour of his gift it could not stand with my duty, nor be without some prejudice to her Majesty's interest and his merit. Perceiving besides the title to purport so slender a subject as nothing almost could be more discrepant from the gravity of your years and honourable function, whose contemplations are every hour more seriously employed upon the public administration and services: I thought it no condign gratification, nor scarce any good satisfaction for such a person as you. Yet when I considered that bestowing upon your Lordship the first view of this mine impression (a feat of mine own simple faculty) it could not cipher her Majesty's honour or prerogative in the gift, nor yet the Author of his thanks: and seeing the thing itself to be a device of some novelty (which commonly giveth every good thing a special grace), and a novelty so highly tending to the most worthy praises of her Majesty's most excellent name (dearer to you, I dare conceive, than any worldly thing besides) methought I could not devise to have presented your Lordship any gift more agreeable to your appetite, or fitter for my vocation and ability to bestow, your Lordship being learned and a lover of learning, my present a book and myself a printer always ready and desirous to be at your honourable commandment. And thus I humbly take my leave from the Blackfriars, this xxviii, of May, I 589, Your Honour's most humble at commandment,

R. F.

The Author's Dedication to ' $A$ Discourse of English Poetry. Together with the author's Judgment touching the reformation of our English verse, by William Webbe, Graduate'. London, 1586.

To THE Right Worshipful, LEARNED, AND MOST GENTLE Gentleman, our Very Good Master Master Edward Suliard, EsQuire, W[illiam] IV[EBbE] WISHETH HIS HEART'S DESIRE.

MAY it please you, Sir, this once more to bear with my rudeness in presenting unto your view another slender conceit, of my simple capacity: wherein, although I anı not able to bring you anything which is neet to 
detain you from your more serious matters, yet upon my knowledge of your former courtesy and your favourable countenance towards all enterprises of Learning, I dare make bold to crave your accustomed patience, in turning over some of these few leaves, which I shall account a greater recompense, then the writing thereof may deserve.

The firm hope of your wonted gentleness, not any good liking of mine own labour, made me thus presumptuously to crave your Worship's patronage for my poor book. A pretty answer is reported by some to be made by Apelles to King Alexander, who (in disport) taking up one of his pencils to draw a line, and asking the Painter's judgment of his draught, 'It is done', quoth Apelles, 'like a King': meaning indeed it was drawn as he pleased, but was nothing less than good workmanship. Myself in like sort, taking upon me to make a draught of English Poetry, and requesting your Worship's censure of the same, you will perhaps give me this verdict, 'It was done like a Scholar ', meaning, as I could, but indeed more like to a learner than one through grounded in poetical workmanship.

Alexander, in drawing his line, leaned sometime too hard, otherwhile too soft, as never having been apprentice to the Art: I in drawing this poetical discourse, make it some where too straight (leaving out the chief colours and ornaments of Poetry), in another place too wide (stuffing in pieces little pertinent to true Poetry) as one never acquainted with the learned Muses. What then ? As he, being a king, might meddle in what science him listed, though therein he had no skill: so I, being a learner, will try my cunning in some parts of Learning, though never so simple.

Now, as for my saucy pressing upon your expected favour in craving your judgment, I beseech you let me make this excuse: that whereas true Gentility did never withdraw her loving affection from Lady Learning, so I am persuaded, that your Worship cannot choose but continue your wonted favourable benignity towards all the endeavourers to learning, of which corporation I do indeed profess myself one silly member.

For sith the writers of all ages have sought as an undoubted Bulwark and stedfast safeguard the patronage of Nobility (a shielde as sure as can be to learning), wherein to shroud and safely place their several inventions; why should not I seek some harbour for my poor travail to rest and stay upon, being of itsclf unable 
to shift the carping cavils and biting scorns of lewd controllers?

And in truth, where might I rather choose a sure defence and ready refuge for the same, then where I see perfect Gentility and nobleness of mind to be fast linked with excellency of learning and affable courtesy ? Moreover, add this to the end of mine excuse : that I send it into your sight, not as any witty piece of work that may delight you, but being a slight somewhat compiled for recreation, in the intermissions of my daily business (even this Summer Evenings), as a token of that earnest and unquenchable desire I have to show myself dutiful and well-willing towards you. Whereunto I am continually inflamed more and more, when I consider either your favourable friendship used towards myself, or your gentle countenance showed to my simple travails. The one I have tried in that homely translation I presented unto you : the other I find true in your courteous putting to my trust and doing me so great honesty and credit, with the charge of these toward young Gentlemen your sons.

To which pregnant imps of right excellent hope I would I were able or you might have occasion to make trial of my loving mind: who should well perceive myself to remain unto them a faithful and trusty Achates, even so far as my wealth, my woe, my power or peril, my pen or wit, my health or life may serve to search mine ability.

Huge heaps of words I might pile together to trouble you withal: either of myself or of my doings (as some do), or of your Worship's commendable virtues (as the most do). But I purposely choose rather to let pass the spreading of that worthy fame which you have ever deserved, than to run in suspicion of fawning flattery which I ever abhorred.

Therefore once again craving your gentle pardon, and patience in your overlooking this rude Epistle: and wishing more happiness than my pen can express to you and your whole retinue, I rest,

Your Worship's faithful Servant,

W. W. 


\section{SIR PHILIP SIDNEY}

\section{AN}

\section{APOLOGY FOR POETRY}

WHEN the right virtuous Edward Wotton ${ }^{1}$ and I were at the Emperor's Court together, we gave ourselves to learn horsemanship of John Pietro Pugliano: one that with great commendation had the place of an Esquire in his stable. And he, according to the fertileness of the Italian wit, did

1 Edward Wotton (I 548-1626) was created Baron Wotton in 1603 . The Emperor was Rudolf II, and the date of the embassy 1577 .

As a point of style, it may be urged that Sidney's exordium is too long. The analogy between Pugliano's defence of horsemanship and Sidney's defence of poetry - each craftsman praising his own-is artistic in conception, but English prose had not yet sufficiently developed the laws of proportion and restraint in the marshalling of ideas. But note at the same time the elevation of the style. The light touch and modulation of pitch which were to characterize the British essayists of succeeding centuries, till the art reached its height in the inimitable Lamb, were already immanent in such phrases as 'if I had not been a piece of a logician . . . he would have persuaded me to have wished myself a horse.' Sidney's essay, alone in this volume, is good literature as well as interesting criticism. Puttenham and Webbe are pedestrian writers. E.L. 
not only afford us the demonstration of his practice, but sought to enrich our minds with the contemplations therein which he thought most precious. But with none I remember mine ears were at any time more laden than when (either angered with slow payment or moved with our learner-like admiration) he exercised his speech in the praise of his faculty. He said Soldiers were the noblest estate of mankind, and horsemen the noblest of Soldiers. He said, they were the Masters of war, and ornaments of peace: speedy goers, and strong abiders, triumphers both in Camps and Courts. Nay, to so unbelieved a point he proceeded, as that no earthly thing bred such wonder to a Prince as to be a good horseman. Skill of government was but a Pedanteria in comparison : then would he add certain praises, by telling what a peerless beast a horse was. The only serviceable Courtier without flattery, the beast of most beauty, faithfulness, courage, and such more, that, if I had not been a piece of a Logician before I came to him, I think he would have persuaded me to have wished myself a horse. But thus much at least with his no few words he drove into me, that selflove is better than any gilding to make that seem gorgeous, wherein ourselves are parties.

Wherein, if Pugliano's strong affection and weak arguments will not satisfy you, I will give you a nearer example of myself, who (I know not by what mischance) in these my not old years and idlest times having slipt into the title of a Poet, am provoked to say something unto you in the defence of that my unelected vocation ${ }^{2}$, which

2 In reference to Stephen Gosson (author of The School 


\section{An Apology for Poetry}

if I handle with more good will than good reasons, bear with me, since the scholar is to be pardoned that followeth the steps of his Master. And yet I must say that, as I have just cause to make a pitiful defence of poor Poetry, which from almost the highest estimation of learning is fallen to be the laughing stock of children, so have I need to bring some more available proofs : since the former is by no man barred of his deserved credit, the silly latter hath had even the names of Philosophers used to the defacing of it, with great danger of civil war among the Muses.

And first, truly to all them that professing learning inveigh against Poetry may justly be objected, that they go very near to ungratefulness to seek to deface that which in the noblest nations and languages that are known hath been the first light-giver to ignorance, and first Nurse, whose milk by little and little enabled them to feed afterwards of tougher knowledges : and will they now play the Hedgehog, that being received into the den, drove out his host ?, or rather the Vipers, that with their birth kill their Parents ${ }^{3}$ ? Let learned Greece in any of her manifold Sciences be able to show me one book, before Musæus, Homer, and Hesiod, all three nothing else but Poets. Nay, let any history be brought, that can say any writers were there before them, if they

of Abuse, 1579, to which this treatise is in the nature of a reply), who had without authority used Sidney's name in dedicatory epistles.

3 The use of illustrations from natural history is a Euphuistic conceit natural to the times. Lyly's Euphues was published in 1579 . 
were not men of the same skill as Orpheus, Linus, and some other are named; who, having been the first of that Country that made pens deliverers of their knowledge to their posterity, may justly challenge to be called their Fathers in learning. For not only in time they had this priority (although in itself antiquity be venerable) but went before them, as causes to draw with their charming sweetness the wild untamed wits to an admiration of knowledge. So Amphion was said to move stones with his Poetry to build Thebes, and Orpheus to be listened to by beasts, indeed, stony and beastly people. So among the Romans were Livius Andronicus and Ennius ${ }^{4}$. So, in the Italian language, the first that made it aspire to be a Treasure-house of Science, were the Poets Dante, Boccacio, and Petrarch. So in our English were Gower and Chaucer.

After whom, encouraged and delighted with their excellent fore-going, others have followed, to beautify our mother-tongue, as well in the same kind as in other Arts. This did so notably show itself that the Philosophers of Greece durst not a long time appear to the world but under the masks of Poets. So Thales, Empedocles, and Parmenides sang their Natural Philosophy in verses : so did Pythagoras and Phocilides their moral counsels : so did Tyrtæus in war matters, and Solon in matters of policy. Or, rather, they being Poets, did

4 Livius Andronicus was a Greek slave at Rome (c. 275 B.c.). His Latin versions of Greek authors were used for many years as text-books in schools. Ennius in the next century was an early epic writer, and Sidney might have mentioned Naevius (269-204 B.C.), who was a Latin by birth, and a much better writer than $\Lambda$ ndronicus. 
exercise their delightful vein in those points of highest knowledge which before them lay hid to the world. For that wise Solon was directly a Poet, it is manifest, having written in verse the notable fable of the Atlantic Island, which was continued by Plato.

And truly, even Plato, whosoever well considereth shall find that in the body of his work, though the inside and strength were Philosophy, the skin as it were and beauty depended most of Poetry. For all standeth upon Dialogues, wherein he feigneth many honest burgesses of Athens to speak of such matters that if they had been set on the rack they would never have confessed them. Besides, his poetical describing the circumstances of their meetings, as the well ordering of a banquet, the delicacy of a walk, with interlacing mere tales, as Gyges' Ring, and others, which who knoweth not to be flowers of Poetry did never walk into Apollo's Garden.

And even Historiographers (although their lips sound of things done, and verity be written in their foreheads) have been glad to borrow both fashion and perchance weight of Poets. So Herodotus entituled his History by the name of the nine Muses; and both he and all the rest that followed him either stole or usurped of Poetry their passionate describing of passions, the many particularities of battles, which no man could affirm; or if that be denied me, long Orations put in the mouths of great Kings and Captains, which it is certain they never pronounced. So that truly, neither Philosopher nor Historiographer could at the first have entered into the gates of 
popular judgments, if they had not taken a great passport of Poetry, which in all Nations at this day where learning flourisheth not is plain to be seen : in all which they have some feeling of Poetry.

In Turkey, besides their law-giving Divines, they have no other writers but Poets. In our neighbour Country Ireland, where truly learning goeth very bare, yet are their Poets held in a devout reverence. Even among the most barbarous and simple Indians, where no writing is, yet have they their Poets who make and sing songs which they call Areytos, both of their Ancestors' deeds and praises of their Gods. A sufficient probability, that, if ever learning come among them, it must be by having their hard dull wits softened and sharpened with the sweet delights of Poetry. For until they find a pleasure in the exercises of the mind, great promises of much knowledge will little persuade them that know not the fruits of knowledge. In Wales, the true remnant of the ancient Britons, as there are good authorities to show the long time they had Poets, which they called Bards, so through all the conquests of Romans, Saxons, Danes, and Normans, some of whom did seek to ruin all memory of learning from among them, yet do their Poets even to this day last; so that it is not more notable in soon beginning than in long continuing ${ }^{5}$.

- Sidney covers this familiar ground more rapidly than other writers in his age. The argument is that, because metrical composition preceded prose in date, therefore poetry should be held in higher honour. The reasoning is both unscientific and fallacious. Neither Sidney nor 


\section{An Apology for Poetry}

But since the Authors of most of our Sciences were the Romans, and before them the Greeks, let us a little stand upon their authorities, but even so far as to see what names they have given unto this now scorned skill.

Among the Romans a Poet was called Vates, which is as much as a Diviner, Fore-seer, or Prophet, as by its conjoined words, Vaticinium and Vaticinari, is manifest: so heavenly a title did that excellent people bestow upon this heartravishing knowledge. And so far were they carried into the admiration thereof, that they thought in the chanceable hitting upon any such verses great fore-tokens of their following fortunes were placed. Whereupon grew the word of Sortes Virgiliance, when by sudden opening Virgil's book they lighted upon any verse of his making, whereof the histories of the Emperors' lives are full : as of Albinus the Governor of our Island, who in his childhood met with this verse

Arma amens capio nec sat rationis in armis,

and in his age performed it; which, although it were a very vain and godless superstition, as also it was to think that spirits were commanded by

his contemporaries tell us why poetry should not be the more despised, if, on their own showing, the fathers of learning, philosophers, historiographers and so forth, adopted prose instead of verse at the earliest available opportunity. The fact is that the argument from the primitive mnemonic uses of rude metrical forms for oracular and other purposes has no bearing whatsoever on the value of poetry as a branch of literary composition. Sidney himself is doubtful of the validity of the plea from antiquity, and he seems more pleased than Puttenham (see infra) to leave this part of his ' apology' behind hin. 
such verses, whereupon this word 'charms', derived of Carmina, cometh, so yet serveth it to show the great reverence those wits were held in. And altogether not without ground, since both the Oracles of Delphos and Sibylla's prophecies were wholly delivered in verses. For that same exquisite observing of number and measure in words, and that high-flying liberty of conceit proper to the Poet, did seem to have some divine force in it.

And may not I presume a little further to show the reasonableness of this word $V$ ates, and say that the holy David's Psalms are a divine Poem ? If I do, I shall not do it without the testimony of great learned men, both ancient and modern : but even the name Psalms will speak for me, which, being interpreted, is nothing but songs. Then that it is fully written in metre, as all learned Hebricians agree, although the rules be not yet fully found. Lastly and principally, his handling his prophecy, which is merely poetical. For what else is the awaking his musical instruments?, the often and free changing of persons?, his notable Prosopopeias ${ }^{6}$, when he maketh you, as it were, see God coming in His Majesty?, his telling of the Beasts' joyfulness, and hills leaping, but a heavenly poesy?; wherein almost he showeth himself a passionate lover of that unspeakable and everlasting beauty to be seen by the eyes of the mind, only cleared by faith. But truly now having named him, I fear me I seem to profane that holy name, applying it to Poetry, which is among us

6 Personifications. 
thrown down to so ridiculous an estimation. But they that with quiet judgments will look a little deeper into it shall find the end and working of it such, as being rightly applied, deserveth not to be scourged out of the Church of God.

But now let us see how the Greeks named it, and how they deemed of it. The Greeks called him a Poet, which name hath, as the most excellent, gone through other Languages. It cometh of this word Poiein, which is, to make : wherein I know not whether by luck or wisdom we Englishmen have met with the Greeks in calling him a maker : which name, how high and incomparable a title it is, I had rather were known by marking the scope of other Sciences than by my partial allegation.

There is no Art delivered to mankind that hath not the works of Nature for its principal object, without which they could not consist, and on which they so depend that they become Actors and Players, as it were, of what Nature will have set forth. So doth the Astronomer look upon the stars, and by that he seeth setteth down what order Nature hath taken therein. So do the Geometrician and Arithmetician in their divers sorts of quantities. So doth the Musician in times tell you which by nature agree, which not. The Natural Philosopher thereon hath his name, and the Moral Philosopher standeth upon the natural virtues, vices, and passions of man ; and follow Nature (saith he) therein, and thou shalt not err. The Lawyer saith what men have determined, the Historian what men have done. The Grammarian speaketh only of the rules of speech, 
and the Rhetorician and Logician, considering what in Nature will soonest prove and persuade, thereon give artificial rules, which still are compassed within the circle of a question, according to the proposed matter. The Physician weigheth the nature of a man's body, and the nature of things helpful or hurtful unto it. And the Metaphysic, though it be in the second and abstract notions, and therefore be counted supernatural, yet doth he indeed build upon the depth of Nature. Only the Poet, disdaining to be tied to any such subjection, lifted up with the vigour of his own invention, doth grow in effect another nature, in making things either better than Nature bringeth forth, or quite a new form such as never were in Nature, as the Heroes, Demigods, Cyclops, Chimeras, Furies, and such like. So that he goeth hand in hand with Nature, not inclosed within the narrow warrant of her gifts, but freely ranging only within the Zodiac of his own wit ${ }^{7}$.

Nature never set forth the earth in so rich tapestry as divers Poets have done, neither with pleasant rivers, fruitful trees, sweet-smelling flowers, nor whatsoever else may make the too much loved earth more lovely. Her world is brazen :

7 The argument in the foregoing paragraphs is far in advance of the conventional moralizing on the words vates and $\pi \circ \in \hat{\imath} \nu$. The splendid testimony to the literary value of psalms is unique in its age, and the maxim that ' there is no art that hath not the works of nature for its principal object ' is a sound and notable canon of criticism. Finally, the remark that "the poet doth grow in effect another nature' goes to the root of the distinction between the truths ascertained by the observation and the higher truths adumbrated by the interpretation of nature. 


\section{An Apology for Poetry}

the Poets only deliver a golden. But let those things alone and go to man, for whom as the other things are, so it seemeth in him her uttermost cunning is employed, and know whether she have brought forth so true a lover as Theagines, so constant a friend as Pylades, so valiant a man as Orlando, so right a Prince as Xenophon's Cyrus, so excellent a man every way as Virgil's Aeneas. Neither let this be jestingly conceived, because the works of the one be essential ; the other, in imitation or fiction-for any understanding knoweth the skill of the Artificer-standeth in that Idea or fore-conceit of the work, and not in the work itself. And that the Poet hath that Idea is manifest by delivering them forth in such excellence as he hath imagined them. Which delivering forth also is not wholly imaginative, as we are wont to say by them that build Castles in the air ; but so far substantially it worketh not only to make a Cyrus, which had been but a particular excellency as Nature might have done, but to bestow a Cyrus upon the world, to make many Cyruses, if they will learn aright why and how that Maker made him.

Neither let it be deemed too saucy a comparison to balance the highest point of man's wit with the efficacy of Nature : but rather give right honour to the heavenly Maker of that maker, who, having made man to his own likeness, set him beyond and over all the works of that second nature, which in nothing he showeth so much as in Poetry: when with the force of a divine breath he bringeth things forth far surpassing her doings, with no small argument to the incredulous of that first accursed 
fall of Adam : since our erected wit maketh us know what perfection is, and yet our infected will keepeth us from reaching unto it ${ }^{8}$. But these arguments will by few be understood and by fewer granted. Thus much (I hope) will be given me, that the Greeks with some probability of reason gave it the name above all names of learning. Now let us go to a more ordinary opening of it, that the truth may be more palpable: and so I hope, though we get not so unmatched a praise as the Etymology of its names will grant, yet its very description, which no man will deny, shall not justly be barred from a principal commendation.

Poesy therefore is an art of imitation, for so Aristotle termeth it in his word Mimesis, that is to say, a representing, counterfeiting, or figuring forth: to speak metaphorically, a speaking picture : with this end, to teach and delight. Of this have been three several kinds. The chief both in antiquity and excellency were they that did imitate the inconceivable excellencies of God. Such were David in his Psalms; Solomon in his Song of Songs, in his Ecclesiastes, and Proverbs ; Moses and Deborah in their Hymns, and the writer of Job ; which, beside other, the learned Emanuel Tremilius and Franciscus Junius do entitle the poetical part of the Scripture. Against these none will speak that hath the Holy Ghost in due holy reverence.

In this kind, though in a full wrong divinity, were

8 'Erected wit . . . infected will'; a Euphuistic turn of phrase. 
Orpheus, Amphion, Homer in his hymns, and many other, both Greeks and Romans : and this Poesy must be used by whosoever will follow St James' counsel in singing Psalms when they are merry: and $I$ know is used with the fruit of comfort by some, when in sorrowful pangs of their deathbringing sins they find the consolation of the neverleaving goodness ${ }^{9}$.

The second kind is of them that deal with matters Philosophical ; either moral, as Tyrtæus, Phocilides and Cato, or natural, as Lucretius and Virgil's Georgics : or Astronomical, as Manilius, and Pontanus: or historical, as Lucan: which who mislike, the fault is in their judgments quite out of taste, and not in the sweet food of sweetly uttered knowledge. But because this second sort is wrapped within the fold of the proposed subject, and takes not the course of his own invention, whether they properly be Poets, or no, let Grammarians dispute : and go to the third, indeed right Poets, of whom chiefly this question ariseth ; betwixt whom and these second is such a kind of difference as betwixt the meaner sort of Painters (who counterfeit only such faces as are set before them) and the more excellent, who having no law but wit, bestow that in colours upon you which is fittest for the eye to see: as the constant though lamenting look of Lucretia, when she punished in herself another's fault.

Wherein he painteth not Lucretia, whom he

9 Sir Philip Sidney began, and the Countess of Pembroke completed, a metrical translation of the Psalms. See R. E. Prothero, The Psalms in Human Life (Murray), ch. vi. 
never saw, but painteth the outward beauty of such a virtue. For these third be they which most properly do imitate to teach and delight, and to imitate, borrow nothing of what is, hath been, or shall be: but range only reined with learned discretion into the divine consideration of what may be, and should be. These be they that, as the first and most noble sort may justly be termed Vates, so these are waited on in the excellentest languages and best understandings with the fore-described name of Poets. For these indeed do merely make to imitate : and imitate both to delight and teach : and delight to move men to take that goodness in hand which without delight they would fly as from a stranger. And teach, to make them know that goodness whereunto they are moved, which, being the noblest scope to which ever any learning was directed, yet want there not idle tongues to bark at them. These be subdivided into sundry more special denominations. The most notable are the Heroic, Lyric, Tragic, Comic, Satiric, Iambic, Elegiac, Pastoral, and certain others; some of these being termed according to the matter they deal with, some by the sorts of verses they liked best to write in, for indeed the greatest part of Poets have apparelled their poetical inventions in that numbrous kind of writing which is called verse : indeed but apparelled, verse being but an ornament and no cause to Poetry ${ }^{10}$ : since there have been many

10 This touches the fringe of what is now an old debate, whether poetry is a mode of feeling or a form of expression, or both combined. 


\section{An Apology for Poetry}

most excellent Poets that never versified, and now swarm many versifiers that need never answer to the name of Poets. For Xenophon, who did imitate so excellently as to give us effigiem justi imperii, the portraiture of a just Empire, under the name of Cyrus, (as Cicero saith of him) made therein an absolute heroical Poem.

So did Heliodorus in his sugared invention of that picture of love in Theagines and Cariclea, and yet both these wrote in Prose : which I speak to show that lit is not rhyming and versing that maketh a Poet, no more than a long gown maketh an Advocate, who, though he pleaded in armour should be an Advocate and no Soldier. But it is that feigning notable images of virtues, vices, or what else, with that delightful teaching which must be the right describing note to know a Poet by: although indeed the Senate of Poets hath chosen verse as their fittest raiment, meaning, as in matter they passed all in all, so in manner to go beyond them: not speaking (table-talk fashion or like men in a dream) words as they chanceably fall from the mouth, but poising each syllable of each word by just proportion according to the dignity of the subject.

Now, therefore, it shall not be amiss first to weigh this latter sort of Poetry by its works, and then by its parts; and if in neither of these Anatomies it be condemnable, I hope we shall obtain a more favourable sentence. This purifying of wit, this enriching of memory, enabling of judgment, and enlarging of conceit, which commonly we call learning, under what name soever it come forth, or to what immediate end soever it 
be directed, the final end is to lead and draw us to as high a perfection as our degenerate souls made worse by their clayey lodgings can be capable of. This, according to the inclination of the man, bred many-formed impressions ; for some that thought this felicity principally to be gotten by knowledge, and no knowledge to be so high and heavenly as acquaintance with the stars, gave themselves to Astronomy; others, persuading themselves to be Demi-gods if they knew the causes of things, became natural and supernatural Philosophers; some an admirable delight drew to Music; and some the certainty of demonstration to the Mathematics : but all, one and other, having this scope to know, and by knowledge to lift up the mind from the dungeon of the body to the enjoying its own divine essence.

But when by the balance of experience it was found that the Astronomer looking to the stars might fall into a ditch, that the inquiring Philosopher might be blind in himself, and the Mathematician might draw forth a straight line with a crooked heart, then lo! did proof, the overruler of opinions, make manifest that all these are but serving Sciences which, as they have each a private end in themselves, so yet are they all directed to the highest end of the mistress Knowledge, by the Greeks called Architechtonike, which stands (as I think) in the knowledge of a man's self, in the ethic and politic consideration, with the end of well doing and not of well-knowing only; even as the saddler's next end is to make a good saddle, but his farther end to serve a nobler faculty, which is horsemanship, so the horseman's 
to soldiery, and the Soldier not only to have the skill but to perform the practice of a Soldier. So that the ending end of all earthly learning being virtuous action, those skills that most serve to bring forth that have a most just title to be Princes over all the rest: wherein if we can show the Poet's nobleness, by setting him before his other Competitors, among whom as principal challengers step forth the Moral Philosophers, whom, methinketh, I see coming towards me with a sullen gravity, as though they could not abide vice by daylight, rudely clothed for to witness outwardly their contempt of outward things, with books in their hands against glory, whereto they set their names, sophistically speaking against subtlety, and angry with any man in whom they see the foul fault of anger: these men, casting largess as they go of Definitions, Divisions and Distinctions, with a scornful interrogative do soberly ask, whether it be possible to find any path so ready to lead a man to virtue as that which teacheth what virtue is; and teacheth it not only by delivering forth its very being, its causes and effects ; but also by making known its enemy vice, which must be destroyed, and its cumbersome servant Passion, which must be mastered, by showing the generalities that containeth it, and the specialities that are derived from it. Lastly, by plain setting down how it extendeth itself out of the limits of a man's own little world to the government of families and maintaining of public societies.

The Historian scarcely giveth leisure to the Moralist to say so much, but that he-laden with E.L. 
old mouse-eaten records, authorizing himself (for the most part) upon other histories, whose greatest authorities are built upon the notable foundation of hear-say, having much ado to accord differing writers, and to pick truth out of partiality, better acquainted with a thousand years ago than with the present age, and yet better knowing how this world goeth than how his own wit runneth, curious for antiquities, and inquisitive of novelties, a wonder to young folks and a tyrant in table-talk-denieth in a great chafe that any man for teaching of virtue, and virtuous actions, is comparable to him. I am Lux vitae, Temporum Magistra, Vita memoriae, Nuncia vetustatis, etc.

The Philosopher (saith he) teacheth a disputative virtue, but I do an active: his virtue is excellent in the dangerless Academy of Plato, but mine showeth forth her honourable face in the battles of Marathon, Pharsalia, Poitiers, and Agincourt. He teacheth virtue by certain abstract considerations, but I only bid you follow the footing of them that have gone before you. Old-aged experience goeth beyond the fine-witted Philosopher, but I give the experience of many ages. Lastly, if he make the Song-book, I put the learner's hand to the Lute: and if he be the guide, I am the light.

Then would he allege you innumerable examples, conferring story by story how much the wisest Senators and Princes have been directed by the credit of history, as Brutus, Alphonsus of Aragon, and who not, if need be ? At length, the long line of their disputation maketh a point in 
this, that the one giveth the precept and the other the example ${ }^{11}$.

Now, whom shall we find (since the question standeth for the highest form in the School of learning) to be Moderator ? Truly, as meseemeth, the Poet; and, if not a Moderator, even the man that ought to carry the title from them both, and much more from all other serving Sciences. Therefore compare we the Poet with the Historian, and with the Moral Philosopher, and, if he go beyond them both, no other human skill can match him. For as for the Divine, with all reverence it is ever to be excepted, not only for having its scope as far beyond any of these as eternity exceedeth a moment, but even for passing each of these in themselves.

And for the Lawyer, though Jus be the Daughter of Justice, and Justice the chief of Virtues, yet because he seeketh to make men good rather Formidine pance than Virtutis amore, or, to say righter, doth not endeavour to make men good but that their evil hurt not others: having no care, so he be a good Citizen, how bad a man he be. Therefore, as our wickedness maketh him necessary, and necessity maketh him honourable, so is he not in the deepest truth to stand in rank with these; who all endeavour to take

11 The argument is sound, and it is eloquently stated : moral philosophy teaches by precept, history by example, the common aim of both being conduct; the poet therefore shall be compared with each, and, "if he go beyond them both, no other human skill can match him'. The knowledge-value of poetry, as a medium of truth, must always rest on this proof. 
naughtiness away, and plant goodness even in the secretest cabinet of our souls. And these four are all that any way deal in that consideration of men's manners, which being the supreme knowledge they that best breed it deserve the best commendation.

The Philosopher therefore and the Historian are they which would win the goal: the one by precept, the other by example. But both not having both do both halt. For the Philosopher, setting down with thorny argument the bare rule, is so hard of utterance, and so misty to be conceived, that one that hath no other guide but him shall wade in him till he be old before he shall find sufficient cause to be honest: for his knowledge standeth so upon the abstract and general, that happy is that man who may understand him, and more happy that can apply what he doth understand.

On the other side, the Historian, wanting the precept, is so tied, not to what should be but to what is, to the particular truth of things, and not to the general reason of things, that his example draweth no necessary consequence, and therefore a less fruitful doctrine.

Now doth the peerless Poet perform both. For whatsoever the Philosopher saith should be done, he giveth a perfect picture of it in some one by whom he presupposeth it was done. So that he coupleth the general notion with the particular example. A perfect picture, I say, for he yieldeth to the powers of the mind an image of that whereof the Philosopher bestoweth but a wordish description: which doth neither strike, pierce, nor 
possess the sight of the soul so much as that other doth.

For as in outward things, to a man that had never seen an Elephant or a Rhinoceros, who should tell him most exquisitely all their shapes, colour, bigness, and particular marks : or of a gorgeous Palace, the Architecture, with declaring the full beauties, might well make the hearer able to repeat, as it were by rote, all he had heard, yet should never satisfy his inward conceits, with being witness to itself of a true lively knowledge : but the same man, as soon as he might see those beasts well painted, or the house well in model, should straightways grow without need of any description to a judicial comprehending of them, so no doubt the Philosopher with his learned definition, be it of virtue, vices, matters of public policy, or private government, replenisheth the memory with many infallible grounds of wisdom : which notwithstanding, lie dark before the imaginative and judging power, if they be not illuminated or figured forth by the speaking picture of Poesy. Tully ${ }^{12}$ taketh much pains, and many times not without poetical helps, to make us know the force love of our Country hath in us. Let us but hear old Anchises speaking in the midst of Troy's flames, or see Ulysses in the fullness of all Calypso's delights bewail his absence from barren and beggarly Ithaca. Anger, the Stoics say, was a short madness ; let but Sophocles bring you Ajax on a stage, killing and whipping Sheep and Oxen, thinking them the Army of Greeks, with their 
Chieftains Agamemnon and Menelaus, and tell me if you have not a more familiar insight into anger than finding in the Schoolmen its gemus and difference. See whether wisdom and temperance in Ulysses and Diomedes, valour in Achilles, friendship in Nisus, and Euryalus, even to an ignorant man carry not an apparent shining : and, contrarily, the remorse of conscience in Oedipus, the soon-repenting pride of Agamemnon, the self-devouring cruelty in his father Atreus, the violence of ambition in the two Theban brothers, the sour-sweetness of revenge in Medea, and, to fall lower, the Terentian Gnato, and our Chaucer's Pandar, so expressed that we now use their names to signify their trades ${ }^{13}$. And finally, all virtues, vices, and passions, so in their own natural seats laid to the view that we seem not to hear of them but clearly to see through them. But even in the most excellent determination of goodness, what Philosopher's counsel can so readily direct a Prince as the feigned Cyrus in Xenophon ?, or a virtuous man in all fortunes, as Aeneas in Virgil ?, or a whole Commonwealth as the way of Sir Thomas More's Utopia? I say the way, because where Sir Thomas More erred, it was the fault of the man and not of the Poet, for that way of patterning a Commonwealth was

13 Shakespeare's gallery of examples was to be added in the next ten years to this list of personified precepts. Othello as the type of jealousy; Hamlet of indecision; Lear as the victim of filial ingratitude ; Juliet as a synonym for Southern love ; Shylock for usury, and so forth, illustrate even more effectively than Sidney's allusions the power of great poetry to represent the qualities which moral philosophy defines. 
most absolute, though he perchance hath not so absolutely performed it. For the question is, whether the feigned image of Poesy or the regular instruction of Philosophy hath the more force in teaching: wherein if the Philosophers have more rightly showed themselves Philosophers than the Poets have attained to the high top of their profession, as in truth

Mediocribus esse poetis,

Non Di, non homines, non concessere Columnæ 14

it is, I say again, not the fault of the Art but that by few men that Art can be accomplished.

Certainly, even our Saviour Christ could as well have given the moral commonplaces of uncharitableness and humbleness as the divine narration of Dives and Lazarus : or of disobedience and mercy as that heavenly discourse of the lost Child and the gracious Father; but that his thorough-searching wisdom knew the estate of Dives burning in hell and of Lazarus being in Abraham's bosom would more constantly (as it were) inhabit both the memory and judgment. Truly, for myself, meseems I see before my eyes the lost Child's disdainful prodigality turned to envy a Swine's dinner: which, by the learned Divines, are thought not historical acts but instructing Parables. For conclusion, I say the Philosopher teacheth, but he teacheth obscurely, so that the learned only can understand him.

14 Horace, Ars Poetica, 372-3. 'Nor gods, nor men, nor the booksellers tolerate minor poets.' The 'column' was the pillar in front of the shop. 
That is to say, he teacheth them that are already taught, but the Poet is the food for the tenderest stomachs, the Poet is indeed the right Popular Philosopher, whereof Aesop's tales give good proof : whose pretty Allegories, stealing under the formal tales of Beasts, make many, more beastly than Beasts, begin to hear the sound of virtue from these dumb speakers.

But now may it be alleged that if this imagining of matters be so fit for the imagination, then must the Historian needs surpass, who bringeth you images of true matters such as indeed were done, and not such as fantastically or falsely may be suggested to have been done. Truly Aristotle himself in his discourse of Poesy plainly determineth this question, saying that Poetry is Philosophoteron and Spoudaioteron, that is to say, it is more philosophical and more studiously serious than history. His reason is because Poesy dealeth with Katholou, that is to say, with the universal consideration; and the history with Kathekaston, the particular. Now, saith he, the universal weighs what is fit to be said or done, either in likelihood or necessity (which the Poesy considereth in its imposed names), and the particular only marks whether Alcibiades did, or suffered, this or that. Thus far Aristotle: which reason of his (as all his) is most full of reason. For indeed, if the question were whether it were better to have a particular act truly or falsely set down, there is no doubt which is to be chosen, no more than whether you had rather have Vespasian's picture right as he was, or at the Painter's pleasure nothing resembling. But if the question be for your own 
use and learning, whether it be better to have it set down as it should be or as it was : then certainly is more doctrinable the feigned Cyrus of Xenophon than the true Cyrus in Justine: and the feigned Aeneas in Virgil than the right Aeneas in Dares Phrigius.

As to a Lady that desired to fashion her countenance to the best grace a Painter should more benefit her to portrait a most sweet face, writing Canidia upon it, than to paint Canidia as she was, who, Horace sweareth, was foul and illfavoured.

If the Poet do his part aright, he will show you in Tantalus, Atreus, and such like, nothing that is not to be shunned. In Cyrus, Aeneas, Ulysses, each thing to be followed; where the Historian, bound to tell things as things were, cannot be liberal (without he will be poetical) of a perfect pattern : but, as in Alexander or Scipio himself, show doings, some to be liked, some to be misliked. And then how will you discern what to follow but by your own discretion, which you had without reading Quintus Curtius?

And whereas a man may say: though in universal consideration of doctrine the Poet prevaileth, yet that the history, in its saying such a thing was done, doth warrant a man more in that he shall follow; the answer is manifest, that if he stand upon that was (as if he should argue, because it rained yesterday, therefore it should rain to-day) then indeed it hath some advantage to a gross conceit. But if he know an example only informs a conjectured likelihood, and so go by reason, the Poet doth so far exceed him, that 
he is to frame his example to that which is most reasonable: be it in warlike, politic or private matters ; where the Historian in his bare 'was' hath many times that which we call fortune to over-rule the best wisdom. Many times he must tell events, whereof he can yield no cause : or if he do, it must be poetical; for that a feigned example hath as much force to teach as a true example : (for as for to move, it is clear, since the feigned may be tuned to the highest key of passion) let us take one example, wherein a Poet and a Historian do concur.

Herodotus and Justine do both testify that Zopirus, King Darius' faithful servant, seeing his Master long resisted by the rebellious Babylonians, feigned himself in extreme disgrace of his King, for verifying of which, he caused his own nose and ears to be cut off : and so flying to the Babylonians, was received, and for his known valour so far credited that he did find means to deliver them over to Darius. Much like matter doth Livy record of Tarquinius and his son. Xenophon excellently feigneth such another stratagem, performed by Abradates in Cyrus' behalf. Now would I fain know, if occasion be presented unto you to serve your Prince by such an honest dissimulation, why you do not as well learn it of Xenophon's fiction as of the other's verity : and truly so much the better, as you shall save your nose by the bargain: for Abradates did not counterfeit so far. So then the best of the Historian is subject to the Poet; for whatsoever action, or faction, whatsoever counsel, policy, or war-stratagem the Historian is bound to recite, 
that may the Poet (if he list) with his imitation make his own; beautifying it both for further teaching, and more delighting, as it pleaseth him : having all, from Dante's heaven to his hell, under the authority of his pen. Which if I be asked what Poets have done so, as I might well name some, yet say I, and say again, I speak of the Art and not of the Artificer.

Now, to that which commonly is attributed to the praise of histories, in respect of the notable learning is gotten by marking the success, as though therein a man should see virtue exalted, and vice punished. Truly that commendation is peculiar to Poetry, and far off from History. For indeed Poetry ever setteth virtue so out in her best colours, making Fortune her well-waiting handmaid, that one must needs be enamoured of her. Well may you see Ulysses in a storm and in other hard plights ; but they are but exercises of patience and magnanimity, to make them shine the more in the near-following prosperity. And of the contrary part, if evil men come to the stage, they ever go out (as the Tragedy-Writer answered to one that misliked the show of such persons) so manacled, as they little animate folks to follow them. But the Historian, being captived to the truth of a foolish world, is many times a terror from well doing, and an encouragement to unbridled wickedness.

For see we not valiant Miltiades rot in his fetters? The just Phocion and the accomplished Socrates put to death like Traitors? The cruel Severus live prosperously? The excellent Severus miserably murdered? Sylla and Marius dying in 
their beds? Pompey and Cicero slain then, when they would have thought exile a happiness?

See we not virtuous Cato driven to kill himself ? and rebel Cæsar so advanced that his name yet after $\mathrm{I}, 600$ years lasteth in the highest honour ? And mark but even Cæsar's own words of the forenamed Sylla, (who in that only did honestly, to put down his dishonest tyranny), Literas nescivit, as if want of learning caused him to do well. He meant it not by Poetry which, not content with earthly plagues, deviseth new punishments in hell for Tyrants: nor yet by Philosophy which teacheth Occidendos esse, but no doubt by skill in History : for that indeed can afford your Cypselus, Periander, Phalaris, Dionysius, and I know not how many more of the same kennel, that speed well enough in their abominable injustice or usurpation. I conclude, therefore, that he excelleth History not only in furnishing the mind with knowledge, but in setting it forward to that which deserveth to be called and accounted good: which setting forward, and moving to well doing, indeed setteth the laurel crown upon the Poet as victorious, not only of the Historian but over the Philosopher: howsoever in teaching it may be questionable.

For suppose it be granted (that which I suppose with great reason may be denied) that the Philosopher in respect of his methodical proceeding doth teach more perfectly than the Poet: yet do I think, that no man is so much Philophilosophos ${ }^{15}$ as to compare the Philosopher in moving with the Poet.

15 A partisan of philosophers. 
And that moving is of a higher degree than teaching, it may by this appear: that it is well nigh the cause and the effect of teaching. For who will be taught, if he be not moved with desire to be taught?; and what so much good doth that teaching bring forth (I speak still of moral doctrine) as that it moveth one to do that which it doth teach? For, as Aristotle saith, it is not Gnosis, but Praxis must be the fruit. And how Praxis cannot be without being moved to practice it is no hard matter to consider.

The Philosopher showeth you the way, he informeth you of the particularities as well of the tediousness of the way as of the pleasant lodging you shall have when your journey is ended, as of the many by-turnings that may divert you from your way. But this is to no man but to him that will read him, and read him with attentive studious painfulness. Which constant desire whosoever hath in him, hath already passed half the hardness of the way, and therefore is beholding to the Philosopher but for the other half. Nay truly, learned men have learnedly thought that where once reason hath so much over-mastered passion as that the mind hath a free desire to do well, the inward light each mind hath in itself is as good as a Philosopher's book; seeing in nature we know it is well to do well, and what is well, and what is evil, although not in the words of Art, which Philosophers bestow upon us. For out of natural conceit the Philosophers drew it, but to be moved to do that which we know, or to be moved with desire to know, Hoc opus: Hic labor est.

Now therein of all Sciences (I speak still of 
humane, and according to the humane conceits) is our Poet the Monarch ${ }^{\mathbf{1 6}}$. For he doth not only show the way but giveth so sweet a prospect into the way as will entice any man to enter into it. Nay, he doth, as if your journey should lie through a fair Vineyard, at the first give you a cluster of Grapes: that, full of that taste, you may long to pass further. He beginneth not with obscure definitions, which must blur the margent with interpretations and load the memory with doubtfulness : but he cometh to you with words sent in delightful proportion, either accompanied with or prepared for the well-enchanting skill of Music; and with a tale, forsooth, he cometh unto you : with a tale which holdeth children from play and old men from the chimney corner. And, pretending no more, doth intend the winning of the mind from wickedness to virtue: even as the child is often brought to take most wholesome things, by hiding them in such other as have a pleasant taste: which if one should begin to tell them the nature of Aloes or Rhubarb they should receive, would sooner take their Physic at their ears than at their mouth. So is it in men (most of which are childish in the best things, till they be cradled in their graves), glad they will be to hear the tales of Hercules, Achilles, Cyrus, and Aeneas : and, hearing them, must needs hear the right description of wisdom, valour and justice ; which, if they had been barely, that is to say, philoso-

16 The proposition stated on $\mathrm{p} .5 \mathrm{I}$ is now proved. See note I i in loc. Sidney next goes on to the delight of poetry. 


\section{An Apology for Poetry}

phically set out, they would swear they be brought to school again.

That imitation, whereof Poetry is, hath the most conveniency to Nature of all other, insomuch that, as Aristotle saith, those things which in themselves are horrible, as cruel battles, unnatural Monsters, are made in poetical imitation delightful. Truly I have known men that even with reading Amadis de Gaule (which God knoweth wanteth much of a perfect Poesy) have found their hearts moved to the exercise of courtesy, liberality, and especially courage.

Who readeth Aeneas carrying old Anchises on his back that wisheth not it were his fortune to perform so excellent an act? Whom do not the words of Turnus move?-the tale of Turnus, having planted his image in the imagination,

Fugientem hæc terra videbit, Usque adeone mori miserum est?

Where the Philosophers as they scorn to delight, so must they be content little to move: saving wrangling, whether Virtue be the chief or the only good: whether the contemplative or the active life do excel: which Plato and Boethius well knew, and therefore made Mistress Philosophy very often borrow the masking raiment of Poesy. For even those hard-hearted evil men who think virtue a school name, and know no other good but indulgere genio, and therefore despise the austere admonitions of the Philosopher, and feel not the inward reason they stand upon; yet will be content to be delighted: which is all the goodfellow Poet 
seemeth to promise : and so steal to see the form of goodness (which seen they cannot but love) ere themselves be aware, as if they took a medicine of cherries. Infinite proofs of the strange effects of this poetical invention might be alleged, only two shall serve, which are so often remembered, as I think all men know them.

The one of Menenius Agrippa, who when the whole people of Rome had resolutely divided themselves from the Senate, with apparent show of utter ruin: though he were (for that time) an excellent Orator, came not among them upon trust of figurative speeches or cunning insinuations: and much less, with far-set Maxims of Philosophy which (especially if they were Platonic) they must have learned Geometry before they could well have conceived: but, forsooth, he behaves himself like a homely and familiar Poet. He telleth them a tale, that there was a time when all the parts of the body made a mutinous conspiracy against the belly, which they thought devoured the fruits of each other's labour: they concluded they would let so unprofitable a spender starve. In the end, to be short (for the tale is notorious, and as notorious that it was a tale), with punishing the belly they plagued themselves. This applied by him wrought such effect in the people as I never read that ever words brought forth but then, so sudden and so good an alteration; for upon reasonable conditions, a perfect reconcilement ensued. The other is of Nathan the Prophet, who when the holy David had so far forsaken God as to confirm adultery with murder ; when he was to do the tenderest office of a friend 
in laying his own shame before his eyes, sent by God to call again so chosen a servant, how doth he it ? but by telling of a man, whose beloved Lamb was ungratefully taken from his bosom: the application most divinely true, but the discourse itself feigned : which made David (I speak of the second and instrumental cause), as in a glass, to see his own filthiness, as that heavenly Psalm of mercy well testifieth.

By these therefore examples and reasons I think it may be manifest that the Poet with that same hand of delight doth draw the mind more effectually than any other Art doth, and so a conclusion not unfitly ensueth ${ }^{17}$ : that, as virtue

17 Sidney's meaning is that the most efficacious incentive to virtuous action is not derived from the cold maxims of philosophy, but from the inspiring illustrations of the poets. George Herbert, the devout Anglican poet of the seventeenth century, expresses a similar sentiment in his Church Porch, where he writes:

A verse may find him whom a sermon flies, And turn delight into a sacrifice,

thus converting the delight which Sidney properly emphasizes as the aim of poetry to a moral purpose. That poetry should affect conduct is a sound principle of criticism, though Sidney and these early critics present the argument somewhat raggedly. They have not yet formulated the general proposition that religion, poetry and philosophy speak different languages, pursue truth along different roads, and employ each a different medium of expression. Matthew Arnold's paper on 'The Study of Poetry,' in his Essays in Criticism, should be consulted at this point, together with a sentence from his Literature and Dogma: "The language of the Bible is literary, not scientific language ; language thrown out at an object of consciousness not fully grasped, which inspired emotion. Evidently, if the object be one not fully to be grasped, and one to inspire emotion, the language of figure and feeling will satisfy us better about it, will cover more of

E.L.

E 
is the most excellent resting-place for all worldly learning to make its end of, so Poetry, being the most familiar to teach it, and most princely to move towards it, in the most excellent work, is the most excellent workman. But I am content, not only to decipher it by its works (although works, in commendation or dispraise, must ever hold a high authority), but more narrowly will examine its parts : so that (as in a man) though altogether may carry a presence full of majesty and beauty, perchance in some one defectious piece we may find a blemish. Now, in its parts, kinds, or Species (as you list to term them), it is to be noted, that some Poesies have coupled together two or three kinds, as Tragical and Comical, whereupon is risen the Tragi-comical. Some in the like manner have mingled Prose and Verse, as Sanazzar and Boetius. Some have mingled matters Heroical and Pastoral. But that cometh all to one in this question, for, if severed they be good, the conjunction cannot be hurtful. Therefore perchance forgetting some, and leaving some as needless to be remembered, it shall not be amiss in a word to cite the special kinds, to see what faults may be found in the right use of them ${ }^{18}$.

what we seek to express, than the language of literal fact and science. The language of science about it will be below what we feel to be the truth'.

18 The value of the following paragraphs is largely discounted by the fact that they are couched in a tone of apology. Among other mischief wrought by Stephen Gosson in his pamphlet on The School of Abuse is the necessity under which Sidney felt himself placed and under which he consciously laboured, of defending poetry instead of criticizing it. He had to repel destructive criticism instead of writing constructive criticism. This 
Is it then the Pastoral Poem which is misliked ? (for perchance, where the hedge is lowest, they will soonest leap over). Is the poor pipe disdained, which sometimes out of Melibœus' mouth can show the misery of people under hard Lords or ravening Soldiers? And, again, by Tityrus what blessedness is derived to them that lie lowest from the goodness of them that sit highest? Sometimes, under the pretty tales of Wolves and Sheep, can include the whole considerations of wrong doing and patience. Sometimes show that contention for trifles can get but a trifling victory. Where perchance a man may see that even Alexander and Darius, when they strove who should be cock of this world's dunghill, the benefit they got, was, that the after-livers may say,

Hæc memini et victum frustra contendere Thirsin :

Ex illo Coridon, Coridon est tempore nobis.

Or is it the lamenting Elegiac, which in a kind heart would move rather pity than blame, who bewails with the great Philosopher Heraclitus the weakness of mankind, and the wretchedness of the world : who surely is to be praised, either for compassionate accompanying just causes of lamentation, or for rightly pointing out how weak be the passions of wofulness. Is it the bitter but

source of confusion gives an antiquated air to such phrases as 'is it the pastoral poem which is misliked ?', 'the elegiac in a kind heart would move rather pity than blame', 'the heroical, whose very name should daunt all backbiters', etc. It is not difficult, however, to disengage the permanent elements from these marks of ephemeral controversy. 
wholesome Iambic, which rubs the galled mind, in making shame the trumpet of villany, with bold and open crying out against naughtiness; or the Satiric, who

Omne vafer vitium ridenti tangit amico?

who sportingly never leaveth, until he make a man laugh at folly, and, at length ashamed, to laugh at himself: which he cannot avoid without avoiding the folly. Who while

\section{Circum præcordia ludit}

giveth us to feel how many head-aches a passionate life bringeth us to. How when all is done,

Est ulubris animus si nos non deficit æquus ?

No: perchance it is the Comic whom naughty Play-makers and Stage-keepers have justly made odious. To the argument of abuse ${ }^{19}$, I will answer after. Only thus much now is to be said, that the Comedy is an imitation of the common errors of our life which he representeth in the most ridiculous and scornful sort that may be. So that it is impossible that any beholder can be content to be such a one.

Now, as in Geometry the oblique must be known as well as the right; and, in Arithmetic, the odd as well as the even, so in the actions of our life, who seeth not the filthiness of evil wanteth a great foil to perceive the beauty of virtue ${ }^{20}$. This doth

19 A nearly direct reference to The School of Abuse.

20 This is a sound principle of morals and of art. The 


\section{An Apology for Poetry}

the Comedy handle so in our private and domestic matters that, with hearing it, we get as it were an experience what is to be looked for of a niggardly Demea : of a crafty Danus : of a flattering Gnato : of a vainglorious Thraso: and not only to know what effects are to be expected, but to know who be such, by the signifying badge given them by the Comedian. And little reason hath any man to say that men learn evil by seeing it so set out : since, as I said before, there is no man living but, by the force truth hath in nature, no sooner seeth these men play their parts, but wisheth them in Pistrinum: although perchance the sack of his own faults lie so behind his back that he seeth not himself dance the same measure: whereto yet nothing can more open his eyes, than to find his own actions contemptibly set forth. So that the right use of Comedy will (I think) by nobody be blamed, and much less of the high and excellent Tragedy, that openeth the greatest wounds, and showeth forth the Vicers that are covered with Tissue : that maketh Kings fear to be Tyrants, and Tyrants manifest their tyrannical humours: that with stirring the affects of admiration and commiseration teacheth the uncertainty of this world, and upon how weak foundations gilded roofs are builded. That maketh us know

Qui sceptra sævus duro imperio regit

Timet timentes, metus in auctorem redit.

moral canon is stated in Ps. viii. 5 : 'Depart from evil and do good ' ; a statement of the aesthetic canon will be found in the Discourses of Sir Joshua Reynolds : 'It is in art as in morals : no character would inspire us with an enthusiastic admiration of his virtue if that virtue consisted 
But how much it can move Plutarch yieldeth a notable testimony, of the abominable Tyrant, Alexander Pherœus; from whose eyes a Tragedy well made and represented drew abundance of tears: who without all pity had murdered infinite numbers, and some of his own blood. So that he, that was not ashamed to make matters for Tragedies, yet could not resist the sweet violence of a Tragedy.

And if it wrought no further good in him, it was that he, in despite of himself, withdrew himself from harkening to that which might mollify his hardened heart. But it is not the Tragedy they do mislike : for it were too absurd to cast out so excellent a representation of whatsoever is most worthy to be learned. Is it the Lyric that most displeaseth, who with his tuned Lyre and well accorded voice giveth praise, the reward of virtue, to virtuous acts?, who gives moral precepts, and natural Problems, who sometimes raiseth up his voice to the height of the heavens in singing the lauds of the immortal God. Certainly I must confess my own barbarousness: I never heard the old song of Percy and Douglas, that I found not my heart moved more than with a Trumpet; and yet is it sung but by some blind Crowder ${ }^{21}$, with no rougher voice than rude style: which, being so evil apparelled in the dust and cobwebs of that uncivil age, what would it work trimmed in the gorgeous eloquence of Pindar? In Hungary I

only in an absence of vice. Simplicity, when so very inartificial as to seem to evade the difficulties of art, is a very suspicious virtue'.

21 Fiddler. 


\section{An Apology for Poetry}

have seen it the manner at all Feasts, and other such meetings, to have songs of their Ancestors' valour ; which that right Soldier-like Nation think the chiefest kindlers of brave courage. The incomparable Lacedæmonians did not only carry that kind of Music ever with them to the field, but even at home, as such songs were made, so were they all content to be the singers of them, when the lusty men were to tell what they did, the old men what they had done, and the young men what they would do. And where a man may say that Pindar many times praiseth highly victories of small moment, matters rather of sport than virtue : as it may be answered, it was the fault of the Poet, and not of the Poetry; so indeed, the chief fault was in the time and custom of the Greeks, who set those toys at so high a price, that Philip of Macedon reckoned a horse-race won at Olympus among his three fearful felicities. But as the inimitable Pindar ${ }^{22}$ often did, so is that kind most capable and most fit to awake the thoughts from the sleep of idleness, to embrace honourable enterprises.

There rests the Heroical, whose very name

22 Pindar's odes are not, perhaps, so popular now as then; in the eighteenth century poems were frequently cast in the form of 'Pindaric odes', e.g. by Gray and Collins. The irregular metrical licences were a great temptation. Wordsworth's Ode on the Intimations of Immortality, and Tennyson's On the Death of the Duke of Wellington are the most recent examples.

As to the 'matters rather of sport than virtue', modern England may be compared with ancient Greece in that aspect; and a parallel could be found in recent times to Philip of Macedon, who counted a 'winner' at a horserace as one of his three chief triumphs. 
think) should daunt all back-biters; for by what conceit can a tongue be directed to speak evil of that which draweth with it no less Champions than Achilles, Cyrus, Aeneas, Turnus, Tydeus, and Rinaldo?; who doth not only teach and move to a truth, but teacheth and moveth to the most high and excellent truth. Who maketh magnanimity and justice shine throughout all misty fearfulness and foggy desires. Who, if the saying of Plato and Tully be true, that who could see Virtue would be wonderfully ravished with the love of her beauty: this man sets her out to make her more lovely in her holiday apparel, to the eye of any that will deign not to disdain until they understand. But if anything be already said in the defence of sweet Poetry, all concurreth to the maintaining the Heroical, which is not only a kind, but the best and most accomplished kind of Poetry. For as the image of each action stirreth and instructeth the mind, so the lofty image of such Worthies most inflameth the mind with desire to be worthy, and informs with counsel how to be worthy. Only let Aeneas be worn in the tablet of your memory, how he governeth himself in the ruin of his Country, in the preserving his old Father, and carrying away his religious ceremonies: in obeying the gods' commandment ${ }^{23}$ to leave Dido, though not only all passionate kindness, but even the human consideration of virtuous gratefulness would have craved other of him. How in storms, how in

23 Multa gemens, magnoque animum labefactus amore, jussa tamen divom exsequitur. Aeneid iv. 395-6.

The whole passage, with its magnificent exaltation of the ancient virtue of piety, should be consulted. 


\section{An Apology for Poetry}

sports, how in war, how in peace, how a fugitive, how victorious, how besieged, how besieging, how to strangers, how to allies, how to enemies, how to his own : lastly, how in his inward self, and how in his outward government. And I think, in a mind not prejudiced with a prejudicating humour, he will be found in excellency fruitful : yea, even as Horace saith

Melius Chrisippo et Crantore.

But truly I imagine, it falleth out with these Poet-whippers as with some good women, who often are sick, but in faith they cannot tell where. So the name of Poetry is odious to them, but neither its cause, nor effects, neither the sum that contains it, nor the particularities descending from it, give any fast handle to their carping dispraise. Since then Poetry is of all humane learning the most ancient, and of most fatherly antiquity, as from whence other learnings have taken their beginnings : since it is so universal that no learned Nation doth despise it, nor no barbarous Nation is without it : since both Roman and Greek gave divine names unto it : the one of prophesying, the other of making. And that indeed, that name of making is fit for it; considering that, whereas other Arts retain themselves within their subject, and receive, as it were, their being from it: the Poet only bringeth his own stuff, and doth not learn a conceit out of a matter, but maketh matter for a conceit : Since neither his description nor his end containeth any evil, the thing described cannot be evil : Since his effects be so good as to 
teach goodness and to delight the learners: Since therein (namely in moral doctrine, the chief of all knowledges) he doth not only far pass the Historian, but for instructing is well nigh comparable to the Philosopher: and for moving, leaves him behind him: Since the holy scripture (wherein there is no uncleanness) hath whole parts in it poetical, and that even our Saviour Christ vouchsafed to use the flowers of it : Since all his kinds are not only in their united forms but in their fevered dissections fully commendable, I think (and think, I think, rightly) the Laurel crown appointed for triumphing Captains doth worthily (of all other learnings) honour the Poets' triumph. But because we have ears as well as tongues, and that the lightest reasons that may be will seem to weigh greatly, if nothing be put in the counterbalance : let us hear and, as well as we can, ponder what objections may be made against this Art, which may be worthy either of yielding or answering.

First truly I note, not only in these Mysomousoi Poet-haters, but in all that kind of people who seek a praise by dispraising others, that they do prodigally spend a great many wandering words in quips and scoffs; carping and taunting at each thing, which by stirring the spleen may stay the brain from a thorough beholding the worthiness of the subject.

Those kind ${ }^{24}$ of objections, as they are full of very idle easiness, since there is nothing of so sacred

24 Correct grammar requires that kind. "Those kind of' things is still a vulgar error to-day. 
a majesty but that an itching tongue may rub itself upon it: so deserve they no other answer but instead of laughing at the jest to laugh at the jester. We know a playing wit can praise the discretion of an Ass ; the comfortableness of being in debt, and the jolly commodity of being sick of the plague. So of the contrary side, if we will turn Ovid's verse,

Ut lateat virtus proximitate mali,

that good lie hid in nearness of the evil, Agrippa will be as merry in showing the vanity of Science, as Erasmus was in commending of folly. Neither shall any man or matter escape some touch of these smiling railers. But for Erasmus and Agrippa, they had another foundation than the superficial part would promise. Marry, these other pleasant Fault-finders, who will correct the Verb before they understand the Noun, and confute others' knowledge before they confirm their own, I would have them only remember that scoffing cometh not of wisdom. So that the best title in true English they get with their merriments is to be called good fools : for so have our grave Forefathers ever termed that humorous kind of jesters : but that which giveth greatest scope to their scorning humours, is rhyming and versing. It is already said (and as I think truly said) it is not rhyming and versing that maketh Poesy. One may be a Poet without versing and a versifier without Poetry. But yet, presuppose it were inseparable (as indeed it seemeth Scaliger judgeth) truly it were an inseparable commendation. For if Oratio next to 
Ratio, Speech next to Reason, be the greatest gift bestowed upon mortality, that cannot be praiseless which doth most polish that blessing of speech, which considers each word not only (as a man may say) by its forcible quality, but by its best measured quantity, carrying even in themselves a Harmony : (without perchance Number, Measure, Order, Proportion, be in our time grown odious). But lay aside the just praise it hath by being the only fit speech for Music (Music I say, the most divine striker of the senses): thus much is undoubtedly true, that if reading be foolish without remembering, memory being the only treasurer of knowledge, those words which are fittest for memory are likewise most convenient for knowledge.

Now, that Verse far exceedeth Prose in the knitting up of the memory, the reason is manifest. The words (besides their delight which hath a great affinity to memory) being so set as one word cannot be lost but the whole work fails: which accuseth itself, calleth the remembrance back to itself, and so most strongly confirmeth it; besides one word so as it were begetting another, as be it in rhyme or measured verse, by the former a man shall have a near guess to the follower: lastly, even they that have taught the Art of memory have showed nothing so apt for it as a certain room divided into many places well and thoroughly known. Now, that hath the verse in effect perfectly: every word having its natural seat, which seat must needs make the words remembered. But what needeth more in a thing so known to all men ? Who is it that ever was a scholar that doth not carry away some verses of 
Virgil, Horace, or Cato, which in his youth he learned, and even to his old age serve him for hourly lessons? But the fitness it hath for memory is notably proved by all delivery of Arts : wherein for the most part, from Grammar, to Logic, Mathematic, Physic, and the rest, the rules chiefly necessary to be borne away are compiled in verses. So that, verse being in itself sweet and orderly, and being best for memory, the only handle of knowledge, it must be in jest that any man can speak against it.

Now then go we to the most important imputations laid to the poor Poets, for aught I can yet learn, they are these : first, that there being many other more fruitful knowledges, a man might better spend his time in them than in this. Secondly, that it is the mother of lies. Thirdly, that it is the Nurse of abuse, infecting us with many pestilent desires: with a Siren's sweetness drawing the mind to the Serpent's tale of sinful fancy. And herein especially Comedies give the largest field to err, as Chaucer saith : how both in other Nations and in ours, before Poets did soften us, we were full of courage, given to martial exercises; the pillars of manlike liberty, and not lulled asleep in shady idleness with Poets' pastimes. And lastly, and chiefly, they cry out with an open mouth, as if they outshot Robin Hood, that Plato banished them out of his Commonwealth. Truly, this is much, if there be much truth in it. First to the first : that a man might better spend his time, is a reason indeed : but it doth (as they say) but petere principium : for if it be as I affirm, that no learning is so good as that which teacheth and moveth to 
virtue; and that none can both teach and move thereto so much as Poetry : then is the conclusion manifest, that Ink and Paper cannot be to a more profitable purpose employed. And certainly, though a man should grant their first assumption, it should follow (methinks) very unwillingly that good is not good because better is better. But I still and utterly deny that there is sprung out of earth a more fruitful knowledge. To the second therefore, that they should be the principal liars, I answer paradoxically, but truly-I think trulythat of all writers under the sun the Poet is the least liar: and though he would, as a Poet can scarcely be a liar, the Astronomer, with his cousin the Geometrician, can hardly escape, when they take upon them to measure the height of the stars.

How often, think you, do the Physicians lie, when they aver things good for sicknesses which afterwards send Charon a great number of souls drowned in a potion before they come to his Ferry? And no less of the rest which take upon them to affirm. Now, for the Poet, he nothing affirms, and therefore never lieth. For, as I take it, to lie is to affirm that to be true which is false. So as the other Artists, and especially the Historian, affirming many things, can in the cloudy knowledge of mankind hardly escape from many lies. But the Poet (as I said before) never affirmeth. The Poet never maketh any circles about your imagination to conjure you to believe for true what he writes. He citeth not authorities of other Histories, but, even for his entry, calleth the sweet Muses to inspire into him a good invention : in troth, not labouring to tell you what is, or is 
not, but what should or should not be : and therefore, though he recount things not true, yet because he telleth them not for true, he lieth not, without we will say that Nathan lied in his speech, before alleged to David. Which as a wicked man durst scarce say, so think I none so simple would say that Aesop lied in the tales of his beasts : for who thinks that Aesop wrote it for actually true were well worthy to have his name chronicled among the beasts he writeth of ${ }^{25}$.

What child is there that, coming to a Play, and seeing Thebes written in great letters upon an old door, doth believe that it is Thebes? If then a man can arrive at that child's age to know that the Poets' persons and doings are but pictures what should be, and not stories what have been, they will never give the lie to things not affirmatively but allegorically and figuratively written. And therefore, as in History, looking for truth, they go away full fraught with falsehood : so in Poetry, looking for fiction, they shall use the narration but as an imaginative groundplot of a profitable invention.

But hereto is replied that the Poets give names to men they write of, which argueth a conceit of an actual truth, and so, not being true, proves a falsehood. And doth the Lawyer lie then, when

25 On the question of poetic truth, see note 17, p. 65 , supra. See also the section 'Poetic Truth' in Magnus, Introduction to Poetry (Murray), and Beeching, The Study of Poetry (Univ. Press, Cambridge). These paragraphs are full of Gosson, and Sidney's tone is too apologetic for the dignity of his theme, though in the word 'figuratively' below he anticipates Matthew Arnold's dictum about 'the language of figure and feeling '. 
under the names of John-a-stile and John-a-noakes he puts his case ${ }^{26}$ ? But that is easily answered. Their naming of men is but to make their picture the more lively, and not to build any history: painting men, they cannot leave men nameless. We see we cannot play at Chess but that we must give names to our Chess-men ; and yet methinks he were a very partial Champion of truth that would say we lied for giving a piece of wood the reverend title of a Bishop. The Poet nameth Cyrus or Aeneas no other way than to show what men of their fames, fortunes and estates should do.

Their third is, how much it abuseth men's wit, training it to wanton sinfulness and lustful love : for indeed that is the principal, if not the only abuse I can hear alleged. They say, the Comedies rather teach than reprehend amorous conceits. They say, the Lyric is larded with passionate Sonnets. The Elegiac weeps the want of his mistress. And that even to the Heroical Cupid hath ambitiously climbed. Alas, Love! I would thou couldst as well defend thyself as thou canst offend others. I would those on whom thou dost attend could either put thee away or yield good reason why they keep thee. But grant love of beauty to be a beastly fault (although it be very hard, since only man, and no beast, hath that gift, to discern beauty); grant that lovely name of Love to deserve all hateful reproaches (although even some of my Masters the Philosophers spent a good deal of their Lamp-oil in setting forth the

26 The 'John Doe' and 'John Roe' of modern legal fiction. 
excellence of it); grant, I say, whatsoever they will have granted; that not only love, but lust, but vanity, but (if they list) scurrility possesseth many leaves of the Poets' books : yet think I, when this is granted, they will find their sentence may with good manners put the last words foremost : and not say that Poetry abuseth man's wit, but that man's wit abuseth Poetry.

For I will not deny but that man's wit may make Poesy (which should be Eikastike, which some learned have defined figuring forth good things) to be Phantastike: which doth, contrariwise, infect the fancy with unworthy objects. As the Painter that should give to the eye either some excellent perspective or some fine picture, fit for building or fortification : or containing in it some notable example, as Abraham sacrificing his son Isaac, Judith killing Holofernes, David fighting with Goliath, may leave those, and please an ill-pleased eye with wanton shows of better hidden matters. But what, shall the abuse of a thing make the right use odious? Nay truly, though I yield that Poesy may not only be abused, but that being abused, by the reason of its sweetcharming force, it can do more hurt than any other Army of words : yet shall it be so far from concluding that the abuse should give reproach to the abused, that contrariwise it is a good reason that, whatsoever being abused doth most harm, being rightly used (and upon the right use each thing conceiveth his title) doth most good.

Do we not see the skill of Physic (the best rampire $^{27}$ to our often-assaulted bodies), being 27 Rampart.

E.L. 
abused, teach poison the most violent destroyer ? Doth not knowledge of Law, whose end is to even and right all things, being abused, grow the crooked fosterer of horrible injuries? Doth not (to go to the highest) God's word abused breed heresy ? and His Name abused become blasphemy? Truly, a needle cannot do much hurt, and as truly (with leave of Ladies be it spoken) it cannot do much good. With a sword thou mayest kill thy Father, and with a sword thou mayest defend thy Prince and Country. So that, as in their calling Poets the Fathers of lies they say nothing, so in this their argument of abuse, they prove the commendation.

They allege herewith that, before Poets began to be in price, our Nation hath set their hearts' delight upon action, and not upon imagination : rather doing things worthy to be written than writing things fit to be done. What that beforetime was I think scarcely Sphinx can tell : since no memory is so ancient that hath the precedence of Poetry. And certain it is that in our plainest homeliness, yet never was the Albion Nation without Poetry. Marry, this argument though it be levelled against Poetry, yet is it indeed a chain-shot against all learning, or bookishness, as they commonly term it. Of such mind were certain Goths, of whom it is written that, having in the spoil of a famous City taken a fair library, one hangman (belike fit to execute the fruits of their wits) who had murdered a great number of bodies, would have set fire on it: ' No', said another very gravely, 'take heed what you do, for while they are busy about these toys, we shall with more leisure conquer their Countries'. 


\section{An Apology for Poetry}

This indeed is the ordinary doctrine of ignorance, and many words sometimes I have heard spent in it : but because this reason is generally against all learning as well as Poetry; or, rather, all learning but Poetry: because it were too large a digression to handle or at least too superfluous (since it is manifest that all government of action is to be gotten by knowledge and knowledge best, by gathering many knowledges, which is reading), I only with Horace to him that is of that opinion

Jubeo stultum esse libenter;

for as for Poetry itself, it is the freest from this objection. For Poetry is the companion of the Camps.

I dare undertake, Orlando Furioso or honest King Arthur will never displease a Soldier: but the quiddity of Ens and Prima materia will hardly agree with a Corslet: and therefore, as I said in the beginning, even Turks and Tartars are delighted with Poets. Homer, a Greek, flourished before Greece flourished. And if to a slight conjecture a conjecture may be opposed: truly it may seem that as by him their learned men took almost their first light of knowledge, so their active men received their first motions of courage. Only Alexander's example may serve, who by Plutarch is accounted of such virtue that Fortune was not his guide but his foot-stool; whose acts speak for him, though Plutarch did not: indeed, the Phœnix of warlike Princes. This Alexander left his Schoolmaster, living Aristotle, behind him, but took dead Homer with him: he put the 
Philosopher Calisthenes to death for his seeming philosophical, indeed mutinous, stubbornness. But the chief thing he ever was heard to wish for was that Homer had been alive. He well found he received more bravery of mind by the pattern of Achilles than by hearing the definition of Fortitude : and, therefore, if Cato misliked Fulvius, for carrying Ennius with him to the field, it may be answered that, if Cato misliked it, the noble Fulvius liked it, or else he had not done it : for it was not the excellent Cato Uticensis (whose authority I would much more have reverenced) but it was the former : in truth, a bitter punisher of faults, but else, a man that had never well sacrificed to the Graces. He misliked and cried out upon all Greek learning, and yet being eighty years old began to learn it, belike fearing that Pluto understood not Latin. Indeed, the Roman laws allowed no person to be carried to the wars but he that was in the Soldiers' roll: and therefore, though Cato misliked his unmustered person, he misliked not his work. And if he had, Scipio Nasica, judged by common consent the best Roman, loved him. Both the other Scipio Brothers, who had by their virtues no less surnames than of Asia and Africa, so loved him that they caused his body to be buried in their Sepulchre. So that Cato, his authority being but against his person, and that answered, with so far greater than himself, is herein of no validity.

But now indeed my burthen is great; now Plato's name is laid upon me, whom I must confess, of all Philosophers, I have ever esteemed most worthy of reverence, and with great reason, since 


\section{An Apology for Poetry}

of all Philosophers he is the most poetical. Yet il he will defile the Fountain out of which his flowing streams have proceeded, let us boldly examine with what reasons he did it. First truly, a man might maliciously object that Plato being a Philosopher was a natural enemy of Poets : for indeed, after the Philosophers had picked out of the sweet mysteries of Poetry the right discerning true points of knowledge, they forthwith putting it in method, and making a School-art of that which the Poets did only teach by a divine delightfulness, beginning to spurn at their guides, like ungrateful Prentices, were not content to set up shops for themselves, but sought by all means to discredit their Masters. Which by the force of delight being barred them, the less they could overthrow them the more they hated them. For indeed, they found for Homer seven Cities strove who should have him for their Citizen: where many Cities banished Philosophers, as not fit members to live among them. For only repeating certain of Euripides' verses many Athenians had their lives saved of the Syracusans, when the Athenians themselves thought many Philosophers unworthy to live.

Certain Poets, as Simonides and Pindar had so prevailed with Hiero the First, that of a Tyrant they made him a just King, where Plato could do so little with Dionysius, that he himself, of a Philosopher was made a slave. But who should do thus, I confess, should requite the objections made against Poets, with like cavillation against Philosophers, as likewise one should do that should bid one read Phadrus, or Symposium in 
Plato, or the discourse of love in Plutarch, and see whether any Poet do authorize abominable filthiness as they do. Again, a man might ask out of what Commonwealth Plato did banish them, insooth, thence where he himself alloweth community of women. So that belike this banishment grew not for effeminate wantonness, since little should poetical Sonnets be hurtful, when a man might have what woman he listed. But I honour philosophical instructions, and bless the wits which bred them : so that they be not abused, which is likewise stretched to Poetry.

St. Paul himself (who yet for the credit of Poets allegeth twice two Poets, and one of them by the name of a Prophet) setteth a watchword upon Philosophy, indeed upon the abuse. So doth Plato upon the abuse, not upon Poetry. Plato found fault that the Poets of his time filled the world with wrong opinions of the Gods, making light tales of that unspotted essence; and therefore would not have the youth depraved with such opinions. Herein may much be said, let this suffice: the Poets did not induce such opinions, but did imitate those opinions already induced. For all the Greek stories can well testify that the very religion of that time stood upon many and many-fashioned Gods, not taught so by the Poets, but followed, according to their nature of imitation. Who list may read in Plutarch the discourses of Isis and Osiris of the cause why Oracles ceased, of the divine providence: and see whether the Theology of that nation stood not upon such dreams, which the Poets indeed superstitiously observed, and truly (since they had not the light of 


\section{An Apology for Poetry}

Christ) did much better in it than the Philosophers who, shaking off superstition, brought in Atheism. Plato therefore (whose authority I had much rather justly construe than unjustly resist) meant not in general of Poets, in those words of which Julius Scaliger ${ }^{28}$ saith Qua authoritate, barbari quidam, atque hispidi, abuti velint, ad Poetas $e$ republica exigendos: but only meant, to drive out those wrong opinions of the Deity (whereof now, without further law, Christianity hath taken away all the hurtful belief) perchance (as he thought) nourished by the then esteemed Poets. And a man need go no further than to Plato himself to know his meaning : who in his Dialogue called Ion giveth high and rightly divine commendation to Poetry. So that Plato, banishing the abuse, not the thing, not banishing it, but giving due honour unto it, shall be our Patron, and not our adversary. For indeed I had much rather (since truly I may do it) show their mistaking of Plato (under whose Lion's skin they would make an Ass-like braying against Poesy) than go about to overthrow his authority, whom the wiser a man is, the more just cause he shall find to have in admiration : especially since he attributeth unto Poesy more than myself do; namely, to be a very inspiring of a divine force far above man's wit; as in the aforenamed Dialogue is apparent ${ }^{29}$.

28 This is Julius Caesar Scaliger (1484-1558), a celebrated critic of the Renaissance, the father of Joseph Justus Scaliger (I 540-1609).

${ }^{29}$ The whole argument in the foregoing paragraph as to Plato's expulsion of the poets from his ideal Republic is 
Of the other side, who would show the honours have been by the best sort of judgments granted them, a whole Sea of examples would present themselves. Alexanders, Caesars, Scipios, all favourers of Poets. Lælius, called the Roman Socrates, himself a Poet: so that part of Heautontimorumenon in Terence was supposed to be made by him. And even the Greek Socrates, whom Apollo confirmed to be the only wise man, is said to have spent part of his old time in putting Aesop's fables into verses. And therefore, full evil should it become his scholar Plato to put such words in his Master's mouth against Poets. But what need more? Aristotle writes the Art of Poesy: and why if it should not be written ? Plutarch teacheth the use to be gathered of them, and how if they should not be read? And who reads Plutarch's either history or philosophy shall find he trimmeth both their garments with gards of Poesy. But I list not to defend Poesy with the help of her underling, Historiography. Let it suffice that it is a fit soil for praise to dwell upon: and what dispraise may set upon it is

absolutely correct and admirably stated. Plato's teaching on the subject must be sought by bringing together the passages in Republic, Books III and X, with the treatment of cognate subjects in Gorgias, Symposium and Phadrus. In one sense Plato-like Stephen Gossonwas writing in an age which encouraged prejudice against poetry. 'The poetry of the time,' says Prof. Campbell, 'appeared adapted to perpetuate those very features in the lives of his countrymen which Plato earnestly sought to remove ; superstition on the one hand, frivolity and unlimited caprice on the other ... The noble art of tragedy had been infected with sophistry and rhetoric, and had degenerated into something showy and unreal. (Plato's Republic, Murray, p. 87). 
either easily overcome, or transformed into just commendation. So that, since the excellences of it may be so easily and so justly confirmed, and the low-creeping objections so soon trodden down; it not being an Art of lies, but of true doctrine: not of effeminateness, but of notable stirring of courage: not of abusing man's wit, but of strengthening man's wit: not banished, but honoured by Plato: let us rather plant more Laurels for to engarland our Poets' heads (which honour of being laureate as, besides them, only triumphant Captains wear, is a sufficient authority to show the price they ought to be had in) than suffer the ill-savouring breath of such wrongspeakers once to blow upon the clear springs of Poesy.

But since I have run so long a career in this matter, methinks, before I give my pen a full stop, it shall be but a little more lost time, to inquire why England (the Mother of excellent minds) should be grown so hard a step-mother to Poets, who certainly in wit ought to pass all other : since all only proceedeth from their wit, being indeed makers of themselves, not takers of others. How can I but exclaim,

Musa mihi causas memora, quo numine læso.

Sweet Poesy, that hath anciently had Kings, Emperors, Senators, great Captains, such, as besides a thousand others, David, Adrian, Sophocles Germanicus, not only to favour Poets, but to be Poets. And, of our nearer times, can present for her Patrons a Robert, King of Sicily, the great 
king Francis of France, King James of Scotland. Such Cardinals as Bembus and Bibiena. Such famous Preachers and Teachers as Beza and Melancthon. So learned Philosophers as Fracastorius and Scaliger. So great Orators as Pontanus and Muretus. So piercing wits as George $\mathrm{Bu}$ chanan ${ }^{30}$. So grave Counsellors, as besides many, but before all, that Hospitali of France: than whom (I think) that Realm never brought forth a more accomplished judgment : more firmly builded upon virtue. I say these, with numbers of others, not only to read others' Poesies, but to poetize for others' reading, that Poesy thus embraced in all other places should only find in our time a hard welcome in England, I think the very earth lamenteth it, and therefore decketh our Soil with fewer Laurels than it was accustomed. For heretofore, Poets have in England also flourished. And which is to be noted, even in those times, when the trumpet of Mars did sound loudest. And now that an over-faint quietness should

30 George Buchanan (1506-1582) was a famous name in Sidney's day, though its then bearer is almost forgotten now. He was a Scotsman, who was imprisoned at St. Andrews at the instance of Cardinal Beaton for his satires on the clergy, said to have been inspired by James $\mathrm{V}$ of Scotland. He escaped to France, and was imprisoned there by the Inquisition. Eventually he returned to Scotland, professed the Protestant faith, and became Principal of St. Leonard's College, St. Andrews I5661570. Later he lived in England as secretary to the Regent Moray's commissioners, and wrote pamphlets attacking the party which assassinated him. Buchanan was tutor to James VI, afterwards James I of England, and wrote a satire on Queen Mary of Scotland. His Rerum Scoticarum Historia, I582, was a leading authority for Scottish history. 
seem to strew the house for Poets, they are almost in as good reputation as the Mountebanks at Venice $^{31}$. Truly even that, as of the one side, it giveth great praise to Poesy which like Venus (but to better purpose), hath rather be troubled in the net with Mars than enjoy the homely quiet of Vulcan: so serves it for a piece of a reason, why they are less grateful to idle England, which now can scarce endure the pain of a pen. Upon this necessarily followeth that base men with servile wits undertake it: who think it enough if they can be rewarded of the Printer. And so as Epaminondas is said, with the honour of his virtue, to have made an office, by his exercising it, which before was contemptible, to become highly respected: so these, no more but setting their names to it, by their own disgracefulness, disgrace the most graceful Poesy. For now, as if all the Muses were got with child, to bring forth bastard Poets, without any commission, they do post over the banks of Helicon, till they make the readers more weary than Post-horses: while in the meantime they,

\section{Quis meliore luto finxit præcordia Titan,}

are better content to suppress the out-flowing of their wit, than by publishing them to be accounted Knights of the same order. But I, that before, ever I durst aspire unto the dignity, am admitted

31 It is curious to read of this quiescence of poetry in the years immediately preceding Spenser, Marlowe, Shakespeare. The Shepherd's Calendar (see p. 93) had already appeared. 
into the company of the Paper-blurrers, do find the very true cause of our wanting estimation is want of desert: taking upon us to be Poets, in despite of Pallas. Now, wherein we want desert were a thankworthy labour to express : but if I knew, I should have mended myself. But I, as I never desired the title, so have I neglected the means to come by it ${ }^{32}$. Only overmastered by some thoughts, I yielded an inky tribute unto them. Marry, they that delight in Poesy itself should seek to know what they do, and how they do; and especially look themselves in an unflattering Glass of reason, if they be inclinable unto it. For Poesy must not be drawn by the ears, it must be gently led, or rather, it must lead. Which was partly the cause that made the ancient-learned affirm it was a divine gift, and no human skill: since all other knowledges lie ready for any that hath strength of wit. A Poet no industry can make, if his own Genius be not carried unto it: and therefore is it an old Proverb, Orator fit; Poeta nascitur. Yet confess I always that, as the fertilest ground must be manured, so must the highest flying wit have a Dædalus to guide him. That Dædalus, they say, both in this, and in other, hath three wings, to bear itself up into the air of due commendation : that is, Art, Imitation, and Exercise. But these neither artificial rules, nor imitative patterns, we much cumber ourselves withal. Exercise indeed we do, but that very fore-backwardly, for where we should exercise to know, we exercise

32 Sidney objected to receive, unasked, the dedication of inferior verse. 
as having known: and so is our brain delivered of much matter, which never was begotten by knowledge. For, there being two principal parts, matter to be expressed by words, and words to express the matter, in neither we use Art, or Imitation, rightly. Our matter is Quodlibet indeed, though wrongly performing Ovid's verse.

Quicquid conabar dicere versus erit:

never marshalling it into an assured rank, that almost the readers cannot tell where to find themselves.

Chaucer undoubtedly did excellently in his Troilus and Cresseid; of whom truly I know not whether to marvel more, either that he in that misty time could see so clearly, or that we in this clear age walk so stumblingly after him. Yet had he great wants, fit to be forgiven, in so reverent antiquity. I account the Mirrour of Magistrates meetly furnished of beautiful parts; and in the Earl of Surrey's Lyrics many things tasting of a noble birth, and worthy of a noble mind. The Sheapheard's Kalender hath much Poetry in its Eclogues : indeed worthy the reading if I be not deceived. That same framing of its style to an old rustic language I dare not allow, since neither Theocritus in Greek, Virgil in Latin, nor Sanazar in Italian, did affect it ${ }^{33}$. Besides

33 Webbe (see below) has a better sense of Spenser's promise, as indicated in The Shepherd's Calendar. That Sidney 'dare not allow' the use of an old rustic language because Virgil and Theocritus did not affect it is a piece of criticism of no value which must in all probability be ascribed to the stilted rules of the Areopagus, a little club, or clique, of literary men, with the Cambridge scholar, Gabriel Harvey, at its head. The influence of the Areopa- 
these, do I not remember to have seen but few (to speak boldly) printed, that have poetical sinews in them : for proof whereof, let but most of the verses be put in Prose, and then ask the meaning ; and it will be found that one verse did but beget another, without ordering at the first what should be at the last : which becomes a confused mass of words, with a tingling sound of rhyme, barely. accompanied with reason.

Our Tragedies and Comedies (not without cause cried out against), observing rules neither of honest civility nor of skilful Poetry, excepting Gorboduc (again, I say, of those that I have seen), which notwithstanding, as it is full of stately speeches and well-sounding Phrases, climbing to the height of Seneca's style, and as full of notable morality, which it doth most delightfully teach; and so obtain the very end of Poesy: yet in troth it is very defectious in the circumstances; which grieveth me, because it might not remain as an exact model of all Tragedies. For it is faulty

gus is also and more clearly to be traced in the succeeding remarks about 'Aristotle's precept' for the drama. Sidney's insistence on the observance of the unities of time and place is a piece of peclantry which could not stand for a moment against the tide of dramatic genius by which English literature was shortly to be invaded. Shakespeare and Marlowe at the Mermaid Tavern cared as little for the tragic canons of the Areopagus as Spenser for the language which Virgil and Theocritus affected. It must be always borne in nind that Sidney was writing before-however shortly before-the rise of drama in his own country, and that, further, the sympathies of the Court to which he was attached were at that time chiefly attracted by the highly-wrought art of Lyly's Euphues and of his own Arcadia, and of pageants, masques, and so forth, though Queen lilizabeth later in her reign was a keen patron of the stage. 
both in place and time, the two necessary companions of all corporal actions. For where the stage should always represent but one place, and the uttermost time presupposed in it should be, both by Aristotle's precept and common reason, but one day: there is both many days, and many places, inartificially imagined. But if it be so in Gorboduc, how much more in all the rest ?, where you shall have Asia of the one side, and Africa of the other, and so many other underkingdoms, that the Player, when he cometh in, must ever begin with telling where he is : or else the tale will not be conceived. Now ye shall have three Ladies walk to gather flowers, and then we must believe the stage to be a Garden. By and by, we hear news of shipwreck in the same place, and then we are to blame if we accept it not for a Rock.

Upon the back of that comes out a hideous Monster, with fire and smoke, and then the miserable beholders are bound to take it for a Cave. While in the meantime two Armies fly in, represented with four swords and bucklers, and then what hard heart will not receive it for a pitched field ? ${ }^{\mathbf{3 4}}$ Now, of time they are much more liberal, for ordinary it is that two young Princes fall in love. After many traverses, she is got with child, delivered of a fair boy, he is lost, groweth a man, falls in love, and is ready to get another child, and all this in two hours' space: which how absurd it is in sense, even sense may imagine, and

${ }^{3 *}$ The development of stage-scenery has improved away this objection, but why it is more absurd to 'imagine' time than action is not stated. 'Princes' (just below) is a 
Art hath taught, and all ancient examples justified : and at this day, the ordinary Players in Italy will not err in. Yet will some bring in an example of Eunuchus in Terence that containeth matter of two days, yet far short of twenty years. True it is, and so was it to be played in two days, and so fitted to the time it set forth. And though Plautus hath in one place done amiss, let us hit with him, and not miss with him. But they will say, how then shall we set forth a story which containeth both many places, and many times? And do they not know that a Tragedy is tied to the laws of Poetry, and not of History?, not bound to follow the story, but having liberty, either to feign a quite new matter, or to frame the history to the most tragical conveniency. Again, many things may be told, which cannot be shown, if they know the difference betwixt reporting and representing. As for example, I may speak (though I am here) of Peru, and, in speech, digress from that to the description of Calicut: but in action I cannot represent it without Pacolet's horse : and so was the manner the Ancients took, by some Nuncius, to recount things done in former time, or other place. Lastly, if they will represent an history, they must not (as Horace saith) begin $A b$ ovo: but they must come to the principal point of that one action which they will represent. By example this will be best expressed. I have a story of young Polydorus, delivered for safety's sake, with great riches, by his Father Priam to Polymnestor, King of Thrace, in the Trojan war-

generic plural prince and princess. 
time. He after some years, hearing the overthrow of Priam, for to make the tre asure his own, murdereth the child: the body of the child is taken up to Hecuba; she the same day findeth a slight to be revenged most cruelly of the Tyrant. Where now would one of our Tragedy writers begin, but with the delivery of the child ? Then should he sail over into Thrace, and so spend I know not how many years, and travel numbers of places. But where doth Euripides? Even with the finding of the body, leaving the rest to be told by the spirit of Polydorus. This need no further to be enlarged, the dullest wit may conceive it. But besides these gross absurdities, how all their Plays be neither right Tragedies, nor right Comedies: mingling Kings and Clowns, not because the matter so carrieth it : but thrust in Clowns by head and shoulders, to play a part in majestical matters, with neither decency nor discretion ${ }^{35}$. So as neither the admiration and commiseration, nor the right sportfulness, is by their mongrel Tragi-comedy obtained. I know Apuleius did somewhat so, but that is a thing recounted with space of time, not represented in one moment : and I know the Ancients have one or two examples of Tragi-comedies, as Plautus hath Amphitrio. But if we mark them well, we shall find that they never, or very daintily, match Horn-pipes and Funerals. So falleth it out that, having indeed no right Comedy, in that comical

35 'This problem of 'decency' was settled once for all by the practice of Shakespeare, who mingles the tragic and comic elements in his plays-the kings and clownswithout respect to these theories of the stage.

E.L. 
part of our Tragedy, we have nothing but scurrility, unworthy of any chaste ears : or some extreme show of doltishness, indeed fit to lift up a loud laughter, and nothing else: where the whole tract of a Comedy should be full of delight, as the Tragedy should be still maintained, in a well-raised admiration. But our Comedians think there is no delight without laughter, which is very wrong, for though laughter may come with delight, yet cometh it not of delight: as though delight should be the cause of laughter, but well may one thing breed both together: nay, rather in themselves they have, as it were, a kind of contrariety : for delight we scarcely do, but in things that have a conveniency to ourselves, or to the general nature : laughter almost ever cometh of things most disproportioned to ourselves, and nature. Delight hath a joy in it, either permanent, or present. Laughter hath only a scornful tickling.

For example, we are ravished with delight to see a fair woman, and yet are far from being moved to laughter. We laugh at deformed creatures, wherein certainly we cannot delight. We delight in good chances, we laugh at mischances; we delight to hear the happiness of our friends, or Country; at which he were worthy to be laughed at, that would laugh; we shall contrarily laugh sometimes, to find a matter quite mistaken, and go down the hill against the bias, in the mouth of some such men, as for the respect of them, one shall be heartily sorry, yet he cannot choose but laugh; and so is rather pained than delighted with laughter. Yet deny I not, but that they may go well together, for as in Alexander's 
picture well set out, we delight without laughter, and in twenty mad Antics we laugh without delight: so in Hercules, painted with his great beard, and furious countenance, in woman's attire, spinning at Omphale's commandment, it breedeth both delight and laughter. For the representing of so strange a power in love procureth delight : and the scornfulness of the action stirreth laughter. But I speak to this purpose, that all the end of the comical part be not upon such scornful matters, as stirreth laughter only: but mixed with it, that delightful teaching which is the end of Poesy. And the great fault even in that point of laughter, and forbidden plainly by Aristotle, is that they stir laughter in sinful things ; which are rather execrable than ridiculous : or in miserable, which are rather to be pitied than scorned. For what is it to make folks gape at a wretched Beggar, or a beggarly Clown?, or against law of hospitality, to jest at strangers, because they speak not English so well as we do?; what do we learn, since it is certain

Nil habet infelix paupertas durius in se Quam quod ridiculos homines facit.

But rather a busy loving Courtier, a heartless threatening Thraso. A self-wise-seeming schoolmaster. An awry-transformed Traveller. These if we saw walk in stage names, which we play naturally, therein were delightful laughter, and teaching delightfulness: as in the other, the Tragedies of Buchanan, do justly bring forth a divine admiration. But I have lavished out too many words of this play matter. I do it because 
as they are excelling parts of Poesy, so is there none so much used in England, and none can be more pitifully abused. Which like an unmannerly Daughter, showing a bad education, causeth her mother Poesy's honesty to be called in question. Other sorts of Poetry almost have we none but that Lyrical kind of Songs and Sonnets: which, Lord, if he gave us so good minds, how well it might be employed, and with how heavenly fruit, both private and public, in singing the praises of the immortal beauty: the immortal goodness of that God who giveth us hands to write, and wits to conceive, of which we might well want words, but never matter, of which we could turn our eyes to nothing but we should ever have new budding occasions. But truly many of such writings as come under the banner of unresistable love, if I were a Mistress, would never persuade me they were in love: so coldly they apply fiery speeches, as men that had rather read Lovers' writings, and so caught up certain swelling phrases, which hang together (like a man which once told me, the wind was at North, West, and by South, because he would be sure to name winds enough), than that in truth they feel those passions, which easily (as I think) may be bewrayed by that same forcibleness, or Energia (as the Greeks call it) of the writer. But let this be a sufficient, though short note, that we miss the right use of the materia] point of Poesy.

Now, for the outside of it, which is words, or (as I may term it) Diction ${ }^{36}$, it is even well worse.

36 Readers of Lyly and his imitators (who include 
So is that honey-flowing Matron Eloquence apparelled, or rather disguised, in a Courtesanlike painted affectation : one time with so far-set words, they may seem Monsters : but must seem strangers to any poor English man : another time, with coursing of a Letter, as if they were bound to follow the method of a Dictionary: another time, with figures and flowers, extremely winterstarved. But I would this fault were only peculiar to Versifiers, and had not as large possession among Prose-printers; and (which is to be marvelled) among many Scholars ; and (which is to be pitied) among some Preachers. Truly I could wish, if at least I might be so bold to wish in a thing beyond the reach of my capacity, the diligent imitators of Tully and Demosthenes (most worthy to be imitated) did not so much keep Nizolian Paper-

Shakespeare in some early plays) need not be reminded that the works of prose-style selected for censure in these paragraphs belong to the literary movement known as Euphuism. The best contribution of the Euphuists to English prose is their sentence-building and paragraphconstruction, which introduced the ideas of law and order into the wearisome and interminable periods in which older writers were wont to lose their drift. But Lyly, whose style of composition in Euphues was based primarily on the Spanish example of Guevara's Dial of Princes and secondarily on the Latin works of Cicero and Seneca, committed all the faults which Sidney stigmatizes here. The 'far-set' or far-fetched words ; the 'coursing of a letter' or 'letter-hunting', which was the appropriate description of alliteration affected to excess : the similes laboriously introduced from Pliny and other natural historians (" all herbalists, all stories of beasts ... are rifled up ') - these are all early and familiar characteristics of the movement known as Euphuism, to which our modulated prose, through Addison, Burke, and Macaulay, owes so much of its dignity and ornateness. 
books ${ }^{37}$ of their figures and phrases, as by attentive translation (as it were) devour them whole, and make them wholly theirs. For now they cast Sugar and Spice upon every dish that is served to the table; like those Indians, not content to wear ear-rings at the fit and natural place of the ears, but they will thrust Jewels through their nose and lips because they will be sure to be fine.

Tully, when he was to drive out Catiline, as it were with a Thunder-bolt of eloquence, often used that figure of repetition, Vivit vivit? imo Senatum venit etc. Indeed, inflamed with a well-grounded rage, he would have his words (as it were) double out of his mouth : and so do that artificially which we see men do in choler naturally. And we, having noted the grace of those words, hale them in sometime to a familiar Epistle, when it were to too much choler to be choleric. Now for similitudes, in certain printed discourses, I think all Herbalists, all stories of Beasts, Fowls, and Fishes, are rifled up, that they come in multitudes, to wait upon any of our conceits; which certainly is as absurd a surfeit to the ears as is possible : for the force of a similitude not being to prove anything to a contrary Disputer, but only to explain to a willing hearer, when that is done, the rest is a most tedious prattling: rather over-swaying the memory from the purpose whereto they were applied than any whit informing the judgment, already either satisfied, or by similitudes not to be

37 Marius Nizolius, an Italian grammarian of the I6th century Renaissance, was the compiler of a Thesaurus Ciceronianus, and gave his name to commonplace books of quotable or notable passages. 
satisfied. For my part, I do not doubt, when Antonius and Crassus, the great forefathers of Cicero in eloquence, the one (as Cicero testifieth of them) pretended not to know Art, the other not to set by it : because, with a plain sensibleness, they might win credit of popular ears; which credit is the nearest step to persuasion: which persuasion is the chief mark of Oratory ; I do not doubt (I say) but that they used these tracks very sparingly, which who doth generally use, any many may see doth dance to his own music: and so be noted by the audience, more careful to speak curiously than to speak truly.

Undoubtedly (at least to my opinion undoubtedly), I have found in divers smally learned Courtiers a more sound style than in some professors of learning : of which I can guess no other cause, but that the Courtier following that which by practice he findeth fittest to nature, therein (though he know it not) doth according to Art, though not by Art : where the other, using Art to show Art, and not to hide Art (as in these cases he should do) flyeth from nature, and indeed abuseth Art ${ }^{38}$.

But what ? : methinks I deserve to be pounded, for straying from Poetry to Oratory: but both have such an affinity in this wordish consideration that I think this digression will make my meaning receive the fuller understanding: which is not to take upon me to teach Poets how they should do, but only finding myself sick among the rest, to show some one or two spots of the common infec-

38 Note the clearness and soundness of this application of the principle of æsthetics, ars est celare artem. 
tion grown among the most part of writers : that acknowledging ourselves somewhat awry, we may bend to the right use both of matter and manner ; whereto our language giveth us great occasion, being indeed capable of any excellent exercising of it. I know some will say it is a mingled language. And why not so much the better, taking the best of both the other? Another will say it wanteth Grammar. Nay truly, it hath that praise, that it wanteth not Grammar : for Grammar it might have, but it needs it not; being so easy of itself, and so void of those cumbersome differences of Cases, Genders, Moods and Tenses, which I think was a piece of the Tower of Babilon's ${ }^{39}$ curse, that a man should be put to school to learn his mother-tongue. But for the uttering sweetly and properly the conceits of the mind, which is the end of speech, that hath it equally with any other tongue in the world : and is particularly happy in compositions of two or three words together ${ }^{40}$, near the Greek, far beyond the Latin: which is one of the greatest beauties can be in a language.

Now, of versifying there are two sorts, the one Ancient, the other Modern : the Ancient marked the quantity of each syllable, and, according to that, framed his verse : the Modern, observing only number (with some regard of the accent), the chief life of it standeth in that like sounding of the words which we call Rhyme. Whether of these be the most excellent would bear many speeches. The

39 Babilon, i.e. Babel.

40 That is, compound words. 
Ancient (no doubt) more fit for Music, both words and tune observing quantity, and more fit lively to express divers passions, by the low and lofty Sound of the well-weighed syllable. The latter likewise, with its Rhyme, striketh a certain music to the ear : and in fine, since it doth delight, though by another way, it obtains the same purpose : there being in either sweetness, and wanting in neither majesty. Truly the English, before any other vulgar language I know, is fit for both sorts : for, for the Ancient, the Italian is so full of Vowels, that it must ever be cumbered with Elisions. The Dutch, so of the other side with Consonants, that they cannot yield the sweet sliding, fit for a Verse. The French, in his whole language, hath not one word that hath its accent in the last syllable saving two, called Antepenultima, and little more hath the Spanish: and therefore, very gracelessly may they use Dactyls. The English is subject to none of these defects.

Now for the rhyme, though we do not observe quantity, yet we observe the accent very precisely : which other languages either cannot do, or will not do so absolutely. That Cæsura, or breathing-place in the midst of the verse, neither Italian nor Spanish have, the French, and we, never almost fail of. Lastly, even the very rhyme itself, the Italian cannot put in the last syllable, by the French named the Masculine rhyme, but still in the next to the last, which the French call the Female; or the next before that, which the Italians term Sdrucciola. The example of the former is Buono, Suono, of the Sdrucciola, Femina, Semina. The French, of the other side, hatb 
both the Male, as Bon, Son, and the Female, as Plaise, Taise. But the Sdrucciola he hath not: where the English hath all three, as Due, True, Father, Rather, Motion, Potion ${ }^{41}$; with much more which might be said, but that I find already the triflingness of this discourse is much too much enlarged. So that since the ever-praise-worthy Poesy is full of virtue-breeding delightfulness, and void of no gift that ought to be in the noble name of learning: since the blames laid against it are either false, or feeble : since the cause why it is not esteemed in England is the fault of Poet-apes, not Poets: since lastly, our tongue is most fit to honour Poesy, and to be honoured by Poesy, I conjure you all that have had the evil luck to read this ink-wasting toy of mine, even in the name of the nine Muses, no more to scorn the sacred mysteries of Poesy : no more to laugh at the name of Poets, as though they were next inheritors to Fools : no more to jest at the reverent title of a Rhymer : but to believe with Aristotle that they were the ancient Treasurers of the Grecians' Divinity. To believe with Bembus that they were first bringers in of all civility. To believe with Scaliger that no Philosopher's precepts can sooner make you an honest man than the reading of Virgil. To believe with Clauserus, the Translator of Cornutus, that it pleased the heavenly Deity, by Hesiod and Homer, under the veil of fables, to give us all knowledge, Logic, Rhetoric, Philosophy, natural and moral ; and Quid non? To believe with me, that there are many mysteries

41 The -ion words were trisyllabic, as frequently in Shakespeare. 
contained in Poetry which of purpose were written darkly, lest by profane wits it should be abused. To believe with Landin that they are so beloved of the Gods that whatsoever they write, proceeds of a divine fury. Lastly, to believe themselves, when they tell you they will make you immortal by their verses.

Thus doing, your name shall flourish in the Printers' shops ; thus doing, you shall be of kin to many a poetical Preface; thus doing, you shall be most fair, most rich, most wise, most all, you shall dwell upon Superlatives. Thus doing, though you be Libertino patre natus, you shall suddenly grow Hercules proles:

\section{Si quid mea carmina possunt.}

Thus doing, your soul shall be placed with Dante's Beatrix, or Virgil's Anchises. But if (fie of such a but!) you be borne so near the dull-making Cataract of Nilus, that you cannot hear the Planet-like Music of Poetry, if you have so earthcreeping a mind that it cannot lift itself up to look to the sky of Poetry: or rather, by a certain rustical disdain, will become such a Mome as to be a Momus of Poetry : then, though I will not wish unto you the Ass's ears of Midas, nor to be driven by a Poet's verses, (as Bubonax was) to hang himself, nor to be rhymed to death, as is said to be done in Ireland: yet thus much curse I must send you, in the behalf of all Poets, that while you live, you live in love, and never get favour, for lacking skill of a Sonnet: and when you die, your memory die from the earth, for want of an Epitaph. 



\section{GEORGE PUTTENHAM}

\section{INTRODUCTORY CHAPTER ${ }^{1}$ \\ OF LANGUAGE}

SPEECH is not natural to man saving for his only hability to speak, and that he is by kind apt to utter all his conceits with sounds and voices diversified many manner of ways, by means of the many and fit instruments he hath by nature to that purpose, as a broad and voluble tongue, thin and movable lips, teeth even and not shagged, thick ranged, a round vaulted palate, and a long throat, besides an excellent capacity of wit that maketh him more disciplinable and imitative than any other creature ${ }^{2}$. Then as to the form and

1 This chapter forms Ch. IV of Book III (' Of Ornament') in The Art of English Poesy. I have brought it up to this place and have entitled it "Introductory Chapter', because the writer's remarks on language seem appropriately to open his treatment 'of poets and poesy'. It was with this chapter in mind that Prof. Arber described Puttenham as 'the Archbishop Trench of his age'.

2 Note how Puttenham in this exordium goes straight back to the physical conditions of speech. The English Board of Education, in their Suggestions for the Consideration of Teachers (Cd. 2638, 1905), similarly state that ' experience has shown that it is best to begin by calling attention to the sounds that are produced by the visible organs of speech'. 
action of his speech, it cometh to him by art and teaching, and by use or exercise.

But after a speech is fully fashioned to the common understanding, and accepted by consent of a whole country and nation, it is called a language, and receiveth none allowed alteration but by extraordinary occasions by little and little, as it were insensibly bringing in of many corruptions that creep along with the time ${ }^{3}$; of all which matters, we have more largely spoken in our books of the originals and pedigree of the English tongue ${ }^{4}$. Then when I say language, I mean the speech wherein the Poet or maker writeth, be it Greek or Latin, or as our case is the vulgar English, and when it is peculiar unto a country it is called the mother-speech of that people. The Greeks term it Idioma: so is ours at this day the NormanEnglish. Before the Conquest of the Normans it was the Anglo-saxon, and before that the British, which as some will is at this day the Welsh, or as others affirm the Cornish: I for my part think neither of both, as they be now spoken and pronounced.

This part in our maker or Poet must be heedily looked unto, that it be natural, pure, and the most

3 Cf. Trencl, On the Study of Words, V, (Routledge), and Bradley, The Making of English, Chs. III and IV, (Macmillan).

4 This work on 'the originals and pedigree of the English tongue' is not extant, nor have we any trace of other books by the author of the present treatise to which he refers, such as Hierotechni, De Decoro, comedies, interludes, and hymns. The literary activity of the writer of The Art of English Poesy makes the difficulty of identifying him more remarkable. 
usual of all his country : and for the same purpose rather that which is spoken in the king's Court, or in the good towns and cities within the land, than in the marches and frontiers, or in porttowns, where strangers haunt for traffic's sake, or yet in Universities where scholars use much peevish affectation of words out of the primitive languages ${ }^{5}$, or finally, in any uplandish village or corner of a Realm, where is no resort but of poor rustical or uncivil people. Neither shall he follow the speech of a craftsman or carter, or other of the inferior sort, though he be inhabitant or bred in the best town and city in this Realm, for such persons do abuse good speeches by strange accents or ill-shapen sounds, and false orthography. But he shall follow generally the better brought up sort, such as the Greeks call charientes, men civil and graciously behavoured and bred.

Our maker therefore at these days shall not follow Piers Plowman nor Gower nor Lydgate nor yet Chaucer, for their language is now out of use with us; neither shall he take the terms of Northern-men, such as they use in daily talk, whether they be noble men or gentlemen, or of their best clerks all is a matter; nor in effect any speech used beyond the river of Trent, though no man can deny but that theirs is the purer English Saxon at this day, yet it is not so Courtly nor so current as our Southern English is, no more is the far Western man's speech. Ye shall therefore take

${ }^{5}$ Puttenham was probably thinking of the Cambridge clique, 'The Areopagus', headed by Gabriel Harvey (1545-1630), the tone of which was certainly donnish and indeed not seldom 'peevish'. 
the usual speech of the Court, and that of London and the shires lying about London within sixty miles, and not much above ${ }^{6}$.

I say not this but that in every shire of England there be gentlemen and others that speak but specially write as good Southern as we of Middlesex or Surrey do, but not the common people of every shire, to whom the gentlemen and also their learned clerks do for the most part condescend, but herein we are already ruled by the English Dictionaries and other books written by learned men, and therefore it needeth none other direction in that behalf. Albeit peradventure some small admonition be not impertinent, for we find in our English writers many words and speeches amendable, and ye shall see in some many inkhorn terms so ill affected brought in by men of learning as preachers and schoolmasters : and many strange terms of other languages by Secretaries and Merchants and travellers, and many dark words and not usual nor well-sounding, though they be daily spoken in Court. Wherefore great heed must be taken by our maker in this point that his choice be good.

6 The literary geography of this paragraph is particularly valuable. The sixty-mile radius has social importance, derived from the conditions of Elizabethan England, and reference may here be made to the Memoirs of Robert Cary, Earl of Monmouth, who was Warden of the Marches during the last ten years of the Queen's reign ('King's Classics,' Moring). It need hardly be added that the literary value, e.g., of Tennyson's dialect-poems, or of the ' Kailyard' novelists, or of the Barrack Room Ballads, or of the East London school of fiction, is founded on the continuance of Puttenham's principle, though extended beyond his home-counties. 
And peradventure the writer hereof be in that behalf no less faulty than any other, using many strange and unaccustomed words and borrowed from other languages; and in that respect himself no meet Magistrate to reform the same errors in any other person. But since he is not unwilling to acknowledge his own fault, and can the better tell how to amend it, he may seem a more excusable corrector of other men's: he intendeth therefore for an indifferent way and universal benefit to tax himself first and before any others.

These be words used by the author in this present treatise : (i.) scientific, but with some reason, for it answereth the word mechanical, which no other word could have done so properly, for when he spake of all artificers which rest either in science or in handy-craft, it followed necessarily that scientific should be coupled with mechanical, or else neither of both to have been allowed, but in their places ; a man of science liberal and a handicraftsman, which had not been so cleanly a speech as the other. (ii.) Major-domo : in truth this word is borrowed of the Spaniard and Italian, and therefore new and not usual, but to them that are acquainted with the affairs of Court; and so for his jolly magnificence (as this case is) may be accepted among Courtiers, for whom this is specially written. A man might have said instead of Major-domo the French word (maistre d'hostell) but illfavouredly, or the right English word (Lord Steward.) But methinks for my own opinion this word Major-domo, though it be borrowed, is more acceptable than any of the rest ; other men may judge otherwise.

(iii.) Politician,

E.L.

H 
this word also is received from the Frenchmen, but at this day usual in Court and with all good Secretaries, and cannot find an English word to match it, for to have said a man politique had not been so well : because in truth that had been no more than to have said a civil person. Politician is rather a surveyor of civility than civil, and a public minister or Counsellor in the state. Ye have also this word (iv.) Conduct, a French word, but well allowed of us, and long since usual ; it sounds somewhat more than this word (leading) for it is applied only to the leading of a Captain, and not as a little boy should lead a blind man, therefore more proper to the case when he said conduct of whole armies ${ }^{7}$. Ye find also this word (v.) Idiom, taken from the Greeks, yet serving aptly when a man wanteth to express so much unless it be in two words, which surplusage to avoid we are allowed to draw in other words single, and as much significative. This word (vi.) significative is borrowed of the Latin and French, but to us brought in first by some Noble-man's Secretary, as I think, yet doth so well serve the turn as it could not now be spared. And many more like usurped Latin and French words: as, Method, methodical, placation, function, assubtiling, refining, compendious, prolix, figurative, inveigle. A term borrowed of our common Lawyers, impression, also a new term, but well expressing the matter, and more than our English word. These words, Numerous, numerosity, metrical, harmonical, but they cannot be refused, specially in this place for

7 On synonymous, or, rather, alternative words, see Trench, $o p$. cit., VI, 'On the Distinction of Words'. 
description of the art. Also ye find these words, penetrate, penetrable, indignity, which I cannot see how we may spare them, whatsoever fault we find with Ink-horn terms : for our speech wanteth words to such sense so well to be used. Yet instead of indignity ye have unworthiness ; and for penetrate we may say pierce, and that a French term also, or broach or enter into with violence, but not so well sounding as penetrate. Item, savage, for wild : obscure, for dark. Item, these words, declination, delineation, dimension, are scholastical terms indeed, and yet very proper.

But peradventure (and I could bring a reason for it) many other like words borrowed out of the Latin and French were not so well to be allowed by us as these words, audacious, for bold : facundity, for eloquence : egregious, for great or notable : implete, for replenished : attemptat, for attempt : compatible, for agreeable in nature, and many more. But herein the noble Poet Horace hath said enough to satisfy us all in these few verses :

Multa renascentur qux iam cecidere cadentque Quæ nunc sunt in honore vocabula si volet usus Quem penes arbitrium est et vis et norma loquendi. ${ }^{8}$

Which I have thus englished, but nothing with so good grace, nor so briefly as the Poet wrote :

Many a word yfal'n shall eft arise And such as now been held in highest prise Will fall as fast, when use and custom will Only umpires of speech, for force and skill. 


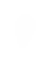




\section{OF POETS AND POESY}

\section{CHAPTER I}

WHAT A POET AND POESY IS, AND WHO MAY BE WORTHILY SAID THE MOST EXCELLENT POET OF OUR TIME.

A POET is as much to say as a maker. And our English name well conforms with the Greek word :

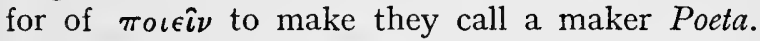
Such as (by way of resemblance and reverently) we may say of God who, without any travail to his divine imagination, made all the world of nought, nor also by any pattern or mould as the Platonics with their Ideas do phantastically suppose. Even so the very Poet makes and contrives out of his own brain both the verse and matter of his poem, and not by any foreign copy or example, as doth the translator, who therefore may well be said a versifier, but not a Poet.

The premises ${ }^{1}$ considered, it giveth to the name and profession no small dignity and preeminence above all other artificers, scientific ${ }^{2}$ or

1 The 'premises' are conventional. Sidney and Webbe start with the same reference to the Greek ' maker'.

2 For the writer's defence of this term, and of others used in these early chapters, see p. II 3 supra. 
mechanical. And nevertheless, without any repugnancy at all, a Poet may in some sort be said a follower or imitator, because he can express the true and lively of everything which is set before him, and which he taketh in hand to describe : and so in that respect is both a maker and a counterfeiter : and Poesy an art not only of making, but also of imitation. And this science in its perfection cannot grow but by some divine instinct: the Platonics call it furor; or by excellence of nature and complexion; or by great subtlety of the spirits and wit; or by much experience and observation of the world, and course of kind, or peradventure by all or most part of them. Otherwise how was it possible that Homer, being but a poor private man, and, as some say, in his later age blind, should so exactly set forth and describe, as if he had been a most excellent Captain or General, the order and array of battles, the conduct of whole armies, the sieges and assaults of cities and towns?; or, as some great Prince's major-domo and perfect Surveyor in Court, the order, sumptuousness and magnificence of royal banquets, feasts, weddings, and interviews?; or, as a Politician very prudent and much inured with the private and public affairs, so gravely examine the laws and ordinances civil, or so profoundly discourse in matters of estate and forms of all politic regiment ? Finally, how could he so naturally point out the speeches, countenance and manners of princely persons and private, to wit, the wrath of Achilles, the magnanimity of Agamemnon, the prudence of Menelaus, the prowess of Hector, the majesty 
of king Priamus, the gravity of Nestor, the policies and eloquence of Ulysses, the calamities of the distressed Queens, and valiance of all the Captains and adventurous knights in those lamentable wars of Troy?

It is therefore of Poets thus to be conceived, that if they be able to devise and make all these things of themselves, without any subject of verity, that they be (by manner of speech) as creating gods. If they do it by instinct divine or natural then surely much favoured from above. If by their experience, then no doubt very wise men. If by any precedent or pattern laid before them, then truly the most excellent imitators and counterfeitors of all others.

But you, Madame ${ }^{3}$ my most Honoured and Gracious, if I should seem to offer you this my device for a discipline and not a delight, I might well be reputed, of all others the most arrogant and injurious; yourself being already, of any that I know in our time, the most excellent Poet. Forsooth, by your Princely purse, favours, and countenance, making in manner what ye list, the poor man rich, the lewd ${ }^{4}$ well-learned, the

3 Puttenham was writing for Queen Elizabeth, and the popular style of his treatise is mainly due to the fact that it was addressed to the instruction of ladies. The excessive adulation of the Queen as a poet, which occurs here and in Chapter XXXI below, is a sin of the times not in the least affecting the value of the rest of the criticism.

4 Lewd=ignorant (from lay=not clerical); see Trench op. cit, p. 9, and ct. (among countless other examples) Chaucer, Canterbury Tales:

For if a preest be foul, on whom we truste, No wonder is a lewed man to ruste.

Prologue, 501-2. 
coward courageous, and vile both noble and valiant. Then for imitation no less, your person as a most cunning counterfeiter lively representing Venus in countenance, in life Diana, Pallas for government, and Juno in all honour and regal magnificence.

\section{CHAPTER II}

THAT THERE MAY BE AN ART OF OUR ENGLISH POESY,

AS WELL AS THERE IS OF THE LATIN AND GREEK.

Then as there was no art in the world till by experience found out, so if Poesy be now an Art, and of all antiquity hath been among the Greeks and Latins, and yet were none, until by studious persons fashioned and reduced into a method of rules and precepts, then no doubt may there be the like with us. And if the art of Poesy be but a skill appertaining to utterance, why may not the same be with us as well as with them, our language being no less copious, pithy, and significant than theirs, our conceits the same, and our wits no less apt to devise and imitate than theirs were? If again Art be but a certain order of rules prescribed by reason and gathered by experience, why should not Poesy be a vulgar Art with us as well as with the Greeks and Latins, our language admitting no fewer rules and nice diversities than theirs, but peradventure more, by a peculiar which our speech hath in many things differing from theirs?, and yet, in the general points of 
that Art, allowed to go in common with them : so that, if one point perchance is their feet, whereupon their measures stand, and which indeed is all the beauty of their Poesy, and which feet we have not, nor as yet never went about to frame (the nature of our language and words not permitting it), we have instead thereof twenty other curious points in that skill more than they ever had, by reason of our rhyme and tunable concords or symphony, which they never observed.

Poesy therefore may be an Art in our vulgar, and that very methodical and commendable.

\section{CHAPTER III}

HOW POETS WERE THE FIRST PRIESTS, THE FIRST PROPHETS, THE FIRST LEGISLATORS AND POLITICIANS IN THE WORLD.

THE profession and use of Poesy is most ancient from the beginning, and not, as many erroneously suppose, after but before any civil society was among men. For it is written that Poesy was the original cause and occasion of their first assemblies, when before the people remained in the woods and mountains, vagrant and dispersed like the wild beasts, lawless and naked, or very ill-clad, and of all good and necessary provision for harbour or sustenance utterly unfurnished, so as they little differed for their manner of life from the very brute beasts of the field.

Whereupon it is feigned that Amphion and 
Orpheus, two Poets of the first ages, one of them, to wit Amphion, builded up cities, and reared walls with the stones that came in heaps to the sound of his harp, figuring thereby the mollifying of hard and stony hearts by his sweet and eloquent persuasion. And Orpheus assembled the wild beasts to come in herds to hearken to his music, and by that means made them tame, implying thereby, how by his discreet and wholesome lessons, uttered in harmony and with melodious instruments, he brought the rude and savage people to a more civil and orderly life, nothing, as it seemeth, more prevailing or fit to redress and edify the cruel and sturdy courage of man than it. And as these two Poets and Linus before them, and Musæus also and Hesiod in Greece and Arcadia so by all likelihood had more Poets done in other places, and in other ages before them, though there be no remembrance left of them, by reason of the records by some accident of time perished and failing.

Poets therefore are of great antiquity ${ }^{5}$. Then forasmuch as they were the first that intended

5 There is considerable learning in this chapter and the next, and evidence of wide reading, though the conclusions are stated in a popular form. The rise of sententious poetry followed very closely the lines indicated here, but the poet-function was secondary to the priest-function, and the rude rhythm of the oracles was merely a mnemonic convenience. "How Poets were the first Priests, etc., in the world' is a misleading chapter-heading, which begs the question of the antiquity of poetry as such. It should rather read 'How Priests, etc., were the earliest Poets'. But Puttenham's special plea is sufficiently accurate for his purpose, which was to vindicate the dignity of poetry. 
to the observation of nature and her works, and specially of the celestial courses, by reason of the continual motion of the heavens, searching after the first mover, and from thence by degrees coming to know and consider of the substances separate and abstract, which we call the divine intelligences or good Angels (Demons), they were the first that instituted sacrifices of placation, with invocations and worship to them, as to Gods ; and invented and established all the rest of the observances and ceremonies of religion, and so were the first Priests and ministers of the holy mysteries.

And because for the better execution of that high charge and function it behoved them to live chaste and in all holiness of life, and in continual study and contemplation, they came by instinct divine and by deep meditation and much abstinence (the same assubtiling and refining their spirits) to be made apt to receive visions, both waking and sleeping, which made them utter prophecies, and foretell things to come. So also were they the first Prophets or seers, Videntes, for so the Scripture termeth them in Latin after the Hebrew word, and all the oracles and answers of the gods were given in metre or verse, and published to the people by their direction. And for that they were aged and grave men, and of much wisdom and experience in the affairs of the world, they were the first lawmakers to the people, and the first politicians, devising all expedient means for the establishment of commonwealth, to hold and contain the people in order and duty by force and virtue of good and wholesome laws, 
made for the preservation of the public peace and tranquillity. The same peradventure not purposely intended, but greatly furthered by the awe of their gods, and such scruple of conscience as the terrors of their late invented religion had led them into.

\section{CHAPTER IV}

HOW POETS WERE THE FIRST PHILOSOPHERS, THE FIRST ASTRONOMERS AND HISTORIOGRAPHERS AND ORATORS AND MUSICIANS OF THE WORLD.

UTTERANCE also and language is given by nature to man for persuasion of others, and aid of themselves-I mean the first ability to speak. For speech itself is artificial and made by man, and the more pleasing it is the more it prevaileth to such purpose as it is intended for. But speech by metre is a kind of utterance more cleanly couched and more delicate to the ear than prose is, because it is more current and slipper upon the tongue, and withal tunable and melodious, as a kind of Music, and therefore may be termed a musical speech or utterance, which cannot but please the hearer very well. Another cause is-that it is briefer and more compendious and easier to bear away and be retained in memory than that which is contained in multitude of words and full of tedious ambage and long periods. It is beside a manner of utterance more cloquent and rhetorical than the ordinary prose which we use in our daily 
talk : because it is decked and set out with all manner of fresh colours and figures, which maketh that it sooner inveigleth the judgment of man, and carrieth his opinion this way and that, whithersoever the heart by impression of the ear shall be most affectionately bent and directed.

The utterance in prose is not of so great efficacy because not only it is daily used, and by that occasion the ear is overglutted with it, but is also not so voluble and slipper upon the tongue, being wide and loose, and nothing numerous, nor contrived into measures, and sounded with so gallant and harmonical accents, nor in fine allowed that figurative conveyance, nor so great licence in choice of words and phrases as metre is. So that the Poets were also from the beginning the best persuaders and their eloquence the first Rhetoric of the world.

Even so it became that the high mysteries of the gods should be revealed and taught by a manner of utterance and language of extraordinary phrase, and brief and compendious, and above all others sweet and civil as the metrical is. The same also was meetest to register the lives and noble jests of Princes, and of the great Monarchs of the world, and all other the memorable accidents of time: so that the Poet was also the first historiographer ${ }^{6}$.

6 Puttenham should have drawn his instance from ballad-poetry. The Hom eric poems are doubtless founded on the ballads brought from camp to camp by minstrels. It must be recollected that P uttenham's object is popular in scope : he is interested in asserting the importance of poetry, rather than in discovering or discussing its scientific origins. 
Then, forasmuch as they were the first observers of all natural causes and effects in the things generable and corruptible, and from thence mounted up to search after the celestial courses and influences, and yet penetrated further to know the divine essences and substances separate, as is said before, they were the first Astronomers and Philosophists and Metaphysics.

Finally, because they did altogether endeavour themselves to reduce the life of man to a certain method of good manners, and made the first differences between virtue and vice, and then tempered all these knowledges and skills with the exercise of a delectable Music by melodious instruments, which withal served them to delight their hearers, and to call the people together by admiration to a plausible and virtuous conversation, therefore were they the first Philosophers Ethic and the first artificial Musicians of the world. Such was Linus, Orpheus, Amphion and Musæus the most ancient Poets and Philosophers, of whom there is left any memory by the profane writers. King David also and Solomon, his son, and many other of the holy Prophets wrote in metres, and used to sing them to the harp, although to many of us ignorant of the Hebrew language and phrase and not observing it, the same seem but a prose. It cannot be therefore that any scorn or indignity should justly be offered to so noble, profitable, ancient and divine a science as Poetry is. 


\section{CHAPTER V}

HOW THE WILD AND SAVAGE PEOPLE USED A NATURAL POESY IN VERSICLE AND RHYME AS OUR VULGAR IS.

AND the Greek and Latin Poesy was by verse numerous and metrical, running upon pleasant feet, sometimes swift, sometimes slow (their words very aptly serving that purpose), but without any rhyme or tunable concord in the end of their verses, as we and all other nations now use. But the Hebrews and Chaldees, who were more ancient than the Greeks, did not only use a metrical Poesy but also with the same a manner of rhyme, as hath been of late observed by learned men. Whereby it appeareth that our vulgar running Poesy was common to all the nations of the world besides whom the Latins and Greeks in special called barbarous. So that it was notwithstanding the first and most ancient Poesy and the most universal, which two points do otherwise give to all humane inventions and affairs no small credit.

This is proved by certificate of merchants and travellers, who by late navigations have surveyed the whole world and discovered large countries and strange peoples wild and savage, affirming that the American, the Perusine, and the very Cannibal, do sing and also say their highest and holiest matters in certain rhyming versicles and not in prose, which proves also that our manner of vulgar Poesy is more ancient than the artificial 
of the Greeks and Latins, ours coming by instinct of nature, which was before Art or observation, and used with the savage and uncivil, who were before all science or civility, even as the naked by priority of time is before the clothed, and the ignorant before the learned. The natural Poesy therefore, being aided and amended by Art, and not utterly altered or obscured, but some sign left of it (as the Greeks and Latins have left none), is no less to be allowed and commended than theirs ${ }^{7}$.

7 The argument in this chapter is not convincing. If rhyme is merely a savage device for mnemonic convenience in the absence of writing, comparable to the convenience of nakedness versus clothes, the defence of rhyme falls to the ground. Superior antiquity is not necessarily superior art. As a fact, Marlowe in this age was the first to realize and display the capabilities of unrhymed verse in dramatic composition, and the use of rhyme has since been gradually restricted in English practice to the less exalted forms of poetry, epic and dramatic poems (with certain variants of epos, such as Tennyson's Idylls of the King) being composed in blank verse. The decay of rhyme as an ornament to narrative poetry can be traced from the pointed distichs of Pope in the eighteenth century through the broken paragraphs of music, still composed in rhymed couplets, of Keats at the beginning of the nineteenth, to the blank verse of Wordsworth and Tennyson. In certain kinds of gorgeous narration, such as William Morris's Earthly Paradise, an elaborate scheme of rhyme adds-as in Spenser's Faerie Queen-to the decorative effect. Shakespeare's disuse of rhyme is an interesting chapter in the psychology of poetry, and Milton, of course, disdained so meretricious. an aid to musical expression.

'Vulgar' above= current, usual. 


\section{CHAPTER VI}

HOW THE RHYMING POESY CAME FIRST TO THE GRECIANS AND LATINS, AND HAD ALTERED AND ALMOST SPOILT THEIR MANNER OF POESY.

But it came to pass, when fortune fled far from the Greeks and Latins, and that their towns flourished no more in traffic, nor their Universities in learning as they had done continuing those Monarchies, the barbarous conquerors invading them with innumerable swarms of strange nations, the Poesy metrical of the Grecians and Latins came to be much corrupted and altered, insomuch that there were times that the very Greeks and Latins themselves took pleasure in rhyming verses, and used it as a rare and gallant thing. Yea, their Orators profess the Doctors' Sermons were acceptable neither to Princes nor yet to the common people unless it went in manner of tunable rhyme or metrical sentences, as appears by many of the ancient writers, about that time and since. And the great Princes, and Popes, and Sultans would salute and greet one another sometimes in friendship and sport, sometimes in earnest and enmity by rhyming verses, and nothing seemed clerkly done but must be done in rhyme; whereof we find divers examples from the time of the Emperors Gracian and Valentinian downwards. For thenabouts began the declin. ation of the Roman Empire, by the notable inundations of the Huns and Vandals in Europe,

E.L. 
under the conduct of Totila and Attila and other their generals.

This brought the rhyming Poesy in grace, and made it prevail in Italy and Greece (their own long time cast aside, and almost neglected), till after many years the peace of Italy and of the Empire Occidental revived new clerks, who recovering and perusing the books and studies of the civiller ages, restored all manner of arts, and that of the Greek and Latin Poesy withal, into their former purity and neatness. Which nevertheless did not so prevail, but that the rhyming Poesy of the Barbarians remained still in its reputation, that one in the school, this other in Courts of Princes more ordinary and allowable.

\section{CHAPTER VII}

HOW IN THE TIME OF CHARLEMAGNE AND MANY YEARS AFTER HIM THE LATIN POETS WROTE IN RHYME.

AND this appeareth evidently by the works of many learned men, who wrote about the time of Charlemagne's reign in the Empire Occidental, where the Christian Religion became through the excessive authority of Popes and deep devotion of Princes strongly fortified and established by erection of orders Monastical, in which many simple clerks for devotion sake and sanctity were received more than for any learning, by which 
occasion and the solitariness of their life waxing studious without discipline or instruction by any good method, some of them grew to be historiographers, some Poets, and following either the barbarous rudeness of the time, or else their own idle inventions, all that they wrote to the favour or praise of Princes, they did it in such manner of minstrelsy, and thought themselves no small fools, when they.could make their verses go all in rhyme as did the school of Salerne, dedicating their book of medicinal rules unto our king of England, with this beginning :

Anglorum Rege scripsit tota schola Salerni

$\mathrm{Si}$ vis incolumem, si vis te reddere sanum

Curas tolle graves, irasci crede prophanum

Nec retine ventrem nec stringas fortiter anum.

And all the rest that follow throughout the whole book more curiously than cleanly, nevertheless very well to the purpose of their art.

In the same time King Edward III, himself quartering the Arms of England and France, did discover his pretence and claim to the Crown of France in these rhyming verses:

Rex sum regnorum bina ratione duorum Anglorum regno sum rex ego iure paterno Matris iure quidem Francorum nuncupor idem Hinc est armorum variatio facta meorum.

Which verses Philip de Valois then possessing the Crown as next heir male by pretext of the law Salique, and holding out Edward the Third, answered in these other of as good stuff : 
Prædo regnorum qui diceris esse duorum

Regno materno privaberis atque paterno

Prolis ius nullum ubi matris non fuit ullum

Hinc est armorum variatio stulta tuorum.

It is found written of Pope Lucius for his great avarice and tyranny used over the Clergy thus in rhyming verses :

Lucius est piscis rex et tyrannus aquarum

A quo discordat Lucius iste parum

Devorat hic homines, his piscibus insidiatur

Esurit hic semper hic aliquando satur

Amborum vitam silaus æquata notaret

Plus rationis habet qui ratione caret.

And as this was used in the greatest and gayest matters of Princes and Popes by the idle invention of Monastical men then reigning all in their superlative, so did every scholar and secular clerk or versifier, when he wrote any short poem or matter of good lesson, put it in rhyme, whereby it came to pass that all your old Proverbs and common sayings, which they would have plausible to the reader and easy to remember and bear away, were of that sort as these:

In mundo mira faciunt duo nummus et ira

Mollificant dura pervertunt omnia iura.

And this verse in dispraise of the Courtier's life following the Court of Rome :

Vita palatina dura est animæque ruina.

And these written by a noble learned man:

Ire redire sequi regum sublimia castra

Eximius status est, sed non sic itur ad astra. 
And this other which to the great injury of all women was written (no doubt by some forlorn lover, or else some old malicious Monk) for one woman's sake blemishing the whole sex:

Fallere flere nere mentiri nilque tacere Hæc quinque vere statuit Deus in muliere.

If I might have been his Judge, I would have had him for his labour served as Orpheus was by the women of Thrace. His eyes to be picked out with pins for his so deadly belying of them, or worse handled if worse could be devised. But will ye see how God raised a revenger for the silly innocent women, for about the same rhyming age came an honest civil Courtier somewhat bookish, and wrote these verses against the whole rabble of Monks :

O Monachi vestri stomachi sunt amphora Bacchi Vos estis Deus est testis turpissima pestis.

Anon after came your secular Priests as jolly rhymers as the rest, who being sore aggrieved with their Pope Calixtus, for that he had enjoined them from their wives, and railed as fast against him :

$O$ bone Calixte totus mundus perodit te Quondam Presbiteri, poterant uxoribus uti Hoc destruxisti, postquam tu Papa fuisti.

Thus, what in writing of rhymes and registering of lies, was the Clergy of that fabulous age wholly occupied.

We find some but very few of these rhyming verses among the Latins of the civiller ages, and those rather happening by chance than of any 
purpose in the writer, as this Distich among the disports of Ovid :

Quot cœlum stellas tot habet tua Roma puellas

Pascua quotque hædos tot habet tua Roma Cynædos.

The posterity taking pleasure in this manner of symphony had leisure as it seems to devise many other knacks in their versifying that the ancient and civil Poets had not used before, whereof one was to make every word of a verse to begin with the same letter, as did Hugobald the Monk who made a large poem to the honour of Carolus Calvus, every word beginning with $\mathrm{C}$, which was the first letter of the king's name, thus :

Carmina clarisonæ Calvis cantate camenæ.

And this was thought no small piece of cunning, being indeed a matter of some difficulty to find out so many words beginning with one letter as might make a just volume, though in truth it were but a phantastical device and to no purpose at all more than to make them harmonical to the rude ears of those barbarous ages.

Another of their pretty inventions was to make a verse of such words as by their nature and manner of construction and situation might be turned backward word by word, and make another perfect verse, but of quite contrary sense, as the gibing Monk that wrote of Pope Alexander these two verses:

Laus tua non tua fraus, virtus non copia rerum, scanllere te faciunt hoc decus eximium. 
Which if ye will turn backwards they make two other good verses, but of a contrary sense, thus :

Eximium decus hoc faciunt te scandere, rerum Copia, non virtus, fraus tua non tua laus.

\section{And they called it Verse Lyon.}

Thus you may see the humours and appetites of men, how divers and changeable they be in liking new fashions, though many times worse than the old, and not only in the manner of their life and use of their garments, but also in their learnings and arts and specially of their languages ${ }^{8}$.

\section{CHAPTER VIII}

IN WHAT REPUTATION POESY AND POETS WERE IN OLD TIME WITH PRINCES AND OTHERWISE GENERALLY, AND HOW THEY BE NOW BECOME CONTEMPTIBLE AND FOR WHAT CAUSES.

For the respects aforesaid in all former ages and in the most civil countries and commonwealths good Poets and Poesy were highly esteemed and much favoured of the greatest Princes. For proof whereof we read how much Amyntas, King of Macedonia, made of the Tragical Poet Euripides. And the Athenians of Sophocles. In what price

8 The conclusion is more valuable than the examples, though it is interesting to note Puttenham's contempt for the monks so shortly after the suppression of the Monasteries by Henry VIII (I539) 
the noble poems of Homer were holden with Alexander the great, insomuch that every night they were laid under his pillow, and by day were carried in the rich jewel coffer of Darius lately before vanquished by him in battle. And not only Homer, the father and Prince of the Poets, was so honoured by him, but for his sake all other meaner Poets, insomuch that Cherillus, one no very great good Poet, had for every verse well made a Philip's noble of gold, amounting in value to an angel English, and so for every hundred verses (which a cleanly pen could speedily dispatch) he had a hundred angels.

And since Alexander the Great how Theocritus, the Greek poet was favoured by Ptolemy King of Egypt and Queen Berenice his wife, Ennius likewise by Scipio, Prince of the Romans, Virgil also by the Emperor Augustus. And in later times how much were Jehan de Mehune and Guillaume de Loris made of by the French kings, and Geoffrey Chaucer, father of our English poets, by Richard the Second, who as it was supposed gave him the manor of new Holme in Oxfordshire. And Gower to Henry the Fourth, and Harding to Edward the Fourth. Also how Francis, the French king, made Sangelais, Salmonius, Macrinus, and Clement Marot of his privy Chamber for their excellent skill in vulgar and Latin Poesy. And King Henry VIII, her Majesty's father, for a few Psalms of David turned into English metre by Sternhold, made him groom of his privy chamber, and gave him many other good gifts. And one Gray, what good estimation did he grow unto with the same King Henry and afterward with the 
Duke of Somerset, Protector, for making certain merry Ballads, whereof one chiefly was 'The hunt is up, the hunt is up'. And Queen Mary, his daughter, for one Epithalamy or nuptial song made by Vargas, a Spanish Poet, at her marriage with King Philip in Winchester, gave him during his life two hundred crowns pension: nor this reputation was given them in ancient times altogether in respect that Poesy was a delicate art, and the Poets themselves cunning Princepleasers, but for that also they were thought for their universal knowledge to be very sufficient men for the greatest charges in their commonwealth were it for counsel or for conduct, whereby no man need to doubt but that both skills may very well concur and be most excellent in one person.

For we find that Julius Cæsar, the first Emperor and a most noble captain, was not only the most eloquent Orator of his time but also a very good Poet, though none of his doings therein be now extant. And Quintus Catullus, a good Poet, and Cornelius Gallus, treasurer of Egypt, and Horace, the most delicate of all the Roman Lyrics, was thought meet and by many letters of great instance provoked to be Secretary of State to Augustus the Emperor, which nevertheless he refused for his unhealthfulness' sake, and being a quiet minded man and nothing ambitious of glory : non voluit accedere ad Rempublicam, as it is reported. And Ennius, the Latin Poet, was not, as some perchance think, only favoured by Scipio the African for his good making of verses, but used as his familiar and counsellor in the wars for his great knowledge and amiable conversation. And long 
before that Antimenides and other Greek Poets, as Aristotle reports in his Politics, had charge in the wars. And Tyrtæus the Poet, being also a lame man and halting upon one leg, was chosen by the Oracle of the gods from the Athenians to be general of the Lacedæmonians' army, not for his Poetry, but for his wisdom and grave persuasions and subtle stratagems, whereby he had the victory over his enemies. So that the Poets seemed to have skill not only in the subtleties of their art but also to be meet for all manner of functions civil and martial, even as they found favour of the times they lived in, insomuch as their credit and estimation generally was not small.

But in these days (although some learned Princes may take delight in them) yet universally it is not so. For as well Poets as Poesy are despised, and the name become, of honourable infamous, subject to scorn and derision, and rather a reproach than a praise to any that useth it ${ }^{2}$. For commonly whoso is studious in the Art, or shows himself excellent in it, they call him in disdain a phantastical, and a light-headed or phantastical man (by conversion) they call a Poet. And this proceeds through the barbarous ignorance of the time, and pride of many Gentlemen and others whose gross heads not being brought up or acquainted with any excellent Art, nor able to contrive or ir manner conceive any matter of subtlety in any business or science, they do deride and scorn it in all others as superfluous knowledges

9 This recurring note of apology is once more to be traced to the influences which are represented by Gosson's School of Abuse. 
and vain sciences, and what soever device be of rare invention they term it phantastical, construing it to the worst side. And among men such as be modest and grave, and of little conversation, nor delighted in the busy life and vain ridiculous actions of the popular, they call him in scorn a Philosopher or Poet, as much to say as a phantastical man, very injuriously (God wot) and to the manifestation of their own ignorance, not making difference betwixt terms.

For as the evil and vicious disposition of the brain hinders the sound judgment and discourse of man with busy and disordered phantasies, for

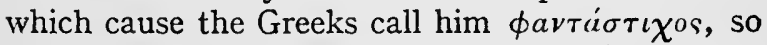
is that part being well affected not only nothing disorderly or confused with any monstrous imaginations or conceits, but very formal, and in its much multiformity uniform, that is well-proportioned and so passing clear that by it as by a glass or mirror are represented unto the soul all manner of beautiful visions, whereby the inventive part of the mind is so much holpen, as without it no man could devise any new or rare thing. And where it is not excellent in its kind, there could be no politic captain, nor any witty engineer o1 cunning artificer, nor yet any law-maker or counsellor of deep discourse. Yea, the Prince of Philosophers sticks not to say animam non in. telligere absque phantasmate, which text to anothe1 purpose Alexander Aphrodiscus well noteth, as learned men know.

And this phantasy may be resembled to a glass, as hath been said, whereof there be many tempers and manner of makings, as the per- 
spectives do acknowledge. For some be false glasses and show things otherwise than they be indeed, and others right as they be indeed, neither fairer nor fouler, nor greater nor smaller. There be again of these glasses that show things exceeding fair and comely, others that show figures very monstrous and illfavoured. Even so is the phantastical part of man (if it be not disordered) a representer of the best, most comely and beautiful images or appearances of things to the soul and according to their very truth. If otherwise, then doth it breed chimaras and monsters in man's imaginations, and not only in his imaginations, but also in all his ordinary actions and life which ensues. Wherefore such persons as be illuminated with the brightest irradiations of knowledge and of the verity and due proportion of things, they are called by the learned men not phantastici but euphantasiote, and of this sort of phantasy are all good Poets, notable captains stratagematic, all cunning artificers and engineers, all Legislators, Politicians and Counsellors of estate, in whose exercises the inventive part is most employed and is to the sound and true judgment of man most needful ${ }^{10}$.

This diversity in the terms perchance every man hath not noted, and thus much be said in defence of the Poet's honour, to the end no noble and generous mind be discomforted in the study thereof, the rather for that worthy and honourable

10 Puttenham is groping in the foregoing remarks towards a description of the faculty which now is called imagination. 
memorial of that noble woman twice French Queen, Lady Anne of Britain, wife first to King Charles VIII, and after to Lewis XII, who passing one day from her lodging toward the king's side, saw in a gallery Master Allan Chartier the king's secretary, an excellent maker or Poet leaning on a table's end asleep, and stooped down to kiss him, saying thus in all their hearings : "We may not of Princely courtesy pass by and not honour with our kiss the mouth from whence so many sweet ditties and golden poems have issued'. But methinks at these words I hear some smilingly say, I would be loth to lack living of my own till the Prince gave me a manner of new Elm ${ }^{11}$ for my rhyming. And another to say, I have read that the Lady Cynthia came once down out of her sky to kiss the fair young lad Endymion as he lay asleep; and many noble Queens that have bestowed kisses upon their Princes' paramours, but never upon any Poets. The third, methinks, shruggingly saith, I kept not to sit sleeping with my Poesy till a Queen came and kissed me. But what of all this? Princes may give a good Poet such convenient countenance and also benefit as are due to an excellent artificer, though they neither kiss nor coax them, and the discreet Poet looks for no such extraordinary favours, and as well doth he honour by his pen the just, liberal or magnanimous Prince, as the valiant, amiable or beautiful, though they be every one of them the good gifts of God.

So it seems not altogether the scorn and ordinary disgrace offered unto Poets at these days is cause why few Gentlemen do delight in the Art, but for

$11 \mathrm{Elm}=$ elmess $=$ alms. 
that liberality is come to fail in Princes, who for their largess were wont to be accounted the only patrons of learning and first founders of all excellent artificers. Besides it is not perceived, that Princes themselves do take any pleasure in this science, by whose example the subject is commonly led and allured to all delights and exercises, be they good or bad, according to the grave saying of the historian: Rex multitudinem religione implevit, qua semper regenti similis est. And peradventure, in this iron and malicious age of ours, Princes are less delighted in it, being over earnestly bent and affected to the affairs of Empire and ambition, whereby they are as it were enforced to endeavour themselves to arms and practices of hostility, or to intend to the right policing of their states, and have not one hour to bestow upon any other civil or delectable Art of natural or moral doctrine, nor scarce any leisure to think one good thought in perfect and godly contemplation, whereby their troubled minds might be moderated and brought to tranquillity ${ }^{12}$. So that it is hard to find in these days of noblemen or gentlemen any good Mathematician, or excellent Musician, or notable Philosopher, or else a cunning Poet, because we find few great Princes much delighted in the same

12 The argument in this paragraph has amari aliquid, a touch of bitterness. Where so little is known of the author of this treatise, it is admissible to conjecture that he had had rebuffs in high places. Promotion under Elizabeth depended almost entirely on 'the favour of Princes' (cp. Shakespeare's Henry VIII, Bacon's Essays, Memoirs of Robert Cary, Earl of Monmouth, etc.), and every career was open to talent, so that ithis iron and malicious age of ours' has a personal sound. 
studies. Now also of such among the Nobility or gentry as be very well seen in many laudable sciences and especially in making of Poesy it is so come to pass that they have no courage to write, and if they have, yet are they loth to be a-known of their skill. So that I know very many notable Gentlemen in the Court that have written commendably and suppressed it again, or else suffered it to be published without their own names to it : as if it were a discredit for a Gentleman to seem learned, and to show himself amorous of any good Art.

In other ages it was not so, for we read that Kings and Princes have written great volumes and published them under their own regal titles. As, to begin with, Solomon the wisest of Kings, Julius Caesar the greatest of Emperors, Hermes Trismegistus the holiest of Priests and Prophets; Evax, king of Arabia, wrote a book of precious stones in verse; Prince Avicenna, of Physic and Philosophy ; Alphonsus, King of Spain, his astronomical Tables; Almansor, a king of Morocco, diverse Philosophical works, and by their regal example our late sovereign Lord King Henry the Eighth wrote a book in defence of his faith ${ }^{\mathbf{1 3}}$, then persuaded that it was the true and Apostolical doctrine, though it hath appeared otherwise since, yet his honour and learned zeal was nothing less to be allowed. Queens also have been known studious and to write large volumes, as Lady Margaret of France, Queen of Navarre in our

13 Henry VIII's book was the Assertio septem Sacramentorum, written against Luther in 1521 , twelve years before his excommunication by the Pope. He also wrote a preface to the Institution of a Christian Man. 
time 14. But of all others the Emperor Nero was so well learned in Music and Poesy that, when he was taken by order of the Senate and appointed to die, he offered violence to himself and said, $O$ quantus artifex pereo!, as much as to say : How is it possible a man of such science and learning as myself should come to this shameful death ? The Emperor Octavian being made executor to Virgil, who had left by his last will and testament, that his books of the Eneid should be committed to the fire as things not perfected by him, made his excuse for infringing the dead's will by a number of verses most excellently written, whereof these are part :

Frangatur potius legum veneranda potestas, Quam tot congestos noctesque diesque labores Hauserit una dies

and put his name to them. And before him his uncle and father-adoptive Julius Caesar was not ashamed to publish under his own name his Commentaries of the French and Britannic wars.

Since therefore so many noble Emperors, Kings and Princes have been studious of Poesy and other civil arts, and not ashamed to bewray their skills in the same, let none other meaner person despise learning, nor (whether it be in prose or in Poesy, if they themselves be able to write, or have written anything well or of rare invention) be any whit squeamish to let it be published under their

14 The Heptameron, I 558. The other examples of royal authorship industriously collected by Puttenham need not detain us; we may add the names of King Charles I (Eikon Basilike) and Queen Victoria to the list. 
names, for reason serves it and modesty doth not repugn.

\section{CHAPTER IX}

HOW POESY SHOULD NOT BE EMPLOYED UPON VAIN CONCEITS, OR VICIOUS, OR INFAMOUS.

WHEREFORE, the nobility and dignity of the Art considered, as well by universality as antiquity and the natural excellence of itself, Poesy ought not to be abased and employed upon any unworthy matter and subject, nor used to vain purposes, which nevertheless is daily seen, and that is to utter conceits infamous and vicious or ridiculous and foolish, or of no good example and doctrine. Albeit in merry matters (not unhonest) being used for man's solace and recreation it may be well allowed, for as I said before, Poesy is a pleasant manner of utterance, varying from the ordinary of purpose to refresh the mind by the ears' delight.

Poesy also is not only laudable because I said it was a metrical speech used by the first men, but because it is a metrical speech corrected and reformed by discreet judgments and with no less cunning and curiosity than the Greek and Latin Poesy, and by Art beautified and adorned and brought far from the primitive rudeness of the first inventors; otherwise it may be said to me that Adam and Eve's aprons were the gayest garments because they were the first, and the shepherd's tent or pavilion the best housing because it was the most ancient and most universal.

E.I. 
Which I would not have so taken, for it is not my meaning ; but that Art and cunning, concurring with nature, antiquity and universality, in things indifferent, and not evil, do make them more laudable ${ }^{15}$. And right so our vulgar rhyming Poesy, being by good wits brought to that perfection, we see is worthily to be preferred before any other manner of utterance in prose, for such use and to such purpose as it is ordained and shall hereafter be set down more particularly.

\section{CHAPTER $\mathrm{X}$}

THE SUBJECT OR MATTER OF POESY

HAving sufficiently said of the dignity of Poets and Poesy, now it is time to speak of the matter or subject of Poesy, which to mine intent is whatsoever witty ${ }^{16}$ and delicate conceit of man meet

15 This modifies the views expressed by Puttenham in $\mathrm{Ch}$. $\mathrm{V}$ above; see note in loc.

${ }_{16}$ The Elizabethan meaning of 'witty' differs somewhat from the modern sense. 'Wit ', briefly, was equivalent to what we call 'culture' to-day. This culture, however, was more or less an artificial product; at least it was imported raw. In other words the ' wits' of the Court had no prose language of culture. They had to introduce it from abroad, modelling their cultivated style for speech and writing on the 'alto estilo' of Guevara's Dial of Princes, translated by Sir Thomas North in 1557, and on other arbiters of culture, who themselves went back to ancient Roman types of sentence-building. The cult of culture was driven to excess, and mannerisms of writing were exaggerated in the forms of antitheses, alliteration (known as 'letter-hunting'), and so forth. Lyly's Euphues (subtitled The Anatomy of Wit=the analysis of culture) gave the impetus to the movement in England.

' Conceit' $=$ conception. 
or worthy to be put in written verse, for any necessary use of the present time, or good instruction of the posterity.

But the chief and principal is : the laud, honour and glory of the immortal gods (I speak now in phrase of the Gentiles). Secondly, the worthy gests of noble Princes : the memorial and registry of all great fortunes, the praise of virtue and reproof of vice, the instruction of moral doctrines, the revealing of sciences natural and other profitable Arts, the redress of boisterous and sturdy courages by persuasion, the consolation and repose of temperate minds, finally the common solace of mankind in all his travails and cares of this transitory life. And in this last sort, being used for recreation only, may allowably bear matter not always of the gravest or of any great commodity or profit, but rather, in some sort, vain, dissolute, or wanton, so it be not very scandalous and of evil example.

But as our intent is to make this Art vulgar for all Englishmen's use, and therefore is of necessity to set down the principal rules therein to be observed, so in mine opinion it is no less expedient to touch briefly all the chief points of this ancient Poesy of the Greeks and Latins, so far forth as it conformeth with ours. So as it may be known what we hold of them as borrowed and what as of our own peculiar. Wherefore now that we have said what is the matter of Poesy, we will declare the manner and forms of poems used by the ancients. 


\section{CHAPTER XI}

OF POEMS AND THEIR SUNDRY FORMS AND HOW THEREBY THE ANCIENT POETS RECEIVED SURNAMES.

As the matter of Poesy is diverse so was the form of their poems and manner of writing, for all of them wrote not in one sort, even as all of them wrote not upon one matter. Neither was every Poet alike cunning in all as in some one kind of Poesy, nor uttered with like felicity. But wherein any one most excelled, thereof he took a surname ${ }^{17}$, as to be called a Poet Heroic, Lyric, Elegiac, Epigrammatist, or otherwise.

Such therefore as gave themselves to write long histories of the noble gests of kings and great princes intermeddling the dealings of the gods, half-gods or heroes of the gentiles, and the great and weighty consequences of peace and war, they called Poets Heroic, whereof Homer was chief and most ancient among the Greeks, Virgil among the Latins. Others who more delighted to write songs or ballads of pleasure, to be sung with the voice and to the harp, lute, or citheron and such other musical instruments, they were called melodious Poets, or by a more common name Lyric Poets, of which sort was Pindar, Anacreon and Callimachus with others among the Greeks, Horace and Catullus among the Latins. There were another sort who sought the favour of fair Ladies, and coveted to bemoan their estates at

17 The 'surname' is, of course, a descriptive epithet limiting the extension of 'poet' to !the particular kind of poetry affected. 
large and the perplexities of love in a certain piteous verse called Elegy, and thence were called Elegiac: such among the Latins were Ovid, Tibullus, and Propertius.

There were also Poets that wrote only for the stage, I mean plays and interludes, to recreate the people with matters of disport, and to that intent did set forth in shows, pageants accompanied with speech, the common behaviours and manner of life of private persons, and such as were the meaner sort of men, and they were called Comical Poets, of whom among the Greeks Menander and Aristophanes were most excellent, with the Latins Terence and Plautus. Besides those Poets Comic there were other who served also the stage, but meddled not with so base matters. For they set forth the doleful falls of unfortunate and afflicted Princes, and were called Poets Tragical. Such were Euripides and Sophocles with the Greeks, Seneca among the Latins.

There were yet others who mounted nothing so high as any of them both, but in base and humble style by manner of Dialogue uttered the private and familiar talk of the meanest sort of men, as shepherds, haywards ${ }^{18}$ and such like: such was among the Greeks Theocritus, and Virgil among the Latins; their poems were named Eclogues or shepherdly talk.

There was yet another kind of Poet, who intended to tax the common abuses and vice of the people in rough and bitter speeches, and their invectives were called Satires, and themselves

18 Hayward = warder of the common: one of his duties was to prevent cattle from breaking the hedge (=hay). 
Satirics. Such were Lucilius, Juvenal and Persius among the Latins, and with us he that wrote the book called Piers plowman. Others of a more fine and pleasant head were given wholly to taunting and scoffing at indecent things, and in short poems uttered pretty merry conceits, and these men were called Epigrammatists. There were others that for the people's good instruction and trial of their own wits used in places of great assembly to say by rote numbers of short and sententious metres, very pithy and of good edification, and thereupon were called Poets Mimists : as who would say, imitable and meet to be followed for their wise and grave lessons.

There was another kind of poem, invented only to make sport and to refresh the company with a manner of buffoonery or counterfeiting of merry speeches, converting all that which they had heard spoken before to a certain derision by a quite contrary sense, and this was done when Comedies or Tragedies were a-playing, and that between the acts, when the players went to make ready for another, there was great silence, and the people waxed weary, then came in these manner of counterfeit vices; they were called Pantomimi, and all that had before been said, or great part of it, they gave a cross construction to it very ridiculously. Thus have you how the names of the Poets were given them by the forms of their poems and manner of writing. 


\section{CHAPTER XII}

IN WHAT FORM OF POESY THE GODS OF THE GENTILES WERE PRAISED AND HONOURED.

THE gods of the Gentiles were honoured by their Poets in hymns, which is an extraordinary and divine praise, extolling and magnifying them for their great powers and excellency of nature in the highest degree of laud, and yet therein their Poets were after a sort restrained, so that they could not with their credit untruly praise their own gods, or use in their lauds any manner of gross adulation or unveritable report. For in any writer untruth and flattery are counted most great reproaches. Wherefore to praise the gods of the Gentiles, for that by authority of their own fabulous records they had fathers and mothers and kindred and allies and wives and concubines, the Poets first commended them by their genealogies or pedigrees, their marriages and alliances, their notable exploits in the world for the behoof of mankind, and yet as I said before, none otherwise than the truth of their own memorials might bear, and in such sort as it might be well avouched by their old written reports, though in very deed they were not from the beginning all historically true, and many of them very fictions, and such of them as were true were grounded upon some part of an history or matter of verity, the rest altogether figurative and mystical, covertly applied to some moral or natural sense, as Cicero setteth it forth in his books De Natura Deorum. 
For to say that Jupiter was son to Saturn, and that he married his own sister Juno, might be true, for such was the guise of all great Princes in the Oriental part of the world both at those days and now is. Again, that he loved Danae, Europa, Leda, Calisto and other fair Ladies, daughters to kings, besides many meaner women, it is likely enough, because he was reported to be a very incontinent person; but that he should be the highest god in heaven, or that he should thunder and lighten, and do many other things very unnaturally and absurdly; it seemeth to be some witty device and fiction made for a purpose, or a very noble and impudent lie, which could not be reasonably suspected by the Poets, who were otherwise discreet and grave men, and teachers of wisdom to others. Therefore either to transgress the rules of their primitive records, or to seek to give their gods honour by belying them (otherwise than in that sense which I have alleged), had been a sign not only of an unskilful Poet but also of a very impudent and lewd man. For untrue praise never giveth any true reputation.

But with us Christians, who be better disciplined, and do acknowledge but one God Almighty, everlasting, and in every respect self-sufficient, reposed in all perfect rest and sovereign bliss, not needing or exacting any foreign help or good, to him we cannot exhibit overmuch praise, nor belie him any ways, unless it be in abasing his excellency by scarcity of praise, or by misconceiving his divine nature, weening to praise him, if we impute to him such vain delights and peevish affections as commonly the frailest men are reproved for 
Namely to make him ambitious of honour, jealous and difficult in his worships, terrible, angry, vindictive, a lover, a hater, a pitier, and indigent of man's worships: finally, so passionate as in effect he should be altogether Anthropopathic ${ }^{19}$. To the gods of the Gentiles they might well attribute these infirmities, for they were but the children of men, great Princes and famous in the world, and not for any other respect divine than by some resemblance of virtue they had to do good and to benefit many. So, as to the God of the Christians such divine praise might be verified, to the other gods none, but figuratively or in mystical sense, as hath been said. In which sort the ancient Poets did indeed give them great honours and praises, and made to them sacrifices, and offered them oblations of sundry sorts, even as the people were taught and persuaded by such placations and worships to receive any help, comfort or benefit to themselves, their wives, children, possessions or goods.

For if that opinion were not, who would acknowledge any God?, the very etymology of the name with us of the North parts of the world declaring plainly the nature of the attribute, which is all one as if we said good, or a giver of good things. Therefore the Gentiles prayed for peace to the goddess Pallas; for war (such as thrived by it) to the god Mars; for honour and empire to the god Jupiter; for riches and wealth to Pluto: for eloquence and gain to Mercury ; for safe navigation

19 Anthropopathic $=$ of like passions or feelings as men ; the common description of this attribute is anthropomorphic, meaning, literally, of the same form as men. 
to Neptune ; for fair weather and prosperous winds to Eolus; for skill in music and leechcraft to Apollo ; for free life and chastity to Diana ; for beauty and good grace, as also for issue and prosperity in love, to Venus; for plenty of crop and corn to Ceres; for seasonable vintage to Bacchus; and for other things to others. So many things as they could imagine good and desirable, and to so many gods as they supposed to be authors thereof, in so much as Fortune was made a goddess, and the fever quartain had her altars, such blindness and ignorance reigned in the hearts of men at that time, and whereof it first proceeded and grew, besides the opinion hath been given, appeareth more at large in our books of Hierotechni ${ }^{20}$, the matter being of another consideration than to be treated of in this work.

And these hymns to the gods was the first form of Poesy and the highest and the stateliest, and they were sung by the Poets as priests, and by the people or whole congregation as we sing in our Churches the Psalms of David. But they did it commonly in some shady groves of tall timber trees, in which places they reared altars of green turf, and bestrewed them all over with flowers, and upon them offered their oblations and made their bloody sacrifices (for no kind of gift can be dearer than life) of such quick cattle as every god was in their conceit most delighted in or in some other respect most fit for the mystery. Temples or churches or other chapels than these they had none at those days.

20 The book has not survived otherwise than in this reference ; it shows the archæological bent of Puttenham's mind. 


\section{CHAPTER XIII}

IN WHAT FORM OF POESY VICE AND THE COMMON ABUSES OF MAN'S LIFE WAS REPREHENDED.

SOME perchance would think that next after the praise and honouring of their gods should commence the worshippings and praise of good men, and specially of great Princes and governors of the earth in sovereignty and function next unto the gods. But it is not so, for before that came to pass the Poets or holy Priests chiefly studied the rebuke of vice, and to carp at the common abuses, such as were most offensive to the public and private, for as yet for lack of good civility and wholesome doctrines there was greater store of lewd lourdains than of wise and learned Lords or of noble and virtuous Princes and governors. So that, next after the honours exhibited to their gods, the Poets, finding in man generally much to reprove and little to praise, made certain poems in plain metres, more like to sermons or preachings than otherwise, and when the people were assembled together in those hallowed places dedicate to their gods, because they had yet no large halls or places of conventicle, nor had any other correction of their faults, but such as rested only in rebukes of wise and grave men, such as at these days make the people ashamed rather than afeared, the said ancient Poets used for that purpose, three kinds of poems reprehensive, to wit: the Satire, the Comedy, and the Tragedy.

The first and most bitter invective against vice and vicious men was the Satire, which, to the 
intent their bitterness should breed none ill will, either to the Poets or to the reciters (which could not have been chosen if they had been openly known), and besides to make their admonitions and reproofs seem graver and of more efficacy, they made wise as if the gods of the woods, whom they called Satyres or Silvans, should appear and recite those verses of rebuke, whereas indeed they were but disguised persons under the shape of Satyrs, as who would say, these terrene and base gods being conversant with man's affairs, and spiers out of all their secret faults, had some great care over man and desired by good admonitions to reform the evil of their life, and to bring the bad to amendment by those kind of preachings, whereupon the Poets, inventors of the devise, were called Satirists ${ }^{21}$.

\section{CHAPTER XIV}

HOW VICE WAS AFTERWARD REPROVED BY TWO OTHER MANNER OF POEMS, BETTER REFORMED THAN THE SATIRE, WHEREOF THE FIRST WAS COMEDY, THE SECOND TRAGEDY.

But when these manner of solitary speeches and recitals of rebuke, uttered by the rural gods out of bushes and briars, seemed not to the finer heads

21 The Roman satire was connected with the satura lanx, or full dish, in the sense of a 'pot-pourri '. Puttenham's critical historizing in these chapters is more popular than exact. 
sufficiently persuasive, nor so popular as if it were reduced into action of many persons, or by many voices lively represented to the ear and eye, so that a man might think it were even now a-doing, the Poets devised to have many parts played at once by two or three or four persons that debated the matters of the world; sometimes of their own private affairs, sometimes of their neighbours', but never meddling with any Prince's matters nor such high personages, but commonly of merchants, soldiers, artificers, good honest householders, and also of unthrifty youths, young damsels, old nurses, bawds, brokers, ruffians and parasites, with such like, in whose behaviours, lieth in effect the whole course and trade of man's life, and therefore tended altogether to the good amendment of man by discipline and example. It was also much for the solace and recreation of the common people by reason of the pageants and shows.

And this kind of poem was called Comedy, and followed next after the Satire, and by that occasion was somewhat sharp and bitter after the nature of the Satire, openly and by express names taxing men more maliciously and impudently than became, so that they were enforced for fear of quarrel and blame to disguise their players with strange apparel, and by colouring their faces and carrying hats and caps of divers fashions to make themselves less known. But as time and experience do reform every thing that is amiss, so this bitter poem called the old Comedy, being disused and taken away, the new Comedy came in place, more civil and pleasant a great deal, and not 
touching any man by name, but in a certain generality glancing at every abuse, so that from thenceforth fearing none ill-will or enmity at anybody's hands they lift aside their disguisings and played bare-face, till one Roscius Gallus ${ }^{22}$, the most excellent player among the Romans, brought up these vizards which we see at this day used, partly to supply the want of players, when there were more parts than there were persons, or that it was not thought meet to trouble and pester princes' chambers with too many folks. Now by the change of a vizard one man might play the king and the carter, the old nurse and the young damsel, the merchant and the soldier or any other part he listed very conveniently. There be that say Roscius did it for another purpose, for being himself the best Histrion or buffoon that was in his days to be found, insomuch as Cicero said Roscius contended with him by variety of lively gestures to surmount the copy of his speech, yet because he was squint-eyed and had a very unpleasant countenance, and looks which made him ridiculous or rather odious to the presence, he devised these vizards to hide his own ill-favoured face. And thus much touching the Comedy.

\section{CHAPTER XV}

IN WHAT FORM OF POESY THE EVIL AND OUTRAGEOUS BEHAVIOURS OF PRINCES WERE REPREHENDED.

But because in those days when the Poets first taxed by Satire and Comedy, there was no great

22 Quintus Roscius, the Roman actor, died about.62 B.c. 
store of Kings or Emperors or such high estates (all men being yet for the most part rude, and in a manner popularly equal) they could not say of them or of their behaviours anything to the purpose, which cases of Princes are sithens taken for the highest and greatest matters of all. But after that some men among the more became mighty and famous in the world, sovereignty and dominion having learned them all manner of lusts and licentiousness of life, by which occasions also their high estates and felicities fell many times into most low and lamentable fortunes; whereas before in their great prosperities they were both feared and reverenced in the highest degree, after their deaths when the posterity stood no more in dread of them, their infamous life and tyrannies were laid open to all the world, their wickedness reproached, their follies and extreme insolences derided, and their miserable ends painted out in plays and pageants, to show the mutability of fortune, and the just punishment of God in revenge of a vicious and evil life.

These matters were also handled by the Poets, and represented by action as that of the Comedies: but because the matter was higher than that of the Comedies the Poet's style was also higher and more lofty, the provision greater, the place more magnificent: for which purpose also the players' garments were made more rich and costly and solemn, and every other thing appertaining, according to that rate. So that, where the Satire was pronounced by rustical and naked Sylvans, speaking out of a bush, and the common players of interludes, called Plampedes, played 
barefoot upon the floor, the later Comedies upon scaffolds, and by men well and cleanly hosed and shod, these matters of great Princes were played upon lofty stages, and the actors thereof wore upon their legs buskins of leather, called Cothurni, and other solemn habits, and for a special pre-eminence did walk upon those high corked shoes or pantofles, which now they call in Spain and Italy Shoppini. And because those buskins and high shoes were commonly made of goats' skins very finely tanned and dyed into colours, or for that, as some say, the best player's reward was a goat to be given him, or for that, as others think, a goat was the peculiar sacrifice of the god Pan, king of all the gods of the woods, forasmuch as a goat in Greek is called Tragos, therefore these stately plays were called Tragedies.

And thus have ye four sundry forms of Poesy Dramatic reprehensive, and put in execution by the feat and dexterity of man's body, to wit: the Satire, old Comedy, new Comedy, and Tragedy, whereas all other kinds of poems except Eclogue, whereof shall be entreated hereafter, were only recited by mouth or sung with the voice to some melodious instrument.

\section{CHAPTER XVI}

IN WHAT FORM OF POESY THE GREAT PRINCES AND DOMINATORS OF THE WORLD WERE HONOURED.

Bur as tie bad and illaudable parts of all estates and degrees were taxed by the Poets in one sort 
or another, and those of great Princes by Tragedy in especial-and not till after their deaths, as hath been before remembered, to the intent that such exemplifying (as it were) of their blames and adversities, being now dead, might work for a secret reprehension to others that were alive, living in the same or like abuses-so was it great reason that all good and virtuous persons should for their well-doings be rewarded with commendation, and the great Princes above all others with honours and praises, being for many respects of greater moment to have them good and virtuous than any inferior sort of men. Wherefore the Poets being indeed the trumpeters of all praise and also of slander (not slander, but well deserved reproach) were in conscience and credit bound, next after the divine praises of the immortal gods, to yield a like ratable honour to all such amongst men as most resembled the gods by excellency of function, and had a certain affinity with them, by more than human and ordinary virtues shown in their actions here upon earth.

They were therefore praised by a second degree of laud : showing their high estates, their Princely genealogies and pedigrees, marriages, alliances, and such noble exploits as they had done in the affairs of peace and of war to the benefit of their people and countries, by invention of any noble science or profitable Art, or by making wholesome laws, or enlarging of their dominions by honourable and just conquests, and many other ways.

Such personages among the Gentiles were Bacchus, Ceres, Perseus, Hercules, Theseus and many other, who thereby came to be accounted E.L. 
gods and half-gods or goddesses, and had their commendations given by Hymn accordingly or by such other poems as their memory was thereby made famous to the posterity for ever after, as shall be more at large said in place convenient. But first we will speak somewhat of the playing places and provisions which were made for their pageants and pomps representative before remembered.

\section{CHAPTER XVII}

OF THE PLACES WHERE THEIR INTERLUDES OR POEMS DRAMATIC WERE REPRESENTED TO THE PEOPLE.

As it hath been declared, the Satires were first uttered in their hallowed places within the woods where they honoured their gods under the open heaven, because they had no other housing fit for great assemblies. The old comedies were played in the broad streets upon wagons or carts uncovered, which carts were floored with boards and made for removable stages to pass from one street of their towns to another, where all the people might stand at their ease to gaze upon the sights. Their new comedies or civil interludes were played in open pavilions or tents of linen-cloth or leather, half displayed, that the people might see.

Afterward, when Tragedies came up, they devised to present them upon scaffolds or stages of timber, shadowed with linen or leather as the 
other, and these stages were made in the form of a Semicircle, whereof the bow served for the beholders to sit in and the string or forepart was appointed for the floor or place where the players uttered, and had in it sundry little divisions by curtains as traverses to serve for several rooms where they might repair unto and change their garments and come in again, as their speeches and parts were to be renewed. Also there was place appointed for musicians to sing or to play upon their instruments at the end of every scene, to the intent the people might be refreshed, and kept occupied.

This manner of stage in half-circle the Greeks called theatrum, as much to say as a beholdingplace, which was also in such sort contrived by benches and greeces ${ }^{23}$ to stand or sit upon, as no man should impeach another's sight. But as civility and withal wealth increased so did the mind of man grow daily more haughty and superfluous in all his devices, so that for their theatres in half-circle they came to be by the great magnificence of the Roman princes and people sumptuously built with marble and square stone in form all round, and were called Amphitheatres, whereof as yet appears one among the ancient ruins of Rome, built by Pompeius Magnus, for capacity able to receive at ease fourscore thousand persons, as it is left written, and so curiously contrived as every man might depart at his pleasure, without any annoyance to other. It is also to be known that in those great Amphitheatres were exhibited

23 Greece, or grice (Latin, gressus)=a flight of steps. 
all manner of other shows and disports for the people, as their fence-plays, or digladiations of naked men, their wrestlings, runnings, leapings and other practices of activity and strength, also their baitings of wild beasts, as Elephants, Rhinoceros, Tigers, Leopards and others, which sights much delighted the common people, and therefore the places required to be large and of great content.

\section{CHAPTER XVIII}

OF THE SHEPHERDS' OR PASTORAL POESY CALLED ECLOGUE, AND TO WHAT PURPOSE IT WAS FIRST INVENTED AND USED.

Some be of opinion, and the chief of those who have written in this art among the Latins, that the pastoral Poesy which we commonly call by the name of Eclogue and Bucolic, a term brought in by the Sicilian Poets, should be the first of any other, and before the satire, comedy or tragedy, because, say they, the shepherds' and haywards' assemblies and meetings, when they kept their cattle and herds in the common fields and forests, was the first familiar conversation; and their babble and talk under bushes and shady trees the first disputation and contentious reasoning; and their fleshly heats, growing of ease, the first idle wooings; and their songs, made to their mates or paramours either upon sorrow or jollity of courage, the first amorous musics. Sometimes also they sang and played on their pipes for wagers, 
striving who should get the best game and be counted cunningest.

All this I do agree unto, for no doubt the shepherds' life was the first example of honest fellowship, their trade the first art of lawful acquisition or purchase, for at these days robbery was a manner of purchase. So saith Aristotle in his books of the Politics, and that pasturage was before tillage, or fishing, or fowling, or any other predatory art or chevisance. And all this may be true, for before there was a shepherd keeper of his own or of some other body's flock there was none owner in the world, quick cattle being the first property of any foreign possession. I say foreign because alway men claimed property in their apparel, and armour, and other like things made by their own travail and industry, nor thereby was there yet any good town or city or King's palace, where pageants and pomps might be shown by Comedies or Tragedies.

But for all this, I do deny that the Eclogue should be the first and most ancient form of artificial Poesy, being persuaded that the Poet devised the Eclogue long after the other dramatic poems, not of purpose to counterfeit or represent the rustical manner of loves and communication, but under the veil of homely persons and in rude speeches to insinuate and glance at greater matters, and such as perchance had not been safe to have been disclosed in any other sort, which may be perceived by the Eclogues of Virgil, in which are treated by figure matters of greater importance than the loves of Tityrus and Corydon. These Eclogues came after to contain and inform moral 
discipline, for the amendment of man's behaviour, as be those of Mantuan and other modern Poets.

\section{CHAPTER XIX}

OF HISTORICAL POESY, BY WHICH THE FAMOUS ACTS OF PRINCES AND THE VIRTUOUS AND WORTHY LIVES OF OUR FOREFATHERS WERE REPORTED.

THERE is nothing in man of all the potential parts of his mind (reason and will except) more noble or more necessary to the active life than memory : because it maketh most to a sound judgment and perfect worldly wisdom, examining and comparing the times past with the present, and, by them both considering the time to come, concludeth with a steadfast resolution what is the best course to be taken in all his actions and advices in this world. It came upon this reason experience to be so highly commended in all consultations of importance, and preferred before any learning or science, and yet experience is no more than a mass of memories assembled, that is, such trials as man hath made in time before. Right so no kind of argument in all the Oratory craft doth better persuade and more universally satisfy than example, which is but the representation of old memories, and like successes happened in times past.

For these regards the Poesy historical is of all other next the divine most honourable and worthy, as well for the common benefit as for the special 
comfort every man receiveth by it. No one thing in the world with more delectation reviving our spirits than to behold as it were in a glass the lively image of our dear forefathers, their noble and virtuous manner of life, with other things authentic, which because we are not able otherwise to attain to the knowledge of by any of our senses, we apprehend them by memory, whereas the present time and things so swiftly pass away that they give us no leisure aimost to look into them, and much less to know and consider of them thoroughly. The things future, being also events very uncertain, and such as cannot possibly be known because they be not yet, cannot be used for example nor for delight otherwise than by hope. Though many promise the contrary, by vain and deceitful arts taking upon them to reveal the truth of accidents to come, which if it were so as they surmise, are yet but sciences merely conjectural, and not of any benefit to man or to the common wealth, where they be used or professed.

Therefore the good and exemplary things and actions of the former ages, were reserved only to the historical reports of wise and grave men: those of the present time left to the fruition and judgment of our senses: the future as hazards and uncertain events utterly neglected and laid aside for Magicians and mockers to get their livings by: such manner of men as by negligence of Magistrates and remissness of laws every country breedeth great store of. These historical men nevertheless used not the matter so precisely to wish that all they wrote should be accounted true, for that was not needful nor expedient to the 
purpose, namely to be used either for example or for pleasure : considering that many times it is seen a feigned matter or altogether fabulous, besides that it maketh more mirth than any other, works no less good conclusions for example than the most true and veritable, but oftentimes more, because the Poet hath the handling of them to fashion at his pleasure, but not so of the other which must go according to their verity and none otherwise without the writer's great blame.

Again, as ye know, more and more excellent examples may be feigned in one day by a good wit than many ages through man's frailty are able to put in use, which made the learned and witty men of those times to devise many historical matters of no verity at all, but with purpose to do good and no hurt, as using them for a manner of discipline and precedent of commendable life. Such was the Commonwealth of Plato, and Sir Thomas More's Utopia, resting all in device, but never put in execution, and easier to be wished than to be performed.

And you shall perceive that histories were of three sorts, wholly true and wholly false, and a third holding part of either, but for honest recreation and good example they were all of them. And this may be apparent to us not only by the Poetical histories but also by those that be written in prose : for as Homer wrote a fabulous or mixed report of the siege of Troy, and another of Ulysses' errors or wanderings, so did Musæus compile a true treatise of the life and loves of Leander and Hero, both of them heroic, and to none ill edification. Also, as Thucydides wrote a worthy and 
veritable history of the wars betwixt the Athenians and the Peloponeses, so did Xenophon, a most grave Philosopher, and well trained courtier and counsellor, make another (but feigned and untrue) of the childhood of Cyrus king of Persia, nevertheless both to one effect, that is for example and good information of the posterity.

Now, because the actions of mean and base personages tend in very few cases to any great good example-for who passeth to follow the steps and manner of life of a craftsman, shepherd or sailor, though he were his father or dearest friend; yea, how almost is it possible that such manner of men should be of any virtue other than their profession requireth ?-therefore was nothing committed to history but matters of great and excellent persons and things, that the same by irritation of good courages (such as emulation causeth) might work more effectually, which occasioned the story-writer to choose a higher style fit for his subject-the Prosaic in prose, the Poet in metre-and the Poet's was by versehexameter for its gravity and stateliness most allowable ${ }^{24}$. Neither would they intermingle it

24 This passage is particularly interesting, the more so as there was at this time practically no English history. The contention that the "actions of mean and base personages' (in the social sense) 'tend in very few cases to any great good example', and the doubt expressed if 'such manner of mell should be of any virtue other than their profession requireth', are fallacies inherent in the age in which Puttenham was writing. The middleclass had only recently been added to the serious factors of social life, and the so-called lower-class (the 'masses', as distinguished by Gladstone from the 'classes ') were not definitely reckoned with till after the French Revolu- 
with any other shorter measure, unless it were in matters of such quality as became best to be sung with the voice, and to some musical instrument, as were with the Greeks all your Hymns and Encomia of Pindar and Callimachus, not very histories but a manner of historical reports, in which cases they made those poems in variable measures, and coupled a short verse with a long to serve that purpose the better. And we ourselves who compiled this treatise have written for pleasure a little brief Romance or historical ditty in the English tongue of the Isle of great Britain in short and long metres, and by breaches or divisions to be more commodiously sung to the harp in places of assembly, where the company shall be desirous to hear of old adventures and valiances of noble knights in times past, as are those of king Arthur and his knights of the round table, Sir Bevys of Southampton, Guy of Warwick and others like. Such as have not premonition hereof and consideration of the causes alleged would peradventure reprove and disgrace every Romance, or short historical ditty, for that they be not written in long metres or verses Alexandrines, according to the nature and style of large histories, wherein they should do wrong, for they be sundry forms of poems and not all one.

tion had democratized society. Greek and Roman society, being built on a foundation of slave-labour, it was inevitable that ancient history should take account of none but 'great and excellent persons and things'. Industrial and economic conditions were excluded, $e x$ hypothesi, from its survey. The relation of subject to form, as discussed below, is reasonably accurate. The ' author's historical ditty' has not survived. 


\section{CHAPTER XX}

IN WHAT FORM OF POESY VIRTUE IN THE INFERIOR SORT WAS COMMENDED.

IN every degree and sort of men virtue is commendable, but not equally: not only because men's estates are unequal, but for that also virtue itself is not in every respect of equal value and estimation. For continence in a king is of greater merit than in a carter, the one having all opportunities to allure him to lusts, and ability to serve his appetites, the other partly for the baseness of his estate wanting such means and occasions, partly by dread of laws more inhibited, and not so vehemently carried away with unbridled affections, and therefore deserve not in the one and the other like praise nor equal reward, by the very ordinary course of distributive justice.

Even so parsimony and illiberality are greater vices in a Prince than in a private person, and pusillanimity and injustice likewise: for to the one fortune hath supplied enough to maintain them in the contrary virtues-I mean fortitude, justice, liberality and magnanimity, the Prince having all plenty to use largess by, and no want or need to drive him to do wrong; also, all the aids that may be to lift up his courage and to make him stout and fearless; augent animos fortune, saith the Mimist, and very truly, for nothing pulleth down a man's heart so much as adversity and lack. Again, in a mean man, prodigality and pride are faults more reprehensible than in Princes, 
whose high estates do require in their countenance, speech and expense a certain extraordinary, and their functions enforce them sometimes to exceed the limits of mediocrity not excusable in a private person, whose manner of life and calling hath no such exigence. Besides the good and bad of Princes is more exemplary, and thereby of greater moment than the private persons'.

Therefore it is that the inferior persons with their inferior virtues have a certain inferior praise, to guerdon their good with, and to comfort them to continue a laudable course in the modest and honest life and behaviour. But this lieth not in written lauds so much as ordinary reward and commendation to be given them by the mouth of the superior magistrate. For histories were not intended to so general and base a purpose, albeit many a mean soldier and other obscure persons were spoken of and made famous in stories, as we find of Irus the beggar, and Thersites the glorious noddy, whom Homer maketh mention of. But that happened (and so did many like memories of mean men) by reason of some greater personage or matter that it was along of, which therefore could not be an universal case nor chance to every other good and virtuous person of the meaner sort. Wherefore the Poet, in praising the manner of life or death of any mean person, did it by some little ditty, or Epigram, or Epitaph, in few verses and mean style conformable to his subject.

So have you how the immortal gods were praised by hymns, the great Princes and heroic personages by ballads of praise called Encomia, both of them by historical reports of great gravity 
and majesty, the inferior persons by other slight poems.

\section{CHAPTER XXI}

THE FORM WHEREIN HONEST AND PROFITABLE ARTS AND SCIENCES WERE TREATED.

THE profitable sciences were no less meet to be imported to the greater number of civil men for instruction of the people and increase of knowledge than to be reserved and kept for clerks and great men only. So as next unto the things historical such doctrines and arts as the commonwealth fared the better by were esteemed and allowed. And the same were treated by Poets in verse-hexameter favouring the Heroical, and for the gravity and comeliness of the metre most used with the Greeks and Latins to sad purposes.

Such were the Philosophical works of Lucretius Carus among the Romans, the Astronomical of Aratus and Manilius, one Greek, the other Latin, the Medicinal of Nicander, and that of Oprianus of hunting and fishes, and many more that were too long to recite in this place.

\section{CHAPTER XXII}

IN WHAT FORM OF POESY THE AMOROUS AFFECTIONS AND ALLUREMENTS WERE UTTERED.

ThE first founder of all good affections is honest love, as the mother of all the vicious is hatred. 
It was not therefore without reason that so commendable, yea honourable, a thing as love well meant, were it in Princely estate or private, might in all civil commonwealths be uttered in good form and order as other laudable things are. And because love is of all other human affections the most puissant and passionate, and most general to all sorts and ages of men and women, so that whether it be of the young or old or wise or holy, or high estate or low, none ever could truly brag of any exemption in that case it requireth a form of Poesy variable, inconstant, affected, curious and most witty of any others, whereof the joys were to be uttered in one sort, the sorrows in another, and by the many forms of Poesy the many moods and pangs of lovers thoroughly to be discovered : the poor souls, sometimes praying, beseeching, sometimes honouring, advancing, praising ; another while railing, reviling, and cursing ; then sorrowing, weeping, lamenting; in the end laughing, rejoicing, and solacing the beloved again with a thousand delicate devices, odes, songs, elegies, ballads, sonnets and other ditties, moving one way and another to great compassion.

\section{CHAPTER XXIII}

THE FORM OF POETICAL REJOICINGS.

Pleasure is the chief part of man's felicity in this world, and also (as our Theologians say) in the world to come. Therefore while we may (yea, always, if it could be) to rejoice and take 
our pleasures in virtuous and honest sort, it is not only allowable, but also necessary and very natural to man. And many be the joys and consolations of the heart; but none greater than such as he may utter and discover by some convenient means; even as to suppress and hide a man's mirth, and not to have therein a partaker, or at least wise a witness, is no little grief and infelicity.

Therefore nature and civility have ordained (besides the private solaces) public rejoicings for the comfort and recreation of many. And they be of divers sorts and upon divers occasions grown. One and the chief was for the public peace of a country, the greatest of any other civil good, and wherein your Majesty (my most gracious Sovereign) have shown yourself to all the world for this one and thirty years' space of your glorious reign, above all other Princes of Christendom, not only fortunate but also most sufficient virtuous and worthy of Empire. Another is for just and honourable victory achieved against the foreign enemy. A third at solemn feasts and pomps of coronations and instalments of honourable orders. Another for jollity at weddings and marriages. Another at the births of Princes' children. Another for private entertainments in Court, or other secret disports in chamber, and such solitary places.

And as these rejoicings tend to divers effects, so do they also carry divers forms and nominations. For those of victory and peace are called Triumphal, whereof we ourselves have heretofore given some example by our Triumphals written in honour 
of her Majesty's long peace. And they were used by the ancients in like manner as we do our general processions or Litanies with banquets and bonfires and all manner of joys. Those that were to honour the persons of great Princes or to solemnize the pomps of any instalment were called Encomia, we may call them carols of honour. Those to celebrate marriages were called songs nuptial or Epithalamies, but in a certain mystical sense as shall be said hereafter. Others for magnificence at the nativities of Princes' children, or by custom used yearly upon the same days, are called songs natal or Genethliaca. Others for secret recreation and pastime in chambers with company or alone were the ordinary Musics amorous, such as might be sung with voice or to the Lute, Citheron, or Harp, or danced by measures as the Italian Pavan and galliard are at these days in Princes' Courts and other places of honourable or civil assembly, and of all these we will speak in order and very briefly.

\section{CHAPTER XXIV}

THE FORM OF POETICAL LAMENTATIONS.

LAMENTING is altogether contrary to rejoicing. Every man saith so, and yet is it a piece of joy to be able to lament with ease, and freely to pour forth a man's inward sorrows and the griefs wherewith his mind is surcharged.

This was a very necessary devise of the Poet and a fine-besides his poetry to play also the 
Physician, and not only by applying a medicine to the ordinary sickness of mankind, but by making the very grief itself (in part) cure of the disease. Now are the causes of man's sorrows many: the death of his parents, friends, allies, and children (though many of the barbarous nations do rejoice at their burials and sorrow at their births); the overthrows and discomforts in battle; the subversions of towns and cities; the desolations of countries; the loss of goods and worldly promotions, honour and good renown; finally, the travails and torments of love forlorn or ill-bestowed, either by disgrace, denial, delay, and twenty other ways, that well experienced lovers could recite.

Such of these griefs as might be refrained or holpen by wisdom and the parties' own good endeavour, the Poet gave none order to sorrow them. For first, as to the good renown: it is lost, for the more part, by some default of the owner, and may be by his well doings recovered again. And if it be unjustly taken away, as by untrue and famous libels, the offender's recantation may suffice for his amends. So did the Poet Stesichorus, as it is written of him in his Palinode upon the dispraise of Helena, and recovered his eyesight. Also for worldly goods they come and go, as things not long proprietary to anybody, and are not yet subject unto fortune's dominion so, but that we ourselves are in great part accessory to our own losses and hindrances, by oversight and misguiding of ourselves and our things; therefore why should we bewail our such voluntary detriment?

E.L. 
But death the irrecoverable loss, death the doleful departure of friends that can never be recontinued by any other meeting or new acquaintance. Besides, our uncertainty and suspicion of their estates and welfare in the places of their new abode seemeth to carry a reasonable pretext of just sorrow. Likewise the great overthrows in battle and desolations of countries by wars, as well for the loss of many lives and much liberty as for that it toucheth the whole state and every private man hath his portion in the damage. Finally for love, there is no frailty in flesh and blood so excusable as it, no comfort or discomfort greater than the good and bad success thereof, nothing more natural to man, nothing of more force to vanquish his will and to inveigle his judgment. Therefore of death and burials, of the adversities by wars, and of true love lost or ill bestowed, are the only sorrows that the noble Poets sought by their art to remove or appease, not with any medicament of a contrary temper, as the Galenists use to cure (contraria contrariis), but as the Paracelsians, who cure similia similibus making one dolour to expel another, and in this case, one short sorrowing the remedy of a long and grievous sorrow.

And the lamenting of deaths was chiefly at the very burials of the dead, also at months minds ${ }^{25}$ and longer times, by custom continued yearly, whenas they used many offices of service and love

25 Months-mind=monthly commemoration of the departed ; 'to have a months-mind' meant to have a strong inclination. Strikings, below, $=$ screechings. 
towards the dead, and thereupon are called Obsequies in our vulgar. Which was done not only by cladding the mourners, their friends and servants in black vestures, of shape doleful and sad, but also by woful countenances and voices, and besides by Poetical mournings in verse. Such funeral songs were called Epicedia if they were sung by many, and Monodia if they were uttered by one alone, and this was used at the interment of Princes and others of great account, and it was reckoned a great civility to use such ceremonies, as at this day is also in some country used. In Rome they accustomed to make orations funeral and commendatory of the dead parties in the public place called Procostris ; and our Theologians, instead thereof, use to make sermons, both teaching the people some good learning and also saying well of the departed.

Those songs of the dolorous discomforts in battle and other desolations in war, or of towns sackaged and subverted, were sung by the remnant of the army overthrown, with great skrikings and outcries, holding the wrong end of their weapon upwards in sign of sorrow and despair. The cities also made general mournings and offered sacrifices with Poetical songs to appease the wrath of the martial gods and goddesses.

The third sorrowing was of loves, by long lamentation in Elegie. So was their song called, and it was in a piteous manner of metre, placing a limping Pentameter after a lusty Hexameter, which made it go dolorously more than any other metre. 


\section{CHAPTER XXV}

OF THE SOLEMN REJOICINGS AT THE NATIVITY OF PRINCES' CHILDREN.

To return from sorrow to rejoicing it is a very good hap and no unwise part for him that can do it. I say, therefore, that the comfort of children is so natural and so great, not only to all men but specially to Princes, that duty and civility have made it a common custom to rejoice at the birth of their noble children, and to keep those days hallowed and festival for ever once in the year, during the parents' or children's lives; and that by public order and consent. Of which rejoicings and mirths the Poet ministered the first occasion honourable, by presenting of joyful songs and ballads, praising the parents by proof, the child by hope, the whole kindred by report, and the day itself with wishes of all good success, long life, health and prosperity for ever to the new-born. These poems were called in Greek Genethliaca; with us they may be called natal or birth-songs.

\section{CHAPTER XXVI}

THE MANNER OF REJOICINGS AT MARRIAGES AND WEDDINGS.

As the consolation of children well-begotten is great, no less but rather greater ought to be that which is occasion of children, that is honourable 
matrimony, a love by all laws allowed, not mutable nor encumbered with such vain cares and passions as that other love, whereof there is no assurance but loose and fickle affection occasioned for the most part by sudden sights and acquaintance of no long trial or experience, nor upon any other good ground wherein any surety may be conceived. Wherefore the Civil Poet could do no less in conscience and credit than, as he had before done to the ballad of birth, now with much better devotion, to celebrate by his poem the cheerful day of marriages as well Princely as others.

For that hath always been accounted with every country and nation of never so barbarous people the highest and holiest of any ceremony appertaining to man; a match forsooth made for ever and not for a day, a solace provided for youth, a comfort for age, a knot of alliance and amity indissoluble. Great rejoicing was therefore due to such a matter and to so gladsome a time. This was done in ballad-wise as the natal song, and was sung very sweetly by Musicians at the chamber-door of the Bridegroom and Bride, and they were called Epithalamies as much to say as ballads at the bridal couch. For such as were sung at the board at dinner or supper were other Musics and not properly Epithalamies. 


\section{CHAPTER XXVII}

THE MANNER OF POESY BY WHICH THEY UTTERED THEIR BITTER TAUNTS AND PRIVY NIPS, OR WITTY SCOFFS AND OTHER MERRY CONCEITS.

But all the world could not keep, nor any civil ordinance to the contrary so prevail, but that men would and must needs utter their spleens in all ordinary matters also. Therefore the poet devised a pretty-fashioned poem short and sweet (as we are wont to say) and called it Epigramma, in which every merry-conceited man might without any long study or tedious ambage make his friend sport, and anger his foe, and give a pretty nip, or show a sharp conceit in few verses.

For this Epigram is but an inscription or writing made as it were upon a table, or in a window, or upon the wall or mantel of a chimney in some place of common resort ${ }^{28}$, where it was allowed every man might come, or be fitting to chat and prate, as now in our taverns and common tablinghouses, where many merry heads meet and scribble with ink, with chalk, or with a coal, such matters as they would every man should know and descant upon. Afterward the same came to be put in paper and in books, and used as ordinary missives, some of friendship, some of defiance, or as other messages of mirth.

26 The walls of ancient cities were scribbled over with epigrams of this kind, which took the place to some extent of modern hoardings and posters. At Pompeii some of these inscriptions can still be deciphered on the walls of the streets and houses. 
Martial was the chief of this skill among the Latins, and at these days the best Epigrams we find and of the sharpest conceit are those that have been gathered among the reliques of the two mute Satires in Rome, Pasquil and Marphorir which in time of Sede vacante when merry-conceited men listed to gibe and jest at the dead Pope or any of his Cardinals, they fastened them upon those Images which now lie in the open streets, and were tolerated, but after that term expired they were inhibited again. These inscriptions or Epigrams at their beginning had no certain author that would avouch them, some for fear of blame, if they were over saucy or sharp, others for modesty of the writer, as was that distich of Virgil which he set upon the palace gate of the emperor Augustus which I will recite for the briefness and quickness of it, and also for another event that fell out upon the matter worthy to be remembered. These were the verses:

Nocte pluit tota, redeunt spectacula mane Divisum imperium cum Iove Cæsar habet

which I have thus Englished:

It rains all night, early the shows return, God and Cæsar do reign and rule by turn.

As much to say, God showeth His power by the night rains, Cæsar his magnificence by the pomps of the day.

These two verses were very well liked, and brought to the Emperor's Majesty, who took great pleasure in them and willed the author should be 
known. A saucy courtier proffered himself to be the man, and had a good reward given him ; for the Emperor himself was not only learned, but of much munificence toward all learned men. Whereupon Virgil, seeing himself by his overmuch modesty defrauded of the reward that an impudent had gotten by abuse of his merit, came the next night, and fastened upon the same place this halfmetre, four times iterated. Thus :

Sic vos non vobis

Sic vos non vobis

Sic vos non vobis

Sic vos non vobis

And there it remained a great while because no man wist what it meant, till Virgil opened the whole fraud by this device. He wrote above the same half-metres this whole verse, hexameter :

Hos ego versiculos feci, tulit alter honores

and then finished the four half-metres thus:

Sic vos non vobis Sic vos non vobis Sic vos non vobis Sic vos non vobis
Fertis aratra boves

Vellera fertis oves

Mellificatis apes

Indificatis aves

and put to his name Publius Virgilius Maro ${ }^{27}$. This matter came by and by to the Emperor's ear, who taking great pleasure in the device called for Virgil, and gave him not only a present reward,

27 This story is told by Donatus in his Life of Virgil, where the thieving poet is stated to have been Bathyllus, and the date is fixed as 3 I B.C., after the Battle of Actium. 
with a good allowance of diet, but also held him for ever after upon larger trial he had made of his learning and virtue in so great reputation that he vouchsafed to give him the name of a friend (amicus) which among the Romans was so great an honour and special favour as all such persons were allowed to the Emperor's table, or to the Senator's who had received them (as friends) and they were the only men that came ordinarily to their boards, and solaced with them in their chambers and gardens when none other could be admitted.

\section{CHAPTER XXVIII}

OF THE POEM CALLED EPITAPH USED FOR MEMORIAL OF THE DEAD.

AN Epitaph is but a kind of Epigram only applied to the report of the dead person's estate and degree, or of his other good or bad parts, to his commendation or reproach, and is an inscription such as a man may commodiously write or engrave upon a tomb in few verses, pithy, quick and sententious for the passer-by to peruse, and judge upon without any long tarriance. So that if it exceed the measure of an Epigram, it is then (if the verse be correspondent) rather an Elegy than an Epitaph, which error many of these bastard rhymers commit, because they be not learned, nor (as we are wont to say) crafts-masters. For they make long and tedious discourses, and write them in large tables to be hanged up in Churches and chancels over the tombs of great 
men and others, which be so exceeding long as one must have half a day's leisure to read one of them, and must be called away before he come half to the end, or else be locked into the Church by the Sexton as I myself was once served reading an Epitaph in a certain Cathedral-Church of England.

They be ignorant of poesy that call such long tales by the name of Epitaphs; they might better call them Elegies, as I said before, and then ought neither to be engraven nor hanged up in tables. I have seen them nevertheless upon many honourable tombs of these late times erected, which do rather disgrace than honour either the matter or maker.

\section{CHAPTER XXIX}

A CERTAIN ANCIENT FORM OF POESY BY WHICH MEN DID USE TO REPROACH THEIR ENEMIES.

As friends be a rich and joyful possession, so be foes a continual torment and canker to the mind of man. And yet there is no possible means to avoid this inconvenience for the best of us all and he that thinketh he lives most blameless lives not without enemies, that envy him for his good parts, or hate him for his evil.

There be wise men, and of them the great learned man Plutarch, took upon them to persuade the benefit that men receive by their enemies, which, though it may be true in manner of paradox, yet I find man's frailty to be naturally such, and always hath been, that he 
cannot conceive it in his own case, nor show that patience and moderation in such griefs as becometh the man perfect and accomplished in all virtue. But, either in deed or by word, he will seek revenge against them that malice him, or practise his harms, specially such foes as oppose themselves to a man's loves. This made the ancient Poets to invent a means to rid the gall of all such vindictive men, so that they might be a-wrecked of their wrong, and never bely their enemy with slanderous untruths. And this was done by a manner of imprecation, or as we call it by cursing and banning of the parties, and wishing all evil to alight upon them, and though it never the sooner happened, yet was it great easement to the boiling stomach. They were called Dire, such as Virgil made against Battarus, and Ovid against Ibis. We Christians are forbidden to use such uncharitable fashions, and willed to refer all our revenges to God alone ${ }^{28}$.

\section{CHAPTER XXX}

OF SHORT EPIGRAMS CALLED POSIES.

THERE be also other like Epigrams that were sent usually for new year's gifts, or to be printed, or

28 The pious conclusion to this chapter was particularly inappropriate to the times in which, a few years later, literary squabbling and lampooning were to reach such great dimensions. Thomas Nash ( $1567-1601$ ) was notorious in this respect, and there was almost a duel between Sir Philip Sidney and the Earl of Oxford, while the Martin Marprelate controversy rained a deluge of pamphlets, scurrilous and abusive in the extreme. 
put upon their banqueting dishes of sugar-plate or of march-panes ${ }^{29}$, and such other dainty meats as by the courtesy and custom every guest might carry from a common feast home with him to his own house, and were made for the nonce. They were called Nenia or apophoreta, and never contained above one verse, or two at the most, but the shorter the better. We call them Posies, and do paint them now-a-days upon the back sides of our fruit trenchers of wood, or use them as devices in rings and arms and about such courtly purposes.

So have we remembered and set forth to your Majesty very briefly all the commended forms of the ancient Poesy, which we in our vulgar makings do imitate and use under these common names : interlude, song, ballad, carol and ditty : borrowing them also from the French allsaving this word (song) which is our natural Saxon English word. The rest, such as time and usurpation by custom have allowed us out of the primitive Greek and Latin, as Comedy, Tragedy, Ode, Epitaph, Elegy, Epigram, and other more. And we have purposely omitted all nice or scholastical curiosities not meet for your Majesty's contemplation in this our vulgar art, and what we have written of the ancient forms of Poems we have taken from the best clerks writing in the same art ${ }^{30}$.

29 Elizabethan dessert delicacies.

30 We have no knowledge of Queen Elizabeth's attitude towards this treatise which seems to have been addressed to her more personally than to a patron in the conventional sense. Puttenham 'covertly deprecates exact scholarship : his summaries in the preceding chapters are popular 
The part that next followeth, to wit of proportion, because the Greeks nor Latins never had it in use nor made any observation no more than we do of their feet, we may truly affirm to have been the first devisers thereof ourselves

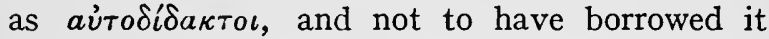
of any other by learning or imitation, and thereby trusting to be holden the more excusableif anything in this our labours happen either to mislike, or to come short of author's purpose, because commonly the first attempt in any art or engine artificial is amendable, and in time by often experiences reformed. And so no doubt may this devise of ours be by others that shall take the pen in hand after us.

\section{CHAPTER XXXI}

WHO IN ANY AGE HAVE BEEN THE MOST COMMENDED WRITERS IN OUR ENGLISH POESY, AND THE AUTHOR'S CENSURE GIVEN UPON THEM.

Ir appeareth by sundry records of books both printed and written that many of our countrymen have painfully travailed in this part, of whose works some appear to be but bare translations, other some matters of their own invention and very commendable, whereof some recital shall be made in this place, to the intent chiefly that their names should not be defrauded of such

in form. The next part, dealing with proportion, is not included in this reprint; it contained much technical matter somewhat antiquated to-day. 
honour as seemeth due to them for having by their thankful studies so much beautified our English tongue that at this day it will be found our nation is in nothing inferior to the French or Italian for copy of language, subtlety of device, good method and proportion in any form of poem, but that they may compare with the most, and perchance pass a great many of them.

And I will not reach above the time of King Edward the Third, and Richard the Second for any that wrote in English metre, because before their times by reason of the late Norman conquest, which had brought into this Realm much alteration both of our language and laws, and therewithal a certain martial barbarousness, whereby the study of all good learning was so much decayed that long time after no man or very few intended to write in any laudable science; so that beyond that time there is little or nothing worth commendation to be found written in this art ${ }^{31}$.

And those of the first age were Chaucer and Gower, both of them as I suppose Knights. After whom followed John Lydgate, the monk of Bury, and that nameless, who wrote the Satire called Piers Plowman ${ }^{32}$. Next him followed Harding

31 Chaucer, it should be remembered, was nearer in date to Puttenham than Shakespeare is to ourselves. Moreover, when Puttenham was writing, Shakespeare had not yet arrived in London. These considerations should be borne in mind in estimating the value of the criticism that 'it will be found our nation is in nothing inferior to the French or Italian'.

32 The Vision of Piers the Plowman is now attributed to William Langland (1330 ? to 1400 ?) the details of whose life have been pieced together, by a kind of circular process, from the evidence supplied in this poem. It 
the Chronicler, then in King Henry the Eighth's times Skelton, (I wot not for what great worthness) surnamed the Poet Laureate. In the latter end of the same king's reign sprang up a new company of courtly makers, of whom Sir Thomas Wyat the elder and Henry Earl of Surrey were the two chieftains, who having travelled into Italy, and there tasted the sweet and stately measures and style of the Italian Poesy as novices newly crept out of the schools of Dante, Ariosto and Petrarch, they greatly polished our rude and homely manner of vulgar Poesy, from that it had been before, and for that cause may justly be said the first reformers of our English metre and style. In the same time or not long after was the Lord Nicholas Vaux, a man of much facility in vulgar makings.

Afterward in King Edward the Sixth's time came to be in reputation for the same faculty Thomas Sternehold, who first translated into English certain Psalms of David, and John Heywood the Epigrammatist, who for the mirth and quickness of his conceits more than for any good learning was in him came to be well benefited by the king. But the principal man in this profession at the same time was Master Edward Ferris ${ }^{33}$, a man of no less mirth and felicity that

dealt with social and philosophical matters in a discursive and irregular manner, and is not inaptly described here as a 'satire'.

33 'Edward Ferris' is doubtless George Ferrers (or Ferris), who was born about 1500 and died in I 579 , so recently indeed in relation to this treatise that the slip in the fore-name is somewhat remarkable. He was 'master of the King's pastimes ' in I $55 \mathrm{I}-2$ was a member 
way, but of much more skill and magnificence in his metre, and therefore wrote for the most part to the stage, in Tragedy and sometimes in Comedy or Interlude, wherein he gave the king so much good recreation, as he had thereby many good rewards.

In Queen Mary's time flourished above any other Doctor Phaer, one that was well learned, and excellently well translated into English verse Heroical certain books of Virgil's EEneid. Since him followed Master Arthur Golding, who with no less commendation turned into English metre the Metamorphosis of Ovid and that other Doctor, who made the supplement to those books of Virgil's ZEneid, which Master Phaer left undone ${ }^{34}$.

And in her Majesty's time that now is are sprung up another crew of Courtly makers, Noble men and Gentlemen of her Majesty's own servants, who have written excellently well, as it would appear if their doings could be found out and made public with the rest, of which number is first that noble Gentleman Edward Earl of Oxford. Thomas Lord of Buckhurst, when he was young, Henry Lord Paget, Sir Philip Sidney, Sir Walter Ralegh, Master Edward Dyer, Master

of Parliament for many years, and is chiefly remembered to-day as the compiler with William Baldwin of The Mirror of Magistrates, a valuable series of moral and historical sketches in verse, completed in 1578 , under the general authorship of Thomas Sackville, Lord Buckhurst.

34 Thomas Twyne (1543-1613) translated the three books (part of x, xI and XII) of The Aeneid, left undone by Thomas Phaer (1510? -1560). Arthur Golding's dates were about $1536-1605$. His version of Ovid is celebrated as having been much used by Shakespeare. 
Fuike Grevell, Gascon, Britton, Turberville and a great many other learned Gentlemen, whose names I do not omit for envy, but to avoid tediousness, and who have deserved no little commen. dation. But of them all particularly this is my opinion, that Chaucer, with Gower, Lydgate and Harding for their antiquity ought to have the first place, and Chaucer as the most renowned of them all, for the much learning appeareth to be in him above any of the rest. And though many of his books be but bare translations out of the Latin and French, yet are they well handled, as his books of Troilus and Cresseid, and the Romant of the Rose, whereof he translated but one half, the device was John de Mehun's a French Poet. The Canterbury Tales were Chaucer's own invention as I suppose, and where he showeth more the natural of his pleasant wit than in any other of his works, his similitudes, comparisons and all other descriptions are such as cannot be amended. His metre Heroical of Troilus and Cresseid is very grave and stately, keeping the staff of seven, and the verse of ten, his other verses of the Canterbury Tales be but riding rhyme, nevertheless very well becoming the matter of that pleasant pilgrimage in which every man's part is played with much decency.

Gower, saving for his good and grave moralities, had nothing in him highly to be commended, for his verse was homely and without good measure, his words strained much deal out of the French writers, his rhyme wrested, and in his inventions small subtlety: the applications of his moralities are the best in him, and yet those many times very

E.L. 
grossly bestowed, neither doth the substance of his works sufficiently answer the subtlety of his titles. Lydgate a translator only and no deviser of that which he wrote, but one that wrote in good verse. Harding, a Poet Epic or Historical, handled himself well according to the time and manner of his subject. He that wrote the Satire of Piers Ploughman seemed to have been a malcontent of that time, and therefore bent himself wholly to tax the disorders of that age, and specially the pride of the Roman Clergy, of whose fall he seemeth to be a very true Prophet. His verse is but loose metre, and his terms hard and obscure, so that in them is little pleasure to be taken. Skelton, a sharp Satirist, but with more railing and scoffery than became a Poet Laureate, such among the Greeks were called Pantomimi, with us Buffoons, altogether applying their wits to scurrilities and other ridiculous matters. Henry Earl of Surrey and Sir Thomas Wyat, between whom I find very little difference, I repute them (as before) for the two chief lanterns of light to all others that have since employed their pens upon English Poesy; their conceits were lofty, their styles stately, their conveyance cleanly, their terms proper, their metre sweet and wellproportioned, in all imitating very naturally and studiously their Master Francis Petrarch. The Lord Vaux his commendation lieth chiefly in the facility of his metre, and the aptness of his descriptions such as he taketh upon him to make, namely in sundry of his Songs, wherein he showeth the counterfeit action very lively and pleasantly.

Of the later sort I think thus : That for Tragedy 
the Lord of Buckhurst and Master Edward Ferris for such doings as I have seen of theirs do deserve the highest price. The Earl of Oxford and Master Edwards of her Majesty's Chapel for Comedy and Interlude. For Eclogue and pastoral Poesy, Sir Philip Sidney and Master Challenner, and that other Gentleman who wrote the late Shepherd's Calendar ${ }^{35}$. For ditty and amorous Ode I find Sir Walter Ralegh's vein most lofty, insolent, and passionate. Master Edward Dyer for Elegy most sweet, solemn, and of high conceit. Gascon for a good metre and for a plentiful vein. Phaer and Golding for a learned and well corrected verse, specially in translation clear and very faithfully answering their author's intent.

Others have also written with much facility, but more commendably perchance if they had not written so much nor so popularly. But last in recital and first in degree is the Queen our sovereign Lady, whose learned, delicate, noble Muse easily surmounteth all the rest that have written before her time or since, for sense, sweetness and subtlety, be it in Ode, Elegy, Epigram, or any other kind of poem Heroic or Lyric, wherein it shall please her Majesty to employ her pen, even by as much odds as her own excellent estate and degree exceedeth all the rest of her most humble vassals.

35 Edmund Spenser: Sidney and Webbe have more to say about this 'other gentleman'. The concluding sentence in this discourse was doubtless in good taste at the time of its composition. 



\section{WILLIAM WEBBE}

\section{A DISCOURSE OF ENGLISH POETRY}

INTENDING to write some discourse of English Poetry, I think it not amiss if I speak something generally of Poetry, as, what it is, whence it had the beginning, and of what estimation it hath always been and ought to be among all sorts of

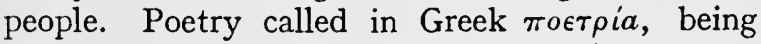
derived from the Verb $\pi$ oi $\epsilon \omega$, which signifieth in Latin facere, in English, to make, may properly be defined, the art of making ${ }^{1}$ : which word as it hath always been especially used of the best of our English Poets, to express the very faculty of speaking or writing Poetically, so doth it indeed contain most fitly the whole grace and property of the same, the more fully and effectually than any other English Verb. That Poetry is an Art (or rather a more excellent thing than can be contained within the compass of Art) though I need not stand long to prove, both the witness of Horace, who wrote de Arte Poetica, and of Terence,

1 This is the conventional opening, which varies hardly at all from that of Sidney or Puttenham. 
who calleth it Artem Musicam, and the very natural property thereof may sufficiently declare.

The beginning of it, as appeareth by Plato, was of a virtuous and most devout purpose, who witnesseth, that by occasion of meeting of a great company of young men, to solemnize the feasts which were called Panegerica and were wont to be celebrated every fifth year there, they that were most pregnant in wit, and indued with great gifts of wisdom and knowledge in Music above the rest did use commonly to make goodly verses, measured according to the sweetest notes of Music, containing the praise of some noble virtue, or of immortality, or of some such thing of greatest estimation: which unto them seemed so heavenly and joyous a thing that, thinking such men to be inspired with some divine instinct from heaven, they called them Vates. So when other among them of the finest wits and aptest capacities began in imitation of these to frame ditties of lighter matters, and tuning them to the stroke of some of the pleasantest kind of Music, then began there to grow a distinction and great diversity between makers and makers. Whereby (I take it) began this difference: that they which handled in the audience of the people grave and necessary matters were called wise men or eloquent men, which they meant by Vates : and the rest which sang of love matters, or other lighter devices alluring unto pleasure and delight, were called Poete or makers ${ }^{2}$.

2 Webbe's distinction between vates and poetaprophecy and poetry-has no particular value. Like other verbal hair-splitting, carried further in Puttenham than in Sidney, but noticeable in both, it differs from 
Thus it appeareth, both Eloquence and Poetry to have had their beginning and original from these exercises, being framed in such sweet measure of sentences and pleasant harmony called Rhythmos, which is an apt composition of words or clauses, drawing as it were by force the hearer's ears even whithersoever it listeth: that Plato affirmeth therein to be contained 'an enchantment', as it were, to persuade them anything, whether they would or no. And herehence is said that men were first withdrawn from a wild and savage kind of life, to civility and gentleness, and the right knowledge of humanity by the force of this measurable or tunable speaking.

This opinion shall you find confirmed throughout the whole works of Plato and Aristotle. And that such was the estimation of this Poetry at those times, that they supposed all wisdom and knowledge to be included mystically in that divine

modern methods of criticism by caring too much for the letter and too little for the spirit. The knowledge-value does not lie in the words, but in the intention and the meaning attached to them. The root of the matter is not here, and Professor Saintsbury, though he admits that 'Webbe, to the best of his modest powers, was a devotee of literature ', takes a short cut through what he describes as 'the usual etymological definition of poetry as making, and the usual comments on the word vates' (History of Criticism, Vol. ii, Ch. 5, Blackwood).

On the suggested distinction in this paragraph between eloquence and poetry, John Stuart Mill has a little-known but memorable remark in his essay on 'Poetry and Its Varieties': 'Poetry and eloquence are both alike the expression or utterance of feeling. But, if we may be excused the antithesis, we should say that eloquence is heard, poetry is overheard ' (Dissertations and Discussions I, 57, Routledge). 
instinction, wherewith they thought their Vates to be inspired. Whereupon, throughout the noble works of those most excellent Philosophers before named, are the authorities of Poets very often alleged. And Cicero in his Tusculan questions is of that mind, that a Poet cannot express verses abundantly, sufficiently, and fully, neither his eloquence can flow pleasantly, or his words sound well and plenteously, without celestial instinction : which Poets themselves do very often and gladly witness of themselves, as namely Ovid in the sixth book of his Fasti: Est deus in nobis agitante calescimus illo, etc. Whereunto I doubt not equally to adjoin the authority of our late famous English Poet, who wrote the Shepherd's Calendar, where, lamenting the decay of Poetry at these days, saith most sweetly to the same :

Then make thee wings of thine aspiring wit,

And, whence thou camest, fly back to heaven apace.

Whose fine poetical wit and most exquisite learning, as he showed abundantly in that piece of work, in my judgment inferior to the works neither of Theocritus in Greek, nor Virgil in Latin, whom he narrowly imitateth : so I nothing doubt, but if his other works were common abroad, which are as I think in the close custody of certain his friends, we should have of our own Poets, whom we might match in all respects with the best. And among all other his works whatsoever, I would wish to have the sight of his English Poet, which his friend ' $\mathrm{E}$. K.' did once promise to publish, which whether he performed or not I know not, 


\section{A Discourse of English Poetry}

if he did, my hap hath not been so good as yet to see it $^{3}$.

But to return to the estimation of Poetry. Besides the great and profitable fruits contained in Poetry, for the instruction of manners and precepts of good life (for that was chiefly respected in the first age of Poetry) this is also added to the eternal commendations of that noble faculty : that Kings and Princes, great and famous men, did ever encourage, maintain, and reward Poets in all

${ }^{3}$ The lines occur in the Tenth Eclogue (October) of Spenser's Shepherd's Calendar. Pierce is speaking:

O peerless Poesy! where is then thy place?

If nor in Prince's palace thou do sit

(And yet is Prince's palace the most fit),

Nor breast of baser birth doth thee embrace,

Then make thee wings of thine aspiring wit,

And, whence thou camest, fly back to Heaven apace.

Note that Webbe does not agree with Sidney (see p. 93 supra), who 'dared not allow' the rustic language of this poem because 'neither Theocritus, nor Virgil affected ' it. As Sidney's treatise was circulated in MS., it is extremely probable that Webbe is directly referring to that criticism in this passage.

'E.K.' is Edward Kirke, a College friend of Spenser's, who supervised the publication of The Shepherd's Calendar, supplying it liberally with notes, dedicatory epistles, glosses, and so forth. In the note prefatory to this Ioth eclogue, Kirke explained the argument as a defence of poetry, which a 'heavenly instinct. . poured into the wit by a certain . . . celestial inspiration, as the Author hereof (Spenser) elsewhere at large discourseth in his book called The English Poet, which book being lately come to my hands I mind also by God's grace upon further advisement to publish'. There is no record of its publication, though, like Webbe, we should be glad to see it. Note that the same need to apologize for poetry operated in Spenser as in the authors of these treatises, but, as Webbe had the wit to see, Spenser's own poetry was the best reply to Gosson and his school. 
ages : because they were thought only to have the whole power in their hands of making men either immortally famous for their valiant exploits and virtuous exercises, or perpetually infamous for their vicious lives. Whereupon it is said of Achilles, that this only vantage he had of Hector, that it was his fortune to be extolled and renowned by the heavenly verse of Homer. And as Tully recordeth to be written of Alexander, that with natural tears he wept over Achilles' Tomb, in joy that he conceived at the consideration, how it was his hap to be honoured with so divine a work, as Homer's was. Aristotle, a most prudent and learned Philosopher, being appointed Schoolmaster to the young Prince Alexander, thought no work so meet to be read unto a King as the work of Homer : wherein the young Prince being by him instructed thoroughly, found such wonderful delight in the same when he came to maturity, that he would not only have it with him in all his journeys, but in his bed also under his pillow, to delight him and teach him both nights and days. The same is reported of noble Scipio, who finding the two Books of Homer in the spoil of King Darius, esteemed them as wonderful precious jewels, making one of them his companion for the night, the other for the day. And not only was he thus affected to that one piece or part of Poetry, but so generally he loved the professors thereof that in his most serious affairs and hottest wars against Numantia and Carthage he could no whit be without that old Poet Ennius in his company. But to speak of all those noble and wise Princes who bare special favour and countenance to Poets 
were tedious, and would require a rehearsal of all such in whose time there grew any to credit and estimation in that faculty. Thus far therefore may suffice for the estimation of Poets. Now I think most meet to speak somewhat concerning what hath been the use of Poetry, and wherein it rightly consisted, and whereof consequently it obtained such estimation.

To begin therefore with the first that was first worthily memorable in the excellent gift of Poetry, the best writers agree that it was Orpheus, who by the sweet gift of his heavenly Poetry withdrew men from ranging uncertainly and wandering brutishly about, and made them gather together, and keep company, made houses, and kept fellowship together, who therefore is reported (as Horace saith) to assuage the fierceness of Tigers, and move the hard flints. After him was Amphion, who was the first that caused Cities to be builded, and men therein to live decently and orderly according to law and right. Next was Tyrtæus, who began to practise warlike defences, to keep back enemies, and save themselves from invasion of foes. In this place I think were most convenient to rehearse that ancient Poet Pindar : but of the certain time wherein he flourished I am not very certain $^{4}$ : but of the place where he continued most, it should seem to be the City of Thebes, by Pliny, who reporteth that Alexander, in sacking the same City, would not suffer the house wherein he dwelt to be spoiled as all the rest were. After these was Homer, who as it were in one sum

4 The date commonly given is the century $522-422$ B.C. 
comprehended all knowledge, wisdom, learning, and policy, that was incident to the capacity of man. And who so list to take view of his two Books, one of his Iliad, the other his Odyssy, shall thoroughly perceive what the right use of Poetry is : which indeed is to mingle profit with pleasure, and so to delight the Reader with pleasantness of his Art, that in the meantime his mind may be well instructed with knowledge and wisdom. For so did that worthy Poet frame those his two works, that in reading the first, that is his Iliad, by declaring and setting forth so lively the Grecians' assembly against Troy, together with their prowess and fortitude against their foes, a Prince shall learn not only courage, and valiantness, but discretion also and policy to encounter with his enemies, yea a perfect form of wise consultations with his captains, and exhortations to the people, with other infinite commodities.

Again, in the other part, wherein are described the manifold and dangerous adventures of Ulysses, may a man learn many noble virtues: and also learn to escape and avoid the subtle practices, and perilous entrappings of naughty persons : and not only this, but in what sort also he may deal to know and perceive the affections of those which be near unto him, and most familiar with him, the better to put them in trust with his matters of weight and importance. Therefore I may boldly set down this to be the truest, ancientest and best kind of Poetry, to direct one's endeavour always to that mark, that with delight they may evermore adjoin commodity to their readers : which because I ground upon Homer the Prince of all Poets, 
therefore have I alleged the order of his work, as an authority sufficiently proving this assertion.

Now what other poets which followed him, and been of greatest fame, have done for the most part in their several works I will briefly, and as my slender ability will serve me, declare. But by my leave, I must content myself to speak not of all, but of such as myself have seen, and been best acquainted withal, and those not all nor the most part of the ancient Grecians, of whom I know not how many there were, but these of the Latinists, which are of greatest fame and most obvious among us.

Thus much I can say, that Aristotle reporteth none to have greatly flourished in Greece, at leastwise not left behind them any notable memorial, before the time of Homer. And Tully saith as much, that there were none writ worth the reading twice in the Roman tongue, before the Poet Ennius. And surely as the very sum or chiefest essence of Poetry did always for the most part consist in delighting the readers or hearers with pleasure, so, as the number of Poets increased, they still inclined this way rather than the other, so that most of them had special regard to the pleasantness of their fine conceits, whereby they might draw men's minds into admiration of their inventions, more than they had to the profit or commodity that the readers should reap by their works. And thus as I suppose came it to pass among them, that for the most part of them, they would not write one work containing some serious matter: but for the same they would likewise pour forth as much of some wanton or lascivious 
invention. Yet some of the ancientest sort of Grecians, as it seemeth, were not so much disposed to vain delectation: as Aristotle saith of Empedocles, that in his judgment he was only a natural philosopher, no poet at all, nor that he was like unto Homer in anything but his metre, or number of feet, that is, that he wrote in verse. After the time of Homer, there began the first Comedy writers, who compiled their works in a better style, which continued not long before it was expelled by penalty, for scoffing too broad at men's manners, and the privy revengements which the Poets used against their ill-willers. Among these was Eupolis, Cratinus, and Aristophanes, but afterward the order of this writing Comedies was reformed and made more plausible: then wrote Plato, Comicus, Menander, and I know not who more.

There be many most profitable works, of like antiquity, or rather before them, of the Tragedy writers : as of Euripides, and Sophocles; then was there Phocitides and Theagines, with many other: which Tragedies had their invention by one Thespis, and were polished and amended by Eschylus. The profit or discommodity which ariseth by the use of these Comedies and Tragedies, which is most, hath been long in controversy, and is sore urged among us at these days ${ }^{5}$ : what I think of the same, perhaps I shall briefly declare anon.

Now concerning the Poets which wrote in

5 In reference once more to Gosson and the Puritanic objectors to stage performances. 
homely manner, as they pretended, but indeed, with great pith and learned judgment, such as were the writers of Shepherds' talk and of husbandly precepts, who were among the Grecians that excelled, besides Theocritus and Hesiodus I know not, of whom the first, what profitable works he left to posterity, besides his Idyllia or contentions of Goatherds, tending most to delight, and pretty inventions, I cannot tell ${ }^{6}$. The other, no doubt for his Argument he took in hand, dealt very learnedly and profitably, that is, in precepts of Husbandry, but yet so as he mixed much wanton stuff among the rest.

The first writers of Poetry among the Latins, should seem to be those which excelled in the framing of Comedies, and that they continued a long time without any notable memory of other Poets. Among whom, the chiefest that we may see or hear tell of, were these: Ennius, Cæcilius Nævius, Licinius, Attilius, Turpitius, Trabea, Luscius, Plautus, and Terence. Of whom these two last-named have been ever since their time most famous, and to these days are esteemed, as great helps and furtherances to the obtaining of good Letters. But here cannot I stay to speak of the most famous, renowned and excellent that ever wrote among the Latin Poets, P. Virgil, who performed the very same in that tongue which Homer had done in Greek : or, rather, better (if better might), as Propertius in his Elegies gallantly recordeth in his praise, Nescio quid magis

6 Webbe is quite frank in this place and above-'the ancient Grecians, of whom I know not how many there were '-as to his comparative ignorance of Greek literature. 
nascitur Iliade. Under the person of Æneas he expresseth the valour of a worthy Captain and valiant Governor, together with the perilous adventures of war, and politic devises at all assays. And as he imitateth Homer in that work, so doth he likewise follow the very steps of Theocritus, in his most pithy inventions of his Eclogues: and likewise Hesiod in his Georgics or books of Husbandry, but yet more gravely, and in a more decent style. But notwithstanding his sage gravity and wonderful wisdom, did he not altogether restrain his vein, but that he would have a cast at some wanton and scant comely an Argument, if indeed such trifles as be fathered upon him were his own ${ }^{7}$. There followed after him very many rare and excellent Poets, whereof the most part wrote light matters, as Epigrams and Elegies, with much pleasant dalliance, among whom may be accounted Propertius, Tibullus, Catullus, with divers whom Ovid speaketh of in divers places of his works. Then are there two Historical Poets no less profitable than delightsome to be read: Silius and Lucan : the one declaring the valiant prowess of two noble Captains, one enemy to the other, that is, Scipio and Hannibal: the other likewise, the fortitude of two expert warriors (yet more lamentably than the other because these wars were civil) Pompey and Cæsar ${ }^{8}$. The

7 Webbe, who is plainly a much better Roman scholar than Greek, is referring to the stories told in Donatus' life of Virgil and elsewhere. Such a story was quoted by Puttenham (p. I 84 supra), and it is perhaps that passage which Webbe had directly in mind.

8 Silius Italicus ( 25 to IOO A.D.) wrote a heroic poem on the Punic Wars, Punica; Lucan ( 39 to 65 A.D.) wrote one 


\section{A Discourse of English Poetry|}

next in time (but as most men do account, and so did he himself) the second in dignity, we will adjoin Ovid, a most learned and exquisite Poet. The work of greatest profit which he wrote, was his Book of Metamorphosis which, though it consisted of feigned Fables for the most part and poetical inventions, yet being moralized according to his meaning, and the truth of every tale being discovered, it is a work of exceeding wisdom and sound judgment. If one list in like manner to have knowledge and perfect intelligence of those rites and ceremonies which were observed after the Religion of the Heathen, no more profitable work for that purpose than his books De fastis. The rest of his doings, though they tend to the vain delights of love and dalliance (except his Tristibus wherein he bewaileth his exile) yet surely are mixed with much good counsel and profitable lessons if they be wisely and narrowly read. After his time I know no work of any great fame, till the time of Horace, a Poet not of the smoothest style, but in sharpness of wit inferior to none, and one to whom all the rest both before his time and since, are very much beholding. About the same time Juvenal and Persius, then Martial, Seneca-a most excellent writer of Tragedies-Boetius, Lucretius, Statius, Valerius Flaccus, Manilius, Ausonius, Claudian, and many other, whose just times and

on Cæsar and Pompey, Pharsalia, starting after the crossing of the Rubicon. We gather that, like many Elizabethans, Webbe's Latinity was confined chiefly to Ovid and writers of the Silver period. He seems quite at home with Ovid, though his reference to 'Propertius, Tibullus, Catallus, with divers whom Ovid speaketh of ' is plainly perfunctory.

E.L. 
several works to speak of in this place were neither much needful, nor altogether tolerable, because I purposed another argument. Only I will add two of later times, yet not far inferior to the most of them aforesaid, Pallengenius, and Bap. Mantuanus, and for a singular gift in a sweet heroical verse match with them Chr. Oclan, the author of our Anglorum Prolia ${ }^{9}$. But now lest I stray too far from my purpose, I will come to our English Poets, to whom I would I were able to yield their deserved commendations, and afford them that censure, which I know many would, which can better, if they were now to write in my stead.

I know no memorable work written by any Poet in our English speech, until twenty years past: where, although learning was not generally decayed at any time, especially since the Conquest of King William Duke of Normandy, as it may appear by many famous works and learned books (though not of this kind) written by Bishops and others, yet surely that Poetry was in small price among them, it is very manifest, and no great marvel, for even that light of Greek and Latin Poets which they had they much contemned, as appeareth by their rude versifying, which of long time was used (a barbarous use it was) wherein they converted

9 This digression is even less ' tolerable'-Webbe having 'purposed another argument '- than the catalogue of Latinists just above. Christopher Ocland, or Oclan, who died about I590, was a country schoolmaster, who wrote Latin poetical exercises on Queen Elizabeth, on controversial topics, etc. His Battles of the English (Anglorum Proelia) of 1580 was a Latin text in grammarschools, and there is more than a suspicion of 'log-rolling' in Webbe's inclusion thereof in a list which began with Ennius and Virgil. 


\section{A Discourse of English Poetry}

the natural property of the sweet Latin verse, to be a bald kind of rhyming, thinking nothing to be learnedly written in verse, which fell not out in rhyme, that is, in words whereof the middle word of each verse should sound alike with the last, or of two verses, the end of both should fall in the like letters as thus :

O male viventes, versus audite sequentes.

And thus likewise :

Propter hæc et alia dogmata doctorum

Reor esse melius et magis decorum :

Quisque suam habeat, et non proximorum.

This brutish Poetry, though it had not the beginning in this Country, yet so hath it been affected here, that the infection thereof would never (nor I think ever will) be rooted up again : I mean this tinkerly verse which we call rhyme. Master Ascham saith, that it first began to be followed and maintained among the Huns and Gothians, and other barbarous nations, who with the decay of all good learning brought it into Italy : from thence it came into France, and so to Germany, at last conveyed into England by men indeed of great wisdom and learning, but not considerate nor circumspect in that behalf. But of this I must intreat more hereafter.

Henry the first king of that name in England, is wonderfully extolled in all ancient Records of memory, for his singular good learning in all kind of noble studies, insomuch that he was named by his surname Beauclerk, as much to say as Fair. 
clerk (whereof perhaps came the name of Fair. clough). What knowledge he attained in the skill of Poetry, I am not able to say : I report his name for proof that learning in this Country was not little esteemed of at that rude time, and that like it is, among other studies, a king would not neglect the faculty of Poetry. The first of our English Poets that I have heard of was John Gower, about the time of King Richard the Second, as it should seem by certain conjectures both a Knight, and questionless a singular well-learned man: whose works I could wish they were all whole and perfect among us, for no doubt they contained very much deep knowledge and delight: which may be gathered by his friend Chaucer, who speaketh of him oftentimes, in divers places of his works. Chaucer, who for that excellent fame which he obtained in his Poetry was always accounted the 'God' of English Poets (such a title for honour's sake hath been given him) was next after, if not equal in time to Gower, and hath left many works, both for delight and profitable knowledge, far exceeding any other that as yet ever since his time directed their studies that way. Though the manner of his style may seem blunt and coarse to many fine English ears at these days, yet in truth, if it be equally pondered, and with good judgment advised, and confirmed with the time wherein he wrote, a man shall perceive thereby even a true picture or perfect shape of a right Poet. He by his delightsome vein, so gulled the ears of men with his devices that, although corruption bare such sway in most matters, that learning and truth might scant be admitted to show itself, yet 
without controlment, might he gird at the vices and abuses of all states, and gall with very sharp and eager inventions, which he did so learnedly and pleasantly, that none therefore would call him into question. For such was his bold spirit, that what enormities he saw in any, he would not spare to pay them home, either in plain words, or else in some pretty and pleasant covert, that the simplest might espy him.

Near in time unto him was Lydgate, a Poet surely for good proportion of his verse, and meetly current style, as the time afforded, comparable with Chaucer, yet more occupied in superstitious and odd matters, than was requisite in so good a wit: which, though he handled them commendably, yet the matters themselves being not so commendable, his estimation hath been the less. The next of our ancient Poets, that I can tell of, I suppose to be Piers Ploughman, who in his doings is somewhat harsh and obscure, but indeed a very pithy writer, and (to his commendation I speak it) was the first that I have seen that observed the quantity of our verse without the curiosity of rhyme.

Since these I know none other till the time of Skelton, who wrote in the time of King Henry the Eighth, who, as indeed he obtained the Laurel Garland, so may I with good right yield him the title of a Poet: he was doubtless a pleasant conceited fellow, and of a very sharp wit, exceeding bold, and would nip to the very quick where he once set hold. Next him I think I may place master George Gascoigne, as painful a soldier in the affairs of his Prince and country as he was a 
witty poet in his writing : whose commendations, because $I$ found in one of better judgment than myself, I will set down his words, and suppress my own. Of him thus writeth 'E. K.' upon the ninth Eclogue of the new Poet:

Master George Gascoigne a witty gentleman and the very chief of our late rhymers, who and if some parts of learning wanted not (albeit is well known he altogether wanted not learning) no doubt would have attained to the excellency of those famous Poets. For gifts of wit and natural promptness appear in him abundantly.

I might next speak of the divers works of the old Earl of Surrey, of the Lord Vaux, of Norton, of Bristow, Edwardes, Tusser, Churchyard, Will. Hunnis, Heywood, Sanders, Hyll, S. Y. M. D., and many others, but to speak of their several gifts, and abundant skill showed forth by them in many pretty and learned works would make my discourse much more tedious ${ }^{10}$.

I may not omit the deserved commendations of many honourable and noble Lords, and Gentlemen, in her Majesty's Court, which in the rare devices of Poetry have been and yet are most excellent

10 The names of the Elizabethan writers mentioned in this paragraph will be found in any good history, with the exceptions of William Hunnis, who died in 1597 , and was the author of metrical psalms and other works ; Nicholas Sanders or Sander (Webbe's Ed. pr. has 'Sand ' :) who died in $158 \mathrm{I}$, and was an historical writer and Roman Catholic controversialist; and Hyll, who is, perhaps, to be identified with Adam Hill (died I 595), a prebendary of Salisbury. No conjecture is offered as to the initials S.Y.M.D. Richard Bristow (died 1581 ) was, like Sander, a Roman Catholic divine, and the only names in this list whose works posterity cares to read are Surrey and Vaux, though Gascoigne, Tusser, Churchyard and Heywood have distinct places in English literature. 
skilful, among whom the right honourable Earl of Oxford may challenge to himself the title of the most excellent among the rest. I can no longer forget those learned gentlemen which took such profitable pains in translating the Latin Poets into our English tongue, whose deserts in that behalf are more than I can utter. Among these, I ever esteemed, and while I live, in my conceit I shall account Master D. Phaer: without doubt the best : who as indeed he had the best piece of poetry whereon to set a most gallant verse, so performed he it accordingly, and in such sort, as in my conscience I think would scarcely be done again, if it were to do again. Notwithstanding, I speak it but as mine own fancy, not prejudicial to those that list to think otherwise. His work whereof I speak is the Englishing of The Eneid of Virgil, so far forth as it pleased God to spare him life, which was to the half part of the tenth Book, the rest being since with no less commendations finished by that worthy scholar and famous physician Master Thomas Twyne.

Equally with him may I well adjoin Master Arthur Golding, for his labour in Englishing Ovid's Metamorphosis, for which gentleman surely our country hath for many respects greatly to give God thanks : as for him which hath taken infinite pains without ceasing, travelleth as yet indefatigably, and is addicted without society, by his continual labour, to profit this nation and speech in all kind of good learning. The next, very well deserveth Master Barnabe Googe to be placed, as a painful furtherer of learning: his help to Poetry besides his own devices, as the translating 
of Pallengenius Lodiac. Abraham Fleming, as in many pretty Poesies of his own, so in translating hath done to his commendations ${ }^{11}$. To whom I would here adjoin one of his name, whom I know to have excelled as well in all kind of learning as in Poetry most especially, and would appear so, if the dainty morsels and fine poetical inventions of his were as common abroad as I know they be among some of his friends. I will crave leave of the laudable Authors of Seneca in English, of the other parts of Ovid, of Horace, of Mantuan, and divers other, because I would hasten to end this rehearsal, perhaps offensive to some, whom either by forgetfulness, or want of knowledge, I must needs overpass.

And once again, I am humbly to desire pardon of the learned company of Gentlemen Scholars, and students of the Universities, and Inns of Court, if I omit their several commendations in this place, which I know a great number of them have worthily deserved, in many rare devices, and singular inventions of Poetry: for neither hath it been my good hap to have seen all which I have heard of, neither is my abiding in such place, where I can with facility get knowledge of their works.

One gentleman notwithstanding among them may I not overslip so far reacheth his fame, and so worthy is he, if he have not already, to wear the

11 Abraham Fleming (died 1607), wrote a digest of Holinshed and other works, besides translations. The ' one of his name' is unknown. Golding and Googe are historically well-known, the former as the author of Shakespeare's version of Ovid. 
Laurel wreath, Master George Whetstone, a man singularly well skilled in this faculty of Poetry. To him I will join Anthony Munday, an earnest traveller in this art, and in whose name I have seen very excellent works, among which surely, the most exquisite vein of a witty poetical head is showed in the sweet sobs of Shepherds and Nymphs - a work well worthy to be viewed, and to be esteemed as very rare Poetry. With these I may place John Grange, Knight, Wylmott, Darrell, F. C. F. K. G. B. and many other, whose names come not now to my remembrance ${ }^{12}$.

This place have I purposely reserved for one, who if not only, yet in my judgment principally deserveth the title of the rightest English Poet, that ever I read: that is, the Author of the Shepherd's Kalendar, intituled to the worthy gentleman Master Philip Sidney, whether it was Master $S p$. or what rare scholar in Pembroke Hall soever,

12 George Whetstone (c. I 544-1587) published a miscellaneous volume of tales, etc., in prose and verse, entitled Rock of Regard, in 1576; memorial verses on Gascoigne, Sir Philip Sidney and others; Promos and Cassandra, a play (never acted) which suggested the plot of Shakespeare's Measure for Measure, and other works and adaptations. He served twice in Holland, and took part in the Battle of Zutphen.

Anthony Munday (I553-1633) was author or partauthor of a large number of plays, ballads, romances, etc., very little of which survives. John Grange was the author of The Golden Aphroditis (I577), and the remaining names and initials are not much more worthy of mention than those, 'whose names come not now to my remembrance'. The catalogue-form of Webbe's list of names serves really to emphasize his selections of 'the new poet', Edmund Spenser, to whose Shepherd's Calendar he pays so just and so creditable a meed of admiration. 
because himself and his friends, for what respect I know not, would not reveal it, I force not greatly to set down: sorry I am that I cannot find none other with whom I might couple him in this Catalogue, in his rare gift of Poetry : although one there is, though now long since, seriously occupied in graver studies (Master Gabriel Harvey) yet, as he was once his most special friend and fellow poet, so because he hath taken such pains, not only in his Latin Poetry (for which he enjoyed great commendations of the best both in judgment and dignity in this Realm) but also to reform our English verse, and to beautify the same with brave devices, of which I think the chief lie hid in hateful obscurity: therefore will I adventure to set them together, as two of the rarest wits and learnedst masters of Poetry in England. Whose worthy and notable skill in this faculty, I would wish if their high dignities and serious businesses would permit, they would still grant to be a furtherance to that reformed kind of Poetry, which Master Harvey did once begin to ratify : and surely in mine opinion, if he had chosen some graver matter, and handled but with half that skill, which I know he could have done, and not poured it forth at a venture, as a thing between jest and earnest, it had taken greater effect than it did.

As for the other gentleman, if it would please him or his friends to let those excellent Poems, whereof I know he hath plenty, come abroad, as his Dreams, his Legends, his Court of Cupid, his English Poet with other : he should not only stay the rude pens of myself and others, but also satisfy 
the thirsty desires of many which desire nothing more, than to see more of his rare inventions. If I join to Master Harvey his two brethren, I am assured, though they be both busied with great and weighty callings (the one a godly and learned Divine, the other a famous and skilful physician) yet if they listed to set to their helping hands to Poetry, they would as much beautify and adorn it as any others ${ }^{13}$.

If I let pass the uncountable rabble of rhyming Ballad makers and compilers of senseless sonnets, who be most busy to stuff every stall full of gross

13 Gabriel Harvey (I 545-1630) was the 'father', as it were, of the Leicester House clique, self-styled The Areopagus. Webbe's collocation of his name with Spenser's was a natural error which lay in the circumstances of the time. It would have pleased Spenser at the moment, and would have informed the public of the aims and type of the new poet. Thus, however absurd it may sound to-day, it had critical justification. Harvey's brothers, John and Richard, were both Cambridge men, and are both described as astrologers.

The next two paragraphs are interesting in themselves, and in their references. The Barley-crown, in place of the Laurel, which Webbe would set on the head of the 'pottical' or ale-house poets was changed to purest bays when Shakespeare a year or two later became a member of the Mermaid circle. The 'rakehelly rout of our ragged rhymers' is a fine piece of alliterative scorn levelled at the euphuizing 'letter-hunters', of whom (in this context) Gosson was a chief offender. The opening 'In regard (he meaneth ....)' probably conceals a lost line : it is possible that Webbe referred directly here to some writer who would thus be the subject of 'he'.

The abrupt ending is due to the fact that Webbe goes on from here to an examination of 'The Matter of English Poetry (including a comparison of Phaer's Eneid with Virgil's original)', and then to lengthy considerations of metrical forms, into which he introduced meritorious but dull experiments of his own in English hexameters and sapphics. These portions of his Discourse are omitted. 
devices and unlearned pamphlets: I trust I shall with the best sort be held excused. Nor though many such can frame an alehouse song of five or six score verses, hobbling upon some tune of a Northen lygge, or Robin Hood, or La lubber, etc., and perhaps observe just number of syllables, eight in one line, six in another, and there withal an $\mathrm{A}$ to make a jerk in the end; yet if these might be accounted poets (as it is said some of them make means to be promoted to the Laurel) surely we shall shortly have whole swarms of poets : and every one that can frame a Book in Rhyme, though for want of matter it be but in commendations of copper noses or bottle ale, will catch at the Garland due to Poets: whose pottical poetical (I should say) heads, I would wish, at their worshipful commencements might, instead of Laurel, be gorgeously garnished with fair green barley, in token of their good affection to our English malt. One speaketh thus homely of them, with whose words I will content myself for this time, because I would not be too broad with them in mine own speech.

In regard (he meaneth of the learned framing the new Poet's works which wrote the Shepherd's Calendar): I scorn and spue out the rakehelly rout of our ragged Rhymers, (for so themselves use to hunt the Letter) which without learning boast, without judgment jangle, without reason rage and fume, as if some instinct of poetical spirit had newly ravished them, above the meanness of common capacity. And being in the midst of all their bravery, suddenly for want of matter or of Rhyme, or having forgotten their former conceit, 
A Discourse of English Poetry 22I

they seem to be so pained and travailed in their remembrance, as it were a woman in Childbirth, or as that same Pythia when the trance came upon her. Os rabidum fera corda domans, etc.

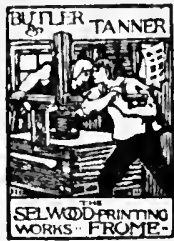





\section{Routledge's New Universal Library. 1s. net.}

Pott 8vo, olive-green cloth extra, full gilt back, 1s, net; olive-green lambskin gilt, gilt tops, silk register, $2 s$. net. Printed from accurate texts, entirely unabridged, and where necessary annotated and indexed.

ADAMNAN : Life of Saint Columba.

AESOP: Fables, \&c.

ANDERSEN : Fairy Tales.

ARISTOTLE: Ethics. Translated by Chasz.

ARNOLD (Matthew): On Translating Homer.

BACON : Essays.

- Novum Organum.

BARHAM : The Ingoldsby Legends.

BATES : Naturalist on the Amazons.

BRIMLEY : Essays. Edited by W. G. Clark, M.A. BROWN : Horae Subsecivae. Series I.

BROWNE (Sir T.): Religio Medici and Urn-burial. BROWNING (Robert): Poems.

BULFINCH : The Age of Fable.

BUNYAN : The Pilgrim's Progress.

BURKE: Thoughts on the Present Discontents.

CARLYLE: Heroes and Hero Worship.

- Sartor Resartus.

COLERIDGE : Aids to Reflection.

DARWIN : Voyage of a Naturalist.

DE QUINCEY: English Opium-Eater.

EMERSON : Essays.

FRASER (Sir William): Words on Wellington.

FROUDE: Dissolution of the Monasteries, \&c.

GASKELL (Mrs.): Life of Charlotte Brontë.

- - Sylvia's Lovers.

- Cranford.

GATTY: Parables from Nature.

Golden Treasury of American Songs and Lyrics.

GOLDSMITH : Citizen of the World.

GRIMM : Fairy Tales.

HARE : Guesses at Truth.

HARRIS: Uncle Remus.

- Nights with Uncle Remus.

HARTE (Bret): The Lnck of Roaring Camp.

HAWTHORNE : The Scarlet Letter.

[Consinued on p. 
New Universal Library (continued).

HOBBES : Leviathan.

HOLMES: Autocrat of the Breakfast Table.

- Poet at the Breakfast Table.

- Professor at the Breakfast Table.

Elsie Venner.

HUGHES : Tom Brown's School Days.

- Tom Brown at Oxford.

VICTOR HUGO: William Shakespeare.

JEFFREY : Essays from "The Edinburgh Review." I. : English Poets and Poetry.

JOHNSON : Rasselas.

à KEMPIS : Imitation of Christ. Tr. by Benhas.

KINGLAKE : Eothen.

LAMB : Essays of Elia.

LANDOR : Imaginary Conversations. I.: Classical Dia. logues. II. : Dialogues of Sovereigns and Statesmen.

LEOPARDI: Dialogues. Tr. by JAMes Thomson.

LESSING : Laocoon. Tr. by Sir R. Phillimore.

LOWELL: My Study Windows.

MACAULAY: History of England. 5 vols.

- Historical Essays.

- Literary Essays.

MACKENZIE: The Man of Feeling, \&c.

MAINE : Ancient Law.

MARRYAT: The King's Own.

MILL: Dissertations and Discussions. I.

- Representative Government.

On Liberty.

Utilitarianism.

MORRIS (Sir Lewris) : Poems. Authorized selection.

PALGRAVE : Golden Treasury of Songs and Lyrics.

PEACOCK : Novels, 2 vols.

POE: Tales of Mystery and Imagination.

READE (Charles): Hard Cash.

REYNOLDS (Sir Joshna): Discourses to Art Students

SHAKESPEARE: Works, in 6 Vols.

SMITH (Alex.): Dreamthorp : Country Essays.

SPECTATOR (The): Edited by G. A. AITKEN. 6 vols.

STERNE: A Sentimental Journey.

SWIFT : Journal to Stella.

SYBEL : History and Literature of the Crusades.

TENNYSON : Poems.

TRELAWNY : Records of Shelley, Byron, and the

TYNDALL: The Glaciers of the Alps. [Author.

WHYTE-MELVILLE: The Gladiators.

WHITMAN (Walt): Specimen Days.

WOOD (Mrs. Henry): The Channings.

- East Lynne. 

PN 1031 M27d

L 0057231680

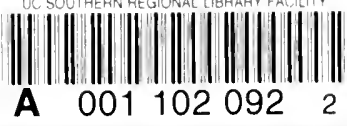




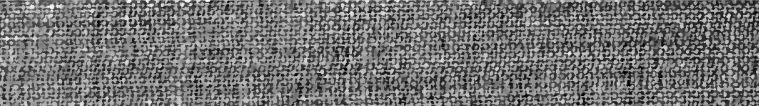

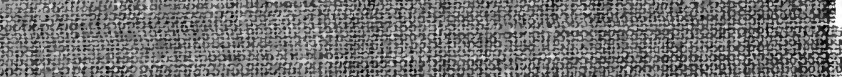

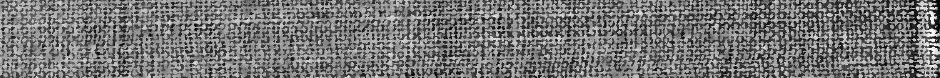

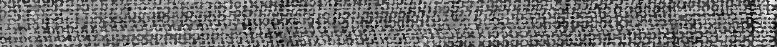

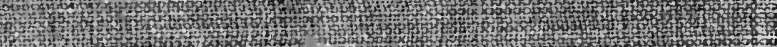
3.

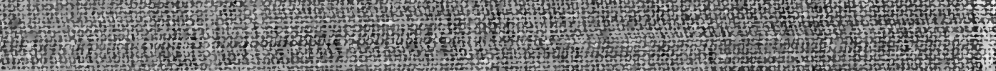
4.

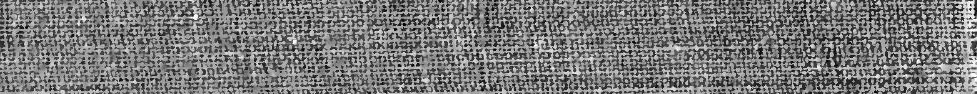

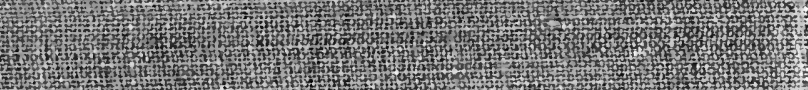
3.

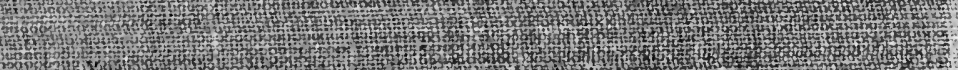

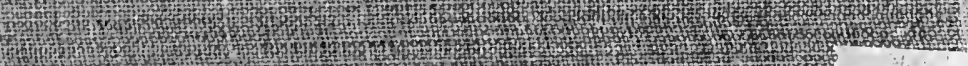

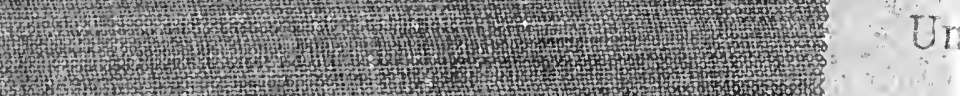

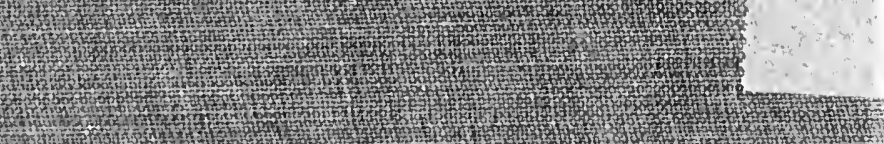

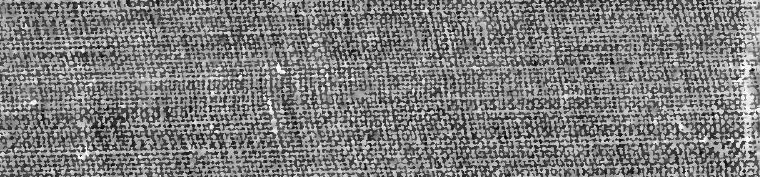

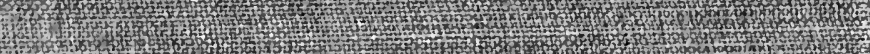

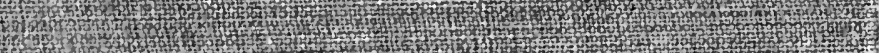

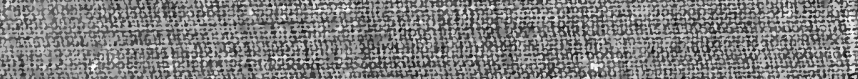

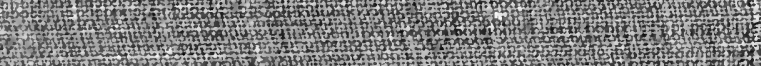
A

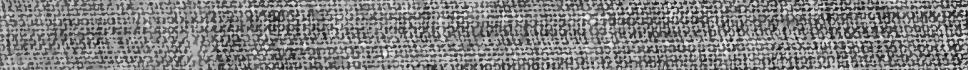
6.

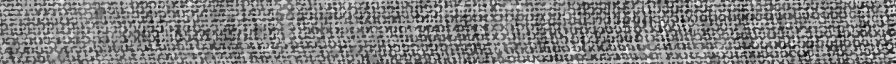
W HW

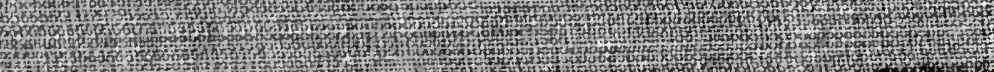

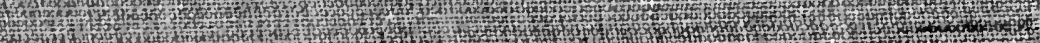
SW 